\title{
Punctuated Sediment Discharge during Early Pliocene Birth of the Colorado River: Evidence from Regional Stratigraphy, Sedimentology, and Paleontology
}

\author{
Sedimentary Geology - Invited research article
}

\author{
Rebecca J. Dorsey ${ }^{(\mathrm{a})}$, Brennan O'Connell ${ }^{(\mathrm{a})}$, Kristin McDougall ${ }^{(\mathrm{b})}$, Mindy B. Homan ${ }^{(\mathrm{a})}$ \\ (a) Dept. of Earth Sciences, University of Oregon, Eugene, OR, 97403, United States. \\ (b) U. S. Geological Survey, 2255 N. Gemini Dr., Flagstaff, AZ, 86001, United States \\ dorsey@uoregon.edu (R.J. Dorsey), brennanoconnell2@gmail.com (B. O'Connell), \\ kris@usgs.gov (K. McDougall), homanmb@miamioh.edu (M.B. Homan).
}

Article website: https://doi.org/10.1016/j.sedgeo.2017.09.018.

\begin{abstract}
The Colorado River in the southwestern U.S. provides an excellent natural laboratory for studying the origins of a continent-scale river system, because deposits that formed prior to and during river initiation are well exposed in the lower river valley and nearby basinal sink. This paper presents a synthesis of regional stratigraphy, sedimentology, and micropaleontology from the southern Bouse Formation and similar-age deposits in the western Salton Trough, which we use to interpret processes that controlled the birth and early evolution of the Colorado River. The southern Bouse Formation is divided into three laterally persistent members: basal carbonate, siliciclastic, and upper bioclastic members. Basal carbonate accumulated in a tidedominated marine embayment during a rise of relative sea level between $\sim 6.3$ and $5.4 \mathrm{Ma}$, prior to arrival of the Colorado River. The transition to green claystone records initial rapid influx of river water and its distal clay wash load into the subtidal marine embayment at $\sim 5.4-5.3 \mathrm{Ma}$. This was followed by rapid southward progradation of the Colorado River delta, establishment of the earliest through-flowing river, and deposition of river-derived turbidites in the western Salton Trough (Wind Caves paleocanyon) between $\sim 5.3$ and 5.1 Ma. Early delta progradation was followed by regional shut-down of river sand output between $\sim 5.1$ and $4.8 \mathrm{Ma}$ that resulted in deposition of marine clay in the Salton Trough, retreat of the delta, and re-flooding of the lower river valley by shallow marine water that deposited the Bouse upper bioclastic member. Resumption of sediment discharge at $\sim 4.8 \mathrm{Ma}$ drove massive progradation of fluvial-deltaic deposits back down the river valley into the northern Gulf and Salton Trough.

These results provide evidence for a discontinuous, start-stop-start history of sand output during initiation of the Colorado River that is not predicted by existing models for this system. The underlying controls on punctuated sediment discharge are assessed by comparing the depositional chronology to the record of global sea-level change. The lower Colorado River Valley and Salton Trough experienced marine transgression during a gradual fall in global sea level between $\sim 6.3$ and $5.5 \mathrm{Ma}$, implicating tectonic subsidence as the main driver of latest Miocene relative sea-level rise. A major fall of global sea level at 5.3Ma outpaced subsidence and drove regional delta progradation, earliest flushing of Colorado River sand into the northern Gulf of California, and erosion of Bouse basal carbonate and siliciclastic members. The lower Colorado River valley was re-flooded by shallow marine waters during smaller changes in global sea level $\sim 5.1-4.8 \mathrm{Ma}$, after the river first ran through it, which requires a mechanism to stop delivery of sand to the lower river valley. We propose that tectonically controlled subsidence along the lower Colorado River, upstream of the southern Bouse study area, temporarily trapped sediment and stopped delivery of sand to the lower river valley and northern Gulf of California for $\sim 200-300 \mathrm{kyr}$. Massive progradation of the fluvial-deltaic system back down the
\end{abstract}


river valley into the Salton Trough starting $\sim 4.8-4.5 \mathrm{Ma}$ apparently was driven by a huge increase in sediment discharge that overwhelmed the sediment-storage capacity of sub-basins along the lower river corridor and established the fully integrated river channel network.

\section{Introduction}

The world's large rivers are well characterized in terms of water and sediment discharge, geochemistry, and contributions to global weathering (Potter, 1978; Milliman and Meade, 1983; Meybeck, 1987; Gaillardet et al., 1999; Milliman and Farnsworth, 2011), but the processes that govern the birth and evolution of continent-scale rivers are less well understood because the stratigraphic record is often buried in deep marine basins (e.g., Figueiredo et al., 2009; Galloway et al., 2011). Controls on river integration may include changes in regional precipitation and hydrology, inherited topographic disequilibrium, and base-level changes resulting from sea-level rise or fall, epeirogenic uplift, and fault-controlled crustal deformation and tilting (Twidale, 2004; Tandon and Sinha, 2007). River catchments may grow by upwardmigrating headward erosion and stream capture in both tectonically active and stable settings, as seen in examples from southern Spain (Stokes et al., 2002), southeast Asia (Clark et al., 2004), Africa (Goudie, 2005), western Himalayas (Clift and Blusztajn, 2005), and the southeastern U.S. (Prince et al., 2011). River integration and growth can also occur by downward-propagating linkage of basins that fill and overflow with water and sediment, as documented for the Rio Grande in New Mexico (Chapin and Cather, 1994; Connell et al., 2005; Repasch et al., 2017) and Colorado River (House et al., 2008; Pearthree and House, 2014), and suggested for the Snake River in Idaho and Oregon (Van Tassell et al., 2001; Wood and Clemens, 2002).

The Colorado River in the southwestern U.S. (Fig. 1) provides an excellent natural laboratory for studying processes involved in the birth and early evolution of a large river system, because sedimentary deposits that formed prior to and during river initiation are well exposed along the lower river valley and nearby in the Salton Trough basin. Controls on river evolution can be evaluated through study of process-based sedimentology, sequence stratigraphy, age constraints, and comparison of depositional history to the isotopic record of sea-level change. Interpretation of river-forming processes is informed by model- and fieldbased insights into controls on transfer of sediment from an eroding source through a river channel network (fluvial transfer subsystem) to the depositional sink (Fig. 2; Paola et al., 1992; Paola, 2000; Castelltort and Van Den Driessche, 2003; Allen, 2008; Michael et al., 2013; Romans et al., 2016). Sediment discharge (qs) is defined as a material flux (mass/time, volume/time) that can be specified at any point along a river network from its upland source to basinal sink (e.g., Paola, 2000). Qs may increase down a river channel as a result of tributary inputs or erosion along the fluvial transfer subsystem, or it may decrease downstream in response to sediment storage in areas of subsidence and mass extraction along the transport path (Paola and Martin, 2012; Michael et al., 2013). Sediment discharge can also undergo major secular variations due to temporal changes in factors such as climate, sea level, and tectonic subsidence or uplift that govern sediment mass balance. The Colorado River south of Lake Mead (Fig. 1) occupies an $\sim 400-\mathrm{km}$ long valley that winds through a linked series of wide alluviated reaches perched on deep basins that represent potential areas of sediment storage during river development.

Despite the favorable setting, reconstructing the birth and early evolution of the Colorado River has proven difficult due to contrasting hypotheses for depositional paleoenvironments of the late Miocene to early Pliocene Bouse Formation, which contains the earliest-formed river deposits along the lower reaches of the valley. It is generally agreed that the northern Bouse Formation (Fig. 1) accumulated in a series of lakes that filled with water and sediment of the first-arriving Colorado River (Spencer and Patchett, 1997; House et al., 2008; Roskowski et al., 
2010; Spencer et al., 2013; Pearthree and House, 2014; Bright et al., 2016), but the origins of the southern Bouse Formation are debated. The two leading hypotheses for the southern Bouse (paleo-lake Blythe) propose that it formed in either: (1) a large inland lake that was isolated from the ocean, similar to the northern Bouse (Spencer and Patchett, 1997; House et al., 2008; Roskowski et al., 2010; Spencer et al., 2013; Pearthree and House, 2014; Bright et al., 2016); or (2) a marginal-marine estuary that formed by regional subsidence at the north end of the Gulf of California rift, followed by filling with sediments of the early Colorado River (Metzger, 1968; Smith, 1970; Taylor, 1983; Buising, 1988, 1990; Turak, 2000; McDougall, 2008; McDougall and Miranda-Martínez, 2014; Miller et al., 2014; O'Connell et al., 2017).

The age of the Colorado River is also in question. According to one hypothesis, the river first flowed through the southern valley sometime after $4.83 \mathrm{Ma}$, based on presence of the 4.83Ma Lawlor Tuff interbedded with Bouse carbonates at Buzzards Peak and Amboy (Fig. 1; Sarna-Wojcicki et al., 2011; Harvey, 2014), which are considered to record lake deposition prior to arrival of the through-flowing river (e.g., Spencer et al., 2013). A second hypothesis postulates that carbonate overlying the Lawlor Tuff correlates to the upper bioclastic member of the Bouse Formation that post-dates the earliest through-flowing river-channel sandstones, suggesting that the Colorado River first flowed down the valley to the ocean sometime before 4.83 Ma (Homan, 2014; Dorsey et al., 2016). Ongoing debate over these divergent hypotheses obscures our understanding of the age and origins of the Colorado River.

To address the above questions, we present a synthesis of new and previously published data on the stratigraphy, sedimentology, and paleontology of the southern Bouse Formation, south of Blythe, California, and similar-age deposits in the western Salton Trough. The data support a model in which the Colorado River first delivered sediment to the Salton Trough at about 5.3 Ma, sand output then stopped for a short time, and delivery of sand to the Salton Trough marine basin resumed starting $\sim 4.5-4.8 \mathrm{Ma}$. Processes that controlled punctuated birth of the Colorado River are inferred using estimates of paleo-sediment discharge and comparison of the depositional chronology to the isotopic record of sea-level change. We conclude that tectonic subsidence along the developing Pacific-North America plate boundary drove late Miocene marine incursion into the Salton Trough and lower river valley region, and helped establish the river's path to the ocean. Large secular fluctuations in sediment discharge were controlled by complex, poorly understood interactions among eustatic, structural, and climatic processes. These results highlight the benefit of integrating regional stratigraphy, sedimentology, and paleontology to better understand the processes that influence initiation, evolution, and long-term sediment output of large river systems.

\section{Geologic and Stratigraphic Background}

The lower Colorado River runs south through a highly deformed region from the western edge of the Colorado Plateau through the Eastern California Shear Zone to the modern San Andreas fault at the active Pacific-North America plate boundary (Fig. 1). During early to middle Miocene time, the lower Colorado River region underwent strong erosion extension, detachment faulting, exhumation of crystalline rocks, and widespread basin formation and filling that ended around 12-14 Ma (Davis and Lister, 1988; Spencer and Reynolds, 1989; Nielson and Beratan, 1990; Dorsey and Becker, 1995). Low-angle detachment faults are cut by younger, late Miocene to modern strike-slip and normal faults of the Eastern California Shear Zone (Dokka and Travis, 1990; Bartley and Glazner, 1991; Richard, 1993). The Colorado River flows through a series of inherited extensional valleys and crosses into the Salton Trough at Yuma, Arizona, where subsurface fault-bounded basins are filled with late Miocene to Holocene deposits (Olmsted et al., 1973). Southwest of Yuma, the river forms a large delta confined by active basin-bounding faults, with bifurcating distributary channels that flow northwest into the Salton Sea and southeast into the northern Gulf of California (Fig. 1). 
The Salton Trough is an active pull-apart basin that hosts a thick fill of late Cenozoic sedimentary deposits derived from the Colorado River (Fig. 1; Fuis et al., 1984; Dorsey, 2010; Schmitt and Vazquez, 2006). The Salton basin and southern San Andreas fault (SAF) were initiated $\sim 7-9 \mathrm{Ma}$ during a tectonic reorganization that localized plate boundary strain into the northern Gulf of California, initiated dextral faults in northern Mexico, and triggered the onset of rapid fault-controlled subsidence and sedimentation (Dorsey et al., 2007, 2011; Seiler et al., 2011, 2013; Bennett et al., 2013; S.E.K. Bennett et al., 2016). From late Miocene to early Pleistocene time, oblique-divergent plate motion in the Salton Trough region was accommodated by combined slip on the dextral San Andreas fault in the east and the low-angle West Salton detachment fault in the west (Axen and Fletcher, 1998; Shirvell et al., 2009). A second tectonic reorganization at $\sim 1.2 \mathrm{Ma}$ resulted in termination of slip on the detachment, initiation of the San Jacinto and Elsinore strike-slip faults, and onset of rapid uplift and inversion of western portions of the Salton Trough basin (Janecke et al., 2011; Dorsey et al., 2011, 2012).

The Fish Creek - Vallecito basin (FCVB) is a thick succession of late Miocene to Pleistocene deposits in the western Salton Trough (Fig. 1) that contains a well exposed record of late Miocene to Pleistocene sedimentation within the San Andreas fault system (Johnson et al., 1983; Dibblee, 1984; Winker, 1987; Winker and Kidwell, 1996; Dorsey et al., 2007, 2011). The 5.5-km thick basin-fill section accumulated during subsidence in the hanging wall of the West Salton detachment fault between $\sim 8.0$ and 1.2 Ma (Axen and Fletcher, 1998; Shirvell et al., 2009; Mason et al., in press). Colorado River sediment constructed a large delta that prograded into and filled the north end of the Gulf of California during early Pliocene time, when the basin was contiguous with the Salton Trough depocenter (Winker and Kidwell, 1996; Dorsey et al., 2011). The Fish Creek - Vallecito basin has been rapidly uplifted, inverted and eroded since initiation of younger strike-slip faults $\sim 1.2 \mathrm{Ma}$ (Dorsey et al., 2012).

The Bouse Formation is a late Miocene to early Pliocene sequence of carbonate and siliciclastic deposits exposed discontinuously along the lower Colorado River corridor (Figs. 1, 3 ). The southern Bouse was originally interpreted as the deposits of a marine estuary based on the common occurrence of marine to brackish-water fossils (Ross, 1923; Noble, 1931; Metzger, 1968; Smith, 1970; Metzger et al., 1973; Todd, 1976; Taylor, 1983; Winterer, 1975; Buising, 1988, 1990; McDougall, 2008; McDougall and Miranda-Martínez, 2014). Marine fossils include Colpichthys regis, a fish known from shallow and brackish waters in the Gulf of California (Todd, 1976), planktic (e.g. Streptochilus, Globigerina, Globorotalia, Turborotalia) and benthic foraminifers (e.g. Ammonia, Elphidium, Rosalina) (Smith, 1970; McDougall, 2008; McDougall and Miranda-Martínez, 2014; Miranda-Martínez et al., 2017), the intertidal gastropod Batillaria californica whose closest relative is found in the Gulf of Mexico and Caribbean Sea (Taylor, 1983), ostracodes Cyprideis and Cytheromorpha which live in coastal Gulf of California (Sandberg, 1966; Bright et al., 2016), marine bivalves Macoma and Mulinia (Metzger, 1968), calcareous red algae Sporolithon, and calcareous green algae Halimedaceae (this study).

The lake hypothesis for the Bouse Formation was introduced by Spencer and Patchett (1997), who concluded that $87 \mathrm{Sr} / 86 \mathrm{Sr}$ in basal carbonate of the Bouse Formation varies between 0.7102 and 0.7114 , significantly higher than the Sr-isotope ratio of shells in the marine Imperial Formation (0.709) and indistinguishable from the modern Colorado River. Based on Srisotope data, they concluded that the Bouse Formation accumulated in a series of inland lakes fed by the early Colorado River, and that marine faunas were introduced to the southern paleolake Blythe by birds (Spencer and Patchett, 1997). Elevation data are consistent with an expected northward increase in paleo-lake levels, including stepped increases in elevation across narrow constrictions that are interpreted as paleodams (Fig. 1; Spencer et al., 2008, 2013). Subsequent isotopic studies appear to support the lake hypothesis for the Bouse Formation (Poulson and John, 2003; Roskowski et al., 2010; Bright et al., 2016).

Stratigraphic studies document integration of the lower Colorado River by a downstreammigrating sequence of lake filling and draining events, as first-arriving waters of the Colorado 
River filled and emptied a chain of lakes by progressive north to south breaching of paleodams (House et al., 2005, 2008; Pearthree and House, 2014). Numerical simulations of river-water inflow and evaporation suggest that the northern paleolakes were very short-lived (a few kyr), and the larger southern Blythe paleolake achieved seawater-level salinities that remained stable without producing evaporites for up to $\sim 35-40 \mathrm{Kyr}$ (Spencer et al., 2008, 2013). These studies conclude that the southern paleolake Blythe, the only area where marine fossils have been found in the Bouse Formation, was thus able to support imported marine and brackish-water organisms during Bouse deposition. The lake hypothesis predicts that deposition of Bouse carbonates and siliciclastic facies, including all deposits from the northernmost paleolake to the southern paleolake Blythe (Fig. 1), took place in b50,000 years (Spencer et al., 2008, 2013).

A third, hybrid lake-estuary hypothesis postulates that the Bouse accumulated in a chain of lakes in the north that were connected to a large marine estuary (paleolake Blythe; Fig. 1) in the south (e.g., Crossey et al., 2015). In analogous modern settings, large rivers create lakes and estuaries that are linked by narrow constrictions in their lower reaches, changing from fresh water upstream to mainly marine salinities where they enter the ocean. Examples include the Krka River estuary in Croatia (Ahel et al., 1996; Cukrov et al., 2007), San Francisco Bay in California (Ingram et al., 1996, 1998), and Lake Nakaumi-Shinji in Japan (Sampei et al., 2005). The lake-estuary hypothesis is supported by evidence from paleontology, cited above, and a recent study of physical sedimentology and Fourier transform analysis that concludes that rhythmically bedded carbonate-siliciclastic deposits in the southern Bouse Formation were deposited by tidal currents in a tide-dominated marine embayment (O'Connell et al., 2017).

An important constraint on the age of the Colorado River is provided by a volcanic tuff interbedded with carbonate of the southern Bouse Formation at two localities near Amboy and Buzzards Peak, Calif. (Figs. 1, 3; Miller et al., 2014; Harvey, 2014). This tuff has been correlated using glass geochemistry to the Lawlor Tuff, which has an eruption age of $4.834 \pm 0.011 \mathrm{Ma}$ determined from 40Ar/39Ar dating of plagioclase at its type locality in northern California (SarnaWojcicki et al., 2011). Harvey (2014) found that O-isotopic data support correlation of this tuff to the Lawlor Tuff, and obtained a weighted mean age of $5.05 \pm 0.11 \mathrm{Ma}$ for $206 \mathrm{~Pb} / 238 \mathrm{U}$ zircon crystallization ages from tuff exposures at Amboy and Buzzards Peak. The zircon ages are interpreted to record crystallization in a magma chamber prior to eruption of the ash at 4.834 $\pm 0.011 \mathrm{Ma}$ (Sarna-Wojcicki et al., 2011; Harvey, 2014). Carbonate that overlies the Lawlor Tuff in these localities is generally inferred to correlate to the basal carbonate member of the southern Bouse Formation (e.g., Spencer et al., 2013; Harvey, 2014).

\section{Southern Bouse Formation}

The Bouse Formation has previously been subdivided into a basal carbonate unit, an interbedded unit of mudstone, sandstone, and siltstone, and an age-equivalent basin-margin association of tufa and conglomerate (Metzger, 1968; Buising, 1988, 1990). We refine this nomenclature and divide the southern Bouse into three informal members (Fig. 3A): (1) basal carbonate consisting of travertine, bioclastic facies, and fine-grained marl (lime mudstone); (2) siliciclastic member which includes green claystone, red mudstone and siltstone, and Colorado River cross-bedded sandstone; and (3) upper bioclastic member. The southern Bouse Formation displays systematic basinward thickening via internal stratal wedging and pinch-out geometries, with thin deposits around the margins of the basin passing laterally into thick subsurface deposits beneath the modern Colorado River floodplain (Fig. 3C; Homan, 2014; Dorsey et al., 2017).

In this section we first describe and interpret the major sedimentary lithofacies of the southern Bouse Formation (Figs. 4-7). We then present stratigraphic and micropaleontologic data from selected measured sections (Figs. 8-11), followed by a stratigraphic panel illustrating 
key aspects of basin architecture (Fig. 12) and our interpretation of regional base-level and structural controls on deposition of the Bouse Formation (Figs. 13, 14).

\subsection{Basal carbonate member}

The basal carbonate member is divided into three facies associations, or units, that occur in stratigraphic order throughout the study area (Fig. 3): (1) travertine, commonly encrusted on underlying bedrock; (2) fine- to coarse-grained bioclastic facies; and (3) fine-grained marl (Table 1 ). The base of the basal member is everywhere a sharp contact with underlying Miocene fanglomerate (alluvial fan conglomerate) or older volcanic or crystalline rocks. The basal carbonate member defines a regional transgressive systems tract, as documented below.

\subsubsection{Travertine}

Basal Bouse travertine is defined broadly here, following Crossey et al. (2017), as chemically-precipitated limestone that forms as a result of groundwater discharge at spring outlets and in lakes and streams via precipitation of calcite from waters supersaturated with respect to calcium carbonate (Ford and Pedley, 1996; Pentecost, 2005). Travertine commonly forms dense concentrically laminated carbonate rinds encrusting on underlying bedrock and conglomerate clasts. Botryoidal, columnar, and cauliflower carbonate forms large pendulous mounds and possible rimstone dam structures (Fig. 4A). Porous "tufa" includes lime mud and calc-siltite in thin to medium beds with biogenic tube casts (possibly serpulids) and rare plant imprints in a spongiform open-framework texture. We interpret travertine to be the vent and near-vent facies of an active carbonic spring system that discharged into a shallow lake or marine estuary (e.g., Pentecost, 2005; Jones and Renaut, 2010; Crossey et al., 2015). Carbonate was precipitated by off gassing of $\mathrm{CO} 2$ from cool or warm spring waters. Possible depositional environments include alkaline swamps, marshes, and/or low-energy marginalmarine lagoons (e.g. Winsor et al., 2012) near actively discharging carbonic springs, with virtually no input of siliciclastic detritus.

\subsubsection{Bioclastic Facies (Tidalites)}

Bioclastic facies in the southern Bouse Formation display a wide range of grain sizes, sedimentary structures, ratio of carbonate to siliciclastic material, and interpreted depositional processes and conditions. The major facies in this association are cross-bedded conglomerate, heterolithic facies, and bioclastic grainstone, summarized below and in Table 1.

Cross-bedded conglomerate (Fig. 4B) contains well sorted and stratified, subangular to well rounded granule-, pebble-, and cobble-size clasts in a coarse sandy calcarenitic matrix. Tabular cross-bed sets typically range from $\sim 0.2$ to $2 \mathrm{~m}$ thick, and foreset units are highly organized with inverse to normal grading and clast imbrication with clast long axes oriented both parallel and perpendicular to the transport direction. Clasts are volcanic and plutonic rocks derived from nearby sources, and include rounded travertine reworked from the underlying travertine facies. Conglomerate cross-bed sets are interbedded with and pass laterally into sandy bioclastic grainstone in bottomset and topset units. This facies records deposition in migrating beach to nearshore ridges, spits and bars in a high-energy strandline to shallow water setting. The close association of conglomerate with tidal facies (see below) indicates that gravelly bedforms were transported, reworked and segregated by strong coastal and long-shore rip currents in a tide-dominated shallow marine embayment (O'Connell et al., 2017).

Heterolithic facies contain a wide range of grain sizes and compositions including bioclastic calcarenite, silty lime mudstone, calcareous lithic sandstone, and siliciclastic siltstone and mudstone. Deposits are characterized by compositionally segregated thick-thin couplets in well sorted carbonate and siliciclastic sand, silt, and mud. Structures include horizontal laminae, sigmoidal bundles, ripple cross lamination, flaser-wavy- to lenticular bedding with mud drapes (Fig. 4C), desiccation cracks, and Thalassinoides burrows (Fig. 4D) (O'Connell et al., 2017). 
Macrofossils include abraded fragments of barnacles, small bivalves, and Batillaria gastropods. Microfossils are common to abundant in the silty or muddier intervals and are dominated by the species Buliminella elegantissima and Elphidium clavatum (Table 2). Bedding plane exposures of fine-grained lime mud (marl) in the heterolithic facies locally reveal trackways produced by camels, horses, large carnivores, and wading shorebirds (e.g., Reynolds, 2016), providing evidence of intermittent exposure in broad intertidal mud flats.

Bioclastic grainstone consists of wave-ripple laminated sandy calcarenite and coarsegrained cross-bedded barnacle-pisoidal fossil hash. Sedimentary structures include bimodalbidirectional cross bedding (Fig. 4E) and unidirectional cross-bedding with cross-bed sets 2-4 m high and up to 10's of meters long (Fig. 4F). Fossil hash contains 1-4 mm fragments of barnacles, ostracodes, bivalves, and gastropods that often are encrusted with coralline red algae to form rounded to irregular carbonate rhodolites and oncoids (Fig. 4E inset). Coarse bioclastic facies commonly pass down cross-bed foresets into finer grained heterolithic facies. Based on detailed sedimentologic analysis of sedimentary structures and facies associations, and Fourier transform analysis of layered rhythmites, O'Connell et al. (2017) showed that the bioclastic facies association was deposited by tidal currents in a tide-dominated marine setting. This interpretation is corroborated by marine foraminiferal species that record an up-section increase in water depth through the bioclastic unit into the overlying marl (see below).

\subsubsection{Fine-Grained Marl (Lime Mudstone)}

The upper unit of the basal carbonate member consists of laminated to massive lime mudstone (marl) and paper carbonate shalewith interbedded wackestone, and little or no siliciclastic clay (Fig. 4G). The marl facies lacks tidally-generated structures seen in the underlying bioclastic facies. Ostracodes and foraminifers are common to abundant in this unit, as are small bivalves and fish remains.

Sedimentary lithofacies, and biofacies summarized below, show that fine-grained marl is the culmination of a deepening-up trend observed throughout the basal carbonate member. It was deposited by slow fallout of carbonate in a quiet offshore subtidal environment free of siliciclastic input. The abrupt change from bioclastic tidalites to subtidal marl may record drowning of tidal facies as carbonate production became unable to keep pace with rising relative sea level, and/or a change in basin hydrodynamics and associated shut-down of tidal currents as the basin passed out of the tidal amplification window (O'Connell, 2016).

\subsection{Siliciclastic member}

The siliciclastic member of the southern Bouse Formation is subdivided into three main facies, or units, that occur in systematic vertical succession around the Cibola - Palo Verde Mts. area (Fig. 3B; Homan, 2014): (1) green claystone; (2) red mudstone and siltstone; and (3) thickbedded, multistorey cross-bedded Colorado River sandstone (Table 1). Together they comprise an overall coarsening- and shallowing-up succession that records earliest progradation of the Colorado river delta into a standing body of water, which we interpret was a marine estuary at the north end of the Gulf of California.

\subsubsection{Green Claystone}

The stratigraphic transition from fine-grained marl to the overlying green claystone starts with a 3-5 cm thick sharp-based green clay bed recognized as a "distinctive clay layer" (DCL) (Bright et al., 2016) seen in exposures on both sides of the Colorado River in the study area (Fig. 3B). The DCL clay layer is overlain by a $\sim 0.5-1.0 \mathrm{~m}$ thick interval of interbedded thin lime mudstone and green claystone beds (Bright et al., 2016) or a more uniform interval of weakly laminated pale green calcareous claystone (Fig. 5A). In some locations the transition is up to $\sim 3.5 \mathrm{~m}$ thick. This facies consists of massive to laminated, dark olive-green siliciclastic claystone and calcareous claystone that locally contains thin beds of fine-grained marl (lime 
mud). Veins of secondary gypsum are commonly observed in the green claystone facies. Ostracodes and foraminifers are also common in this unit.

\subsubsection{Red Mudstone and Siltstone}

Green claystone is overlain by massive to weakly bedded, reddish siliciclastic mudstone interbedded with tabular, thin to medium beds of horizontally stratified pale orange siltstone. This facies locally contains beds of green claystone, fist-sized geodes with large calcite crystals, and broadly channelized cross-bedded Colorado River sandstone. Where interbedded with cross-bedded sandstone, this facies commonly includes weak paleosols identified by the presence of drab-haloed root traces (rhizoliths) and sand-filled desiccation cracks (Fig. 5B). Sedimentary structures indicative of tidal processes, such as segregated thin-thick couplets or flaser-wavy bedding with mud drapes, are notably lacking.

We interpret red mudstone and siltstone to be the deposits of the Colorado River delta as it prograded southward into a standing body of water represented by the older carbonate and claystone facies. This conclusion is similar to that of previous workers (Buising, 1988, 1990; Pearthree and House, 2014), though the paleoenvironment of the receiving body of water (lake vs. marine) is debated (e.g. Bright et al., 2016; O'Connell et al., 2017). Broadly channelized cross-bedded sandstone bodies represent terminal distributary channels, and tabular-bedded silt and fine sand accumulated in channel-mouth bars of a low-gradient delta front system (e.g., Olariu and Bhattacharya, 2006; Ahmed et al., 2014). Desiccation cracks and weak paleosols provide evidence for intermittent subaerial exposure in mudflats of the prograding Colorado River delta plain. Aggradation in migrating low-relief bars on the delta plain produced short-lived surface exposures that led to formation of weak calcic soils. Absence of tidal sedimentary structures indicates this was a low-energy fluvial-dominated delta system.

\subsubsection{Cross-Bedded Colorado River Sandstone}

This facies contains abundant thick-bedded, multistorey, trough cross-bedded sandstone with minor interbedded mudstone in vertical exposures up to $17 \mathrm{~m}$ thick (Fig. 5C, D). Sandstone cross-bed sets are 1 to $3 \mathrm{~m}$ high and fill nested aggradational troughs and erosional channels, and some channels are filled with mudstone (Fig. 5D). Sedimentary structures include trough and tabular cross-bedding, upper planebed lamination, climbing-ripple cross lamination, and locally abundant convolute bedding with liquefaction features. Well sorted and rounded fine to medium-grained sand contains abundant quartz with distinctive hematite coatings, syntaxial quartz overgrowths, and detrital-zircon age spectra diagnostic of a Colorado River source (Buising, 1990; J. Spencer, personal comm. 2014; Kimbrough et al., 2015).

The distinctive sedimentary structures and architecture of cross-bedded sandstone indicate that it accumulated in channels of a large river system (Bridge and Diemer, 1983; Reading, 1986; Miall, 1996; Martinsen et al., 1999; Holbrook, 2001). This facies thus records deposition in the earliest through-flowing Colorado River. Concave-up bounding surfaces and nested channel scours (Fig. 5C, D) record cutand- fill episodes that result from fluctuations in river water discharge: erosional surfaces are cut during high discharge (floods) and crossbedded sand bodies are deposited as a traction load during subsequent waning flow (e.g., Holbrook, 2001). Mud-filled channels represent small oxbow lakes formed by channel avulsion and abandonment. Because the cross-bedded sandstone facies is not incised into units older than red mudstone and siltstone, we infer that it accumulated in response to increased sediment supply during a rise or still-stand of relative sea level, and thus records a classic "normal regression" (e.g., Posamentier et al., 1992; Catuneanu et al., 2009).

\subsection{Upper bioclastic member}

The upper bioclastic member of the southern Bouse Formation overlies cross-bedded Colorado-River sandstone and older units of the Bouse Formation along a regional unconformity 
that is identified for the first time here (Fig. 3; Homan, 2014; Dorsey et al., 2016; this study). This is a complex, mixed carbonate-siliciclastic facies association with a wide range of grain sizes, sedimentary structures, ratio of carbonate to siliciclastic material, and depositional processes. The finest-grained facies is mud-cracked lime mud (Fig. 6A), which to date has only been documented in western Milpitas Wash and the Buzzards Peak area. Other, more common facies of this member include fine-grained, wave ripple-laminated sandy calcarenite with abundant barnacle and mollusk fragments (Fig. 6B), pebbly calcarenite with flat-based convexup gravelly wave-formed ripple cross-bedding (Fig. 6C-E), and calcarenitic-matrix conglomerate with rounded to well rounded clasts derived from nearby catchments (Fig. 6F). Colorado River derived red mudstone is interbedded with well sorted wave-rippled grainstone in the basal $\sim 0.5-$ $1.0 \mathrm{~m}$ of the upper bioclastic member southeast of Cibola, where it rests on a regional unconformity characterized by $\sim 0.5$ - to $1 \mathrm{~m}$-deep deep karst fissures in underlying basal carbonate. Siliciclastic sandstone and siltstone beneath the unconformity do not contain any intercalated or mixed bioclastic carbonate material (Dorsey et al., 2017).

The upper bioclastic member is characterized by the common occurrence of branching calcareous green algae Halimedaceae, typically preserved as subrounded pebble- to cobblesize clasts (Fig. $7 \mathrm{~A}-\mathrm{C}$ ). Halimeda are absent in the Bouse basal carbonate member, and in contrast are common in the upper bioclastic member. We identify Halimeda based on diagnostic features including the branching segmented thallus with a singular holdfast at the base (Fig. 7C), and petrographic textures that reveal loosely packed filaments in the interiormedulla of the thallus, densely packed cortex surrounding the medulla, and thin outer coating (utricles) (Fig. 7D). Other fossils include barnacles, gastropods, bivalves (Polymesoda, Mulinia,Macoma; A. Hendy, written comm., 2015), and coralline red algae Sporolithon commonly preserved as rhodoliths encrusted on small pebbles and fossil fragments. Fine-grained calcarenite locally includes high concentrations of bivalves (Fig. 7E) that represent in-situ communities, not shells reworked from older deposits. The co-occurrence of calcareous red and green marine algae, mollusks, and barnacles defines a heterozoan association that is commonly found in subtropical shelves (James, 1997) and is well documented from the Pliocene to modern Gulf of California (e.g., Foster et al., 1997; Halfar et al., 2004, 2006). Foraminiferal assemblages are dominated by Ammonia beccarii, with rare specimens of Rosalina columbiensis, and are mostly worn and broken siliceous casts with a sugary appearance indicative of reworking.

The abundance of water-lain sedimentary structures, local concentrations of fragile bivalves, and high carbonate content inmost facies all indicate that the upper bioclastic member was deposited in a shallow, carbonate-producing high-energy water body. We infer this was a shallow marine embayment based on the common occurrence of marine fossils Halimeda green algae, Macoma bivalves, and Sporolithon coralline red algae. Wave-formed gravelly ripples (Fig. $6 \mathrm{C}-\mathrm{E}$ ) are well documented in modern and ancient high-energy marine shelf systems, and form during storm events in $\sim 2$ to $30 \mathrm{~m}$ water depth (Leckie and Walker, 1982; Hirschaut and Dingler, 1982; Leithold and Bourgeois, 1984; DeCelles, 1987; Leckie, 1988; Murray and Thieler, 2004; Cummings et al., 2009). These distinctive bedforms require deposition under water, and cannot be produced by deposition on subaerial alluvial fans. Some carbonate likely is derived from reworking of older Bouse carbonates, but reworking alone cannot produce the high carbonate content observed in most facies of this unit. An up-section increase in wave-ripple wavelength in the basal $\sim 3-5$ mof some sections (e.g., Fig. 6E) records increasing water depth during deposition of the lower part of this member. The presence of round-stone conglomerate in the vertical and lateral transition to alluvial fan conglomerate around the margins of the basin (Fig. $6 \mathrm{~F}$ ) records progradation of locally-sourced shelf-type (shoal water) fan deltas around the margins of the basin (e.g., Ethridge and Wescott, 1984; Nemec, 1990). Wave-ripple laminated calcarenite requires subaqueous deposition in shallow water, and mud-cracked lime mudstone records intermittent shallow floods alternating with subaerial exposure on large low-energy carbonate mud flats. The lateral change to fine-grained calcarenite and mud-cracked lime mud 
in Milpitas Wash also provides important sedimentologic support for our proposed correlation of the upper bioclastic member to Bouse carbonate deposits in the Buzzards Peak area (Fig. 3).

\subsection{Stratigraphic data and micropaleontology}

The southern Bouse Formation displays a wedge architecture defined by systematic thickening of stratal units toward the basin center and thinning toward basin margins (Fig. 3). The siliciclastic member thickens into the subsurface beneath the modern Colorado River west of Cibola (Fig. 3), where it includes N52 m of green claystone that is inferred to overlie the basal carbonate (the base was not penetrated here) and is overlain by $\sim 40 \mathrm{~m}$ of coarse to fine sand with minor gravel (Metzger et al., 1973). In thicker, more complete sections, the basal carbonate member fines up from bioclastic facies to fine-grained marl overlain by green claystone, red mudstone, and thick cross-bedded Colorado River channel sandstone of the siliciclastic member. The siliciclastic member pinches out on both sides of the Colorado River into areas where the upper bioclastic member rests unconformably on the basal carbonate member. Basinward thickening and wedge geometries provide evidence for broad regional tilting toward the basin center - beneath the modern Colorado River - during deposition of basal carbonate and siliciclastic members (Homan, 2014; Dorsey et al., 2017).

\subsubsection{Cibola Area}

The composite Hart Mine Wash section southeast of Cibola (Fig. 8A) reveals a vertical succession that is typical of thicker sections in the southern Bouse region. Here, a basal cobble lag with subrounded travertine clasts is overlain by thin lower marl of the basal carbonate member, about 8 mof bioclastic facies, 9mof fine-grained subtidal marl, and $5 \mathrm{~m}$ of green claystone in the lower part of the siliciclastic member. Green claystone passes up section into red mudstone and siltstone overlain by thick, multistorey, trough cross-bedded Colorado-River channel sandstone (Figs. 5C, D, 8A). Green claystone pinches out to Big Fault Wash where Colorado River sandstone and siltstone rest directly on marl of the basal carbonate member (Fig. 8B). East of there, Colorado- River sandstone pinches out to Section A5 (Fig. 8C) where the upper bioclastic member rests unconformably on marl that contains up to 1-m deep distinctive karst-dissolution fissures directly beneath the unconformity.

Five foraminiferal biofacies are recognized in the southern Bouse Formation based on the dominant species that indicate distinct environmental parameters (Table 2). Foraminiferal assemblages in the bioclastic unit include Buliminella and Elphidium biofacies (Fig. 8D). The Buliminella biofacies has low abundance and is found primarily in thin fine-grained intervals between coarser fossil hash layers, often interfingering with the Elphidiumbiofacies. This biofacies is usually limited to single samples in the southeastern part of the Blythe Basin (Marl Wash, HartMineWash, and Big FaultWash) and is not well documented. The Buliminella biofacies records shallow marine deposition in wave-dominated environments, at shallow inner neritic depths of $7 \mathrm{~m}$ or less (Table 2; e.g.,Walton, 1955; Bandy, 1961; Phleger, 1964; Smith, 1964; Ingle, 1980). The Elphidium biofacies contains an abundant and more diverse foraminiferal assemblage dominated by Elphidium clavatum(Fig. 8D). This biofacies suggests water depths increased to approximately $20 \mathrm{~m}$ depth, a well-oxygenated water mass, and salinities that are normal to slightly brackish and seasonal (Sen Gupta et al., 1996; Cope and Herrmann, 2004; Eichler et al., 2012). Diversity increases up section, reflecting increased environmental stability and water depths. The assemblage may include Buliminella elegantissima. Other species such as Ammonia beccarii, Cibicides fletcheri, Bolivina pacifica, and Rosalina columbiensis appear (Fig. 8D), indicating increased water depth.

Foraminifers in the upper marl of the basal carbonate member are assigned to the Rosalina and Streptochilus biofacies (Table 2; Fig. 8D), and suggest a continued increase in water depth through time. The Rosalina biofacies indicates inner neritic water depths, possibly as deep as $50 \mathrm{~m}$. This biofacies contains an abundant and diverse assemblage similar to the 
Elphidium biofacies but dominated by Rosalina columbiensis, Neoconorbina terquemi, Patellina corrugata, and/or Spirilina vivipara. The upper depth limit of $R$. columbiensis is near the inner/outer neritic biofacies boundary $(50 \mathrm{~m})$. This species is commonly attached to sea grasses, marine plants, carapaces, chitons, drifting wood, shells, and pebbles (Smith, 1964; Delaca and Lipps, 1972; Lankford and Phleger, 1973; Dobson and Haynes, 1973; Langer, 1993). Rare planktic foraminifers, Globorotalia and Turborotalia, occur near the base of the uppermarl unit in the Rosalina biofacies indicating a connectionwith the proto-Gulf that was deep enough to allow these organisms to enter the Blythe Basin (McDougall and MirandaMartínez, 2014). The Streptochilus biofacies suggests a further increase in water depth (Table 2): the foraminiferal assemblage is similar to that found in the Elphidium and Rosalina biofacies except for the change in dominance to Streptochilus. Streptochilus is an opportunistic planktic foraminifer that appears in shallow surface water $(75-150 \mathrm{~m})$ in tropical to subtropical coastal regions where fluctuating nutrient-richwater is upwelled resulting in relatively eutrophic conditions (Resig and Kroopnick, 1983; Hemleben et al., 1989; Nikolaev et al., 1998; Smart and Thomas, 2006, 2007; Ohtsuka et al., 2015; Schiebel and Hemleben, 2005). The absence of new species in this biofacies despite increased water depths suggests that the connection to the proto-Gulf of California may have been restricted.

Foraminifers in the basal part of the green claystone, just above the DCL, represent the Streptochilus biofacies, whereas the assemblages in the remainder of the green claystone represent the Ammonia biofacies (Fig. 8D). In both the marl and claystone, foraminiferal assemblages and marginal marine ostracodes above the DCL decline in abundance from that found in the underlying marls, and they are interspersed with samples that contain only nonmarine ostracodes (Candona). The Ammonia biofacies is a monospecific assemblage composed entirely of Ammonia beccarii. This species has an upper depth limit in the inner neritic biofacies, can tolerate abrupt salinity changes, is common in both hypo- and hypersaline conditions, and thrives where it lacks competition (Arnal, 1961; Phleger, 1964; Smith, 1964; Ingle, 1980; Culver and Buzas, 1986; Burone et al., 2013). Salinity during deposition of the green claystone may have been low, as juveniles are absent from the assemblages and reproduction ceases below salinities of $\leq 150 / 00$ (Bradshaw, 1957). The number of test abnormalities increases up section, indicating variations in salinity or temperature (Arnal, 1955; Resig, 1974; Cann and de Dekker, 1981; Almogi-Labin et al., 1992; Stouff et al., 1999). Occasionally in this unit, a single foraminiferal sample contains a more abundant and diverse assemblage, similar to Streptochilus or Rosalina biofacies. These samples are usually found in muddier sediment and are interpreted as material reworked from the underlying marl. Foraminifers in the upper bioclastic member are dominated by Ammonia beccarii, with few to rare specimens of Rosalina columbiensis. All foraminifers in the upper bioclastic member occur as abraded and broken siliceous casts with a sugary texture that indicates considerable reworking. No original calcite tests are preserved in this assemblage. Reworked silica casts record a history of burial diagenesis followed by erosion of the basal carbonate member, then deposition of the upper bioclastic member in a carbonate-producing shallow body of water (see above), suggesting significant changes in relative sea level through time.

The age of the Bouse Formation in Hart Mine Wash is based on the presence of Globorotalia lenguaensis in the lower part of the upper marl unit (Fig. 8A; sample Mf11682 in McDougall and Miranda- Martínez, 2014) and several species of Streptochilus (MirandaMartínez et al., 2017). Globorotalia lenguaensis suggests an age no younger than $6.0 \mathrm{Ma}$, the time when this species became extinct in the Equatorial Pacific Ocean (Wade et al., 2011). The last occurrence datum (LOD) of Streptochilus latus (range: 8.1 to 5.3Ma in the Equatorial Pacific Ocean; Resig, 1989, 1993) and S. mcdougallae (local range: 6.0 to $5.3 \mathrm{Ma}$ in the Gulf of California; Miranda-Martínez et al., 2017) occurs in the basal part of the green claystone and therefore indicates an age no younger than 5.3 Ma. Detrital sanidine from the DCL in Hart Mine Wash, stratigraphically below the LODs of planktic foraminifers listed above, yielded one 40Ar- 
39Ar age of $5.0 \pm 0.4 \mathrm{Ma}$ (Crow et al., 2016; pers. comm., 2016), consistent with our age interpretation based on the foraminifers.

\subsubsection{Palo Verde Mountains and Western Milpitas Wash}

In the southeast Palo Verde Mountains, cross-bedded conglomerate and bioclastic facies of the Bouse basal carbonate member are overlain by green claystone, red mudstone and siltstone, and channelized trough cross-bedded Colorado-River sandstone (Fig. 9). Colorado River sandstone is erosionally overlain by $\sim 7 \mathrm{~m}$ of upper bioclastic member with flat-based convex-up gravelly wave-formed ripple bedforms that record an up-section increase in water depth (Fig. 6E). In western Milpitas Wash the upper bioclastic member rests unconformably on fine-grained marl of the basal carbonate member, which contains $0.5-1.0$ mdeep karst fissures and a 6-12 cm thick karst-breccia horizon beneath the unconformity (Fig. 10). Marl of the basal carbonate member thins to the west from $\sim 5.5 \mathrm{~m}$ in section $\mathrm{C} 13$ to $\sim 30 \mathrm{~cm}$ in section $\mathrm{C} 27$.

The upper bioclastic member is recognized in these sections based on its unique stratigraphic position on older Bouse units, basal unconformity, dissolution fissures in underlying marl, and common occurrence of distinctive Halimeda fragments (Fig. 10). The upper bioclastic member in the westernmost section (C27) contains fine-grained calcarenite with in-situ bivalve concentrations (Fig. 7E) and locally developed bedding-plane desiccation cracks in lime mud (Fig. 6A) that represent a low-energy carbonate mud-flat facies not observed in the Cibola area. The upper bioclastic member at section C27 overlies a discontinuous 10- to 15-cm thick gray ash bed that may correlate to the Lawlor Tuff near Buzzards peak. Westward thinning of marl in this area is likely due to erosional truncation and thinning toward the basin margin.

Foraminifers are common to abundant in sections in Milpitas Wash (Fig. 10B) whereas no foraminifers have been recovered from the Paleo Verde Mountain sections. Only the Elphidium biofacies is recognized in bioclastic facies of the basal carbonate member, and Elphidium, Rosalina, and Streptochilus biofacies are all represented in the upper marl. Only the Streptochilus biofacies is recognized in the lower part of the green claystone. The Ammonia biofacies is present in the green claystone and the upper bioclastic unit but this biofacies is not well developed in Milpitas Wash. In general, preservation of the microfossils in the Milpitas Wash and Palo Verde Mountain sections is poor. Preservation of specimens in the upper bioclastic unit is particularly poor and again suggests reworking.

\subsubsection{Buzzards Peak Area}

In section BP1 near Buzzards Peak (Fig. 3B), fine-grained carbonate of the Bouse Formation rests on a volcanic ash bed identified as the 4.83-Ma Lawlor Tuff based on tephrochronology (Sarna-Wojcicki et al., 2011) and U-Pb dating and O-isotopes of zircon (Harvey, 2014) (Fig. 11). Here, Bouse carbonate consists of fine-grained thin-bedded micrite and calcarenite with small-scale wave-ripple bedding that grades up-section into massive tufa with thick calcified reed mats and tube casts. At section BP2 to the east, a similar undated meter-thick gray ash bed, which likely correlates to the Lawlor Tuff, is interbedded with variably silicified thin-bedded calcarenite and micrite with desiccation cracks, reed mats, and tufa, similar to carbonate facies in section BP1 (Fig. 11). Based on westward lateral fining and similar facies in the upper bioclastic member in Milpitas Wash, we suggest that fine-grained carbonate near Buzzards Peak correlates to the upper bioclastic member. Samples of carbonate from the Buzzards Peak sections were examined for microfossils. The residues are barren of organics, appear to be heavily weathered, and tend to have a reddish cast. Many grains are encrusted with secondary calcite. Correlation to other Bouse sections is not possible based on residues.

\subsection{Synthesis and interpretation, southern Bouse Formation}

The stratigraphic panel in Fig. 12 illustrates key aspects of stratigraphic architecture in the southern Bouse Formation. The base of the upper bioclastic member provides a useful datum 
for correlating measured sections because it is a widespread thin unit that accumulated in shallow water over a short period of time. We integrate this stratigraphic framework with information from process sedimentology and micropaleontology to interpret sequence stratigraphy and base-level changes during deposition of the Bouse Formation (Fig. 13). These results inform our reconstruction of basin geometries and evolution of depositional environments (Fig. 14).

The basal carbonate member of the southern Bouse Formation defines a transgressive systems tract that accumulated during a rise in relative sea level and flooding of the lower Colorado River valley with marine water (Figs. 13, 14A). Diffuse strain in a system of linked dextral and oblique-normal faults resulted in broad syn-depositional subsidence, sagging, and tilting toward the axis of a N-S trending depocenter along the future path of the Colorado River, and in an adjacent E-W trending depocenter in future Milpitas Wash (Homan, 2014; Dorsey et al., 2017). Former terrestrial valleys were transformed by relative sea-level rise to a high-energy tide-dominated shallow marine embayment (O'Connell et al., 2017). The abrupt change to subtidal marl records drowning of a mixed carbonate-siliciclastic platform and/or a reduction in tidal range during a relative sea-level rise that caused the basin to pass out of the tidal amplification window (e.g., Stanzo and Boer, 1995; O'Connell, 2016).

The transition from subtidal marl to green claystone records the end of clear-water carbonate deposition due to rapid introduction of the most distal wash-load clay fraction of Colorado River-derived sediment. Mixing of marine and freshwater faunas in the lower part of the green claystone unit likely records rapid hydrological changes that resulted from rapid new influx of Colorado River water into a marine setting. Similar mixing of faunas occurred at the end of Younger Dryas period, when catastrophic floods drained glacial Lake Agassiz into the St. Lawrence Estuary (Cronin et al., 2012). This change in the southern Bouse Formation was previously interpreted as a record of catastrophic flooding in a saline lake that was isolated from the ocean (Bright et al., 2016). Based on data presented above, we conclude that green claystone instead records suspension settling in a subtidal marine embayment or saline lake that had a connection to the sea during the earliest arrival of Colorado River water and sediment.

The up-section transition through red mudstone and siltstone to multistorey trough crossbedded Colorado River channel sandstones records progradation of the Colorado River delta and arrival of the earliest through-flowing Colorado River by latest Miocene time (Fig. 14B; Buising, 1990). Diagnostic sedimentary structures and fluvial architecture of cross-bedded sandstone record deposition in channels of an integrated regional river system (e.g., Bridge and Diemer, 1983; Reading, 1986; Miall, 1996; Martinsen et al., 1999; Holbrook, 2001). Because the cross-bedded fluvial channel sandstone is not incised into units older than red mudstone and siltstone, it appears the delta prograded southward in response to increased sediment supply during a rise or highstand of relative sea-level (Fig. 13), suggestive of a normal regression (e.g., Posamentier et al., 1992; Posamentier and Allen, 1999; Catuneanu et al., 2009, 2011).

Around the margins of the basin the upper bioclastic member rests directly on basal carbonate on a regional unconformity that cuts out older siliciclastic deposits (Fig. 12). We do not know how much sediment was removed by erosion beneath this contact, since much of the westward thinning of the siliciclastic member likely is due to nondeposition outside of the main subsiding depocenter. Karst fissures and breccia beneath the unconformity record subaerial exposure and carbonate dissolution during a relative sea-level lowstand (e.g., Meng et al., 1997; Booler and Tucker, 2002). Silica casts of microfossils in the upper bioclastic member likely formed by precipitation of silica into internal void spaces during burial diagenesis of older Bouse carbonate deposits. Calcite tests were removed by dissolution during the same phase of diagenesis. Possible sources of silica include remobilization from volcanic ash, clay minerals, hydrothermal groundwater, and meteoric water. Subaerial exposure may have created intake areas for circulation of silica-rich meteoric waters into the subsurface, a process that is 
commonly invoked to explain silicification and karst features beneath unconformities in other carbonate successions (Meyers, 1977; Young et al., 2012). The silica casts were later exhumed during erosion that formed the unconformity, and reworked into the upper bioclastic member.

A key finding of this study is that the upper bioclastic member is a water-lain deposit that records re-flooding of the lower Colorado River valley by a standing body of water after the Colorado River first ran through it (Figs. 12, 14C). Sedimentary structures documented in this unit require deposition under water (Fig. 6), and cannot form in a subaerial alluvial fan environment. Microfossil silica casts and some carbonate material are derived from reworking of older Bouse units, but reworking alone cannot produce the high carbonate content, mudcracked micrite, local bivalve concentrations, or first appearance of marine green algae Halimedaceae. We favor a marine environment for this unit based on the abundance and cooccurrence of calcareous red algae Sporolithon, green algae Halimeda, and marine mollusks and barnacles that define a heterozoan faunal association common in subtropical shelves (James, 1997) and Gulf of California (Foster et al., 1997; Halfar et al., 2004, 2006). Red mudstone locally interbedded with well sorted calcarenite in the lower 0.5-1.0 $\mathrm{m}$ of the upper bioclastic member is interpreted to be reworked from underlying floodplain fines that were remobilized and redeposited as thin palimpsest deposits during reflooding of the valley. The reflooding phase ended with rapid progradation of alluvial fans around the margins of the southern Bouse depocenter, followed by deposition of the Bullhead Alluvium in 18 R.J. Dorsey et al. I Sedimentary Geology 363 (2018) 1-33 a rejuvenated through-flowing Colorado River starting 4.5-4.8 Ma (Fig. 14D; Howard et al., 2015).

The upper bioclastic member displays an important lateral change from coarse sandy and pebbly calcarenite in the Palo Verde Mountains and Cibola area to low-energy fine-grained calcarenite and lime mud with mud cracks and clam beds in western Milpitas Wash (Figs. 3B, 12). Based on this lateral change and regional stratigraphic relations, we propose that finegrained carbonate of the upper bioclastic member in Milpitas Wash correlates to similar finegrained carbonate that overlies Lawlor Tuff near Buzzards Peak (Fig. 12). This correlation is further suggested by the presence of a thin undated gray ash bed beneath the upper bioclastic member in section C27 (Fig. 10A), which may be an erosional remnant of the Lawlor Tuff.

\section{Western Salton Trough}

\subsection{Stratigraphic summary}

The lower $\sim 2500$ mof the Fish Creek - Vallecito basin in the western Salton Trough (Fig. 15) provides a high-fidelity record of deposition prior to, during, and after initiation of the Colorado River. Depositional ages are known from paleomagnetic data constrained by dated volcanic tuffs high in the section and biostratigraphy in the lower part (Dorsey et al., 2007, 2011; McDougall, 2008; this study). Sedimentation began at $\sim 8.0$ Ma with fault-controlled deposition of the late Miocene Elephant Trees Conglomerate, which consists of alluvial fan deposits capped by a subaerial large rock-avalanche megabreccia (Kerr and Abbott, 1996; Winker and Kidwell, 1996; Abbott et al., 2002; Shirvell, 2006). The lower megabreccia is overlain by the Fish Creek Gypsum and locally-sourced turbidites of the Latrania Formation (Lycium Member), which record marine incursion into the Salton Trough region $\sim 6.3 \mathrm{Ma}$ (Fig. 15A; Dorsey et al., 2007, 2011; McDougall, 2008). Lycium Member turbidites are overlain by a second megabreccia that was emplaced catastrophically into a marine basin (Kerr and Abbott, 1996; Abbott et al., 2002) immediately prior to the end of the Miocene epoch (Fig. 15).

The lower $\sim 20 \mathrm{~m}$ of Wind Caves member consists of thin- to medium-bedded turbidites that contain angular to subangular quartz, feldspar, and detrital biotite sourced from nearby plutonic rocks (Fig. 16), and a detrital-zircon population dominated by Cretaceous and Jurassic ages (Fig. 15B; Kimbrough et al., 2015). About $20 \mathrm{~m}$ above the base of the Wind Caves member there is an abrupt change to thick-bedded, normally graded and channelized sand-rich 
turbidites (Fig. 17A) composed of Colorado River-derived sandstones dominated by moderately to well rounded quartz with lesser feldspar and lithic fragments including chert and metavolcanics (Fig. 16). Quartz grains commonly exhibit syntaxial quartz overgrowths and hematite coatings indicative of a source on the Colorado Plateau (e.g., Winker, 1987; Buising, 1990). Colorado River-derived detrital zircons have a complex distribution of ages with prominent peaks at $1700 \mathrm{Ma}, 1400 \mathrm{Ma}, 1100 \mathrm{Ma}$, and multiple smaller peaks between 600 and $30 \mathrm{Ma}$, similar to detrital zircon ages of early Pliocene Colorado River sands exposed along the lower Colorado River (Fig. 15B; Kimbrough et al., 2015; Cloos, 2014). Reworked Cretaceous foraminifers derived from the Colorado Plateau are common in mudstones near the base of the Wind Caves member, first appearing at the same level as the oldest Colorado River-derived sandstones, and persist up-section through the Coyote Clay and Mud Hills member (A.Y. Miranda-Martínez, personal communication, 2017). The base of the Thvera subchron (5.24 Ma) is defined by a change from reversed to normal magnetic polarity in the upper part of the Wind Caves member, consistent with placement of the Miocene-Pliocene boundary (5.33 Ma) near the base of the Wind Caves member (Dorsey et al., 2007, 2011, this study). The upper half of the Wind Caves member displays a gradual up-section change to thin-bedded turbidites and a decrease in sandstone bed thickness, grain size, and sand:mud ratio. The upper $\sim 20 \mathrm{~m}$ consists of mud-dominated, thin-bedded Colorado River-derived turbidites in the transition to the Coyote Clay unit (Fig. 16).

Coyote Clay is defined here as an informal sub-member, $\sim 5.1$ to $4.8 \mathrm{Ma}$, that makes up the lower $\sim$ third of the Mud Hills member of the Deguynos Formation in the Fish Creek section (Figs. 15, 17B). This is a widespread unit of greenish yellow-weathering marine claystone with rare thin silt laminae, also known as "Coyote Mountain Clays" (Hanna, 1926), that is observed over large areas of the Salton Trough and Coachella Valley to the northern Indio Hills (Fig. 1; Winker, 1987; Hanna, 1926; Jefferson and Lindsay, 2006). In many locations around the western Salton Trough, over a NW-SE distance of $\sim 50 \mathrm{~km}$ from Borrego Mountain in the NW to the Coyote Mountains in the SE, the Wind Caves member is absent and Coyote Clay rests directly on older sedimentary, volcanic, and crystalline bedrock units that pre-date the Wind Caves member (Winker, 1987; Steely, 2006). Coyote Clay is overlain by silt-sand marine rhythmites of the upper Mud Hills Member (Fig. 17B), which coarsen up-section and are overlain by fossiliferous marine sandstone and mudstone of the Yuha and Camels Head Members of the Deguynos Formation. The top of the Deguynos Formation is a conformable transition to Colorado River cross-bedded channel sandstones and mudstone floodplain deposits of the Arroyo Diablo Formation (Fig. 17C).

\subsection{Micropaleontology and biostratigraphy}

Turbidites of the Lycium Member contain a distinctly inner neritic benthic foraminiferal assemblage composed of several species of Textularia (Fig. 15C). Reworked specimens of Amphistegina gibbosa appear in clasts of the upper megabreccia and in the lowest samples of the overlying Wind Caves Member. This species is thought to last appear in the Imperial Group in the latest Miocene (Ingle, 1974; McDougall et al., 1999; Dorsey et al., 2007; McDougall, 2008), indicating that the megabreccia and Wind Caves Member are $\geq 5.3 \mathrm{Ma}$. Foraminiferal assemblages in the Wind Caves Member are diverse and abundant and document an abrupt environmental change. The assemblages indicate that deposition occurred in upper bathyal conditions, and based on the abundance of Bolivina interjuncta, suggest deposition in a low oxygen water mass that is typically found in the upper bathyal biofacies at depths of approximately $300 \mathrm{~m}$. The low-oxygen conditions may be due in part to an influx of water from the Blythe Basin, as low-oxygen conditions are suggested by the increase of Streptochilus near the boundary between marl and green claystone in the Bouse Formation ( 5.3-5.4 Ma). The dominance of low-oxygen species continues through the Wind Caves Member. Foraminiferal assemblages in the Coyote Clay unit of the Mud Hills Member are dominated by species with 
upper depth limits in the outer neritic biofacies, probably near the shelf slope break $(\sim 150 \mathrm{~m})$, and thus suggest a decrease in water depth. Species diagnostic of the oxygen-minimum zone and the upper bathyal biofacies in the lower part of the Coyote Clay unit become less abundant or are absent from assemblages in the upper Coyote Clay. Similar depths are indicated for siltsand marine rhythmites of the upper Mud Hills Member. The percentage of inner neritic species increases in the youngest samples of this unit indicate decreasing water depths (Fig. 15C).

Marine deposits in Split Mountain Gorge are late Miocene to early Pliocene age. The Miocene-Pliocene boundary (5.33 Ma) is placed at the first occurrence datum (FOD) of Pliocene species Streptochilus globigerus, Turborotalia anfracta, and Globigerina multiloba, and the last occurrence datum (LOD) of late Miocene Amphistegina gibbosa near the base of the Wind Caves Member of the Latrania Formation (Fig. 15A; A.Y. Miranda-Martínez, personal communication, 2017). This age assignment is consistent with independently determined correlation of magnetic reversals to the geomagnetic polarity timescale (Dorsey et al., 2007, 2011). Amphistegina gibbosa became extinct in the northern Gulf and Salton Trough region at approximately 5.3 Ma (Ingle, 1974; McDougall et al., 1999; Dorsey et al., 2007, 2011; McDougall, 2008). The first occurrence of $\mathrm{T}$. anfracta is $5.8 \mathrm{Ma}$, the range of S. globigerus in the equatorial Pacific is 5.45 to $3.6 \mathrm{Ma}$, and the range of $\mathrm{G}$. multiloba is Miocene to Pliocene (Blow, 1979; Resig, 1989, 1993; Miranda-Martínez et al., 2017; A.Y.Miranda- Martínez, personal communication, 2017). The highest occurrence of S. globigerus in this section is slightly below the highest occurrence of Globoturborotalita decoraperta, which has a LOD in the western equatorial Pacific at 2.2 Ma (Chaisson and Leckie, 1993). Based on these first and last appearances, the Lycium Member is late Miocene in age. The Wind Caves and Mud Hills Members up to the middle of Coyote Clay are assigned to planktic zone PL1 (equivalent to N18N19), which ranges from 5.7 to $4.4 \mathrm{Ma}$ (Blow, 1979; Wade et al., 2011; Gradstein et al., 2012). Planktic foraminifers above this level are not diagnostic of age.

\subsection{Paleo-sediment discharge}

We can estimate sediment discharge from the Colorado River during earliest Pliocene time using the dimensions and age of the Wind Caves member, which filled a paleocanyon $\sim 10$ $\mathrm{km}$ wide to a maximum thickness of $\sim 100 \mathrm{~m}$ that thins to zero at paleocanyon margins (Fig. 16; Winker, 1987; Cloos, 2014). The Wind Caves member also pinches out to zero thickness in the down-transport direction b10-15 km south of Split Mountain Gorge (Winker, 1987; BykerkKauffman, 2017), placing a useful constraint on the volume of river-derived sediment that accumulated in the offshore sink during deposition of this unit. Combining these dimensions with a paleogeographic reconstruction that restores post-depositional relative plate motion (Fig. $19 \mathrm{~B}$ ), the original length of the paleocanyon at $5.3 \mathrm{Ma}$ is about $130 \mathrm{~km}$. Assuming a triangular cross-section geometry, $\sim 50 \%$ post-depositional compaction, and dimensions listed above, we estimate an original volume of about $150 \mathrm{~km} 3$ for the early Pliocene paleocanyon fill. Adding ca. $250 \mathrm{~km} 3$ to account for similar-age deposits in the subsurface in the Yuma area (Olmsted et al., 1973; their Plate 10, unit Tt), we estimate that roughly $300-500 \mathrm{~km} 3$ of sand (including original porosity, average density $2000 \mathrm{~kg} / \mathrm{m} 3$ ) accumulated in the basin during deposition of the Wind Caves paleocanyon. Dividing this volume by the duration of deposition ( 0.1-0.2 Myr) suggests an average sediment flux of roughly $1500-5000 \mathrm{~km} 3 / \mathrm{Myr}$, equivalent to a mass flux of about 3$10 \mathrm{Mt} . / \mathrm{yr}$, much less than the long-term geologic average for the Colorado River (150-200 Mt./yr; Dorsey and Lazear, 2013). Averaged over the river catchment area on the Colorado Plateau $(371,000 \mathrm{~km} 2)$, the volumetric sediment flux suggests erosion rates of $\sim 4-14 \mathrm{~m} / \mathrm{Myr}$ between $\sim 5.3$ and $5.1 \mathrm{Ma}$, or $\sim 6-20 \mathrm{~m} / \mathrm{Myr}$ if the Green River catchment $(116,200 \mathrm{~km} 2)$ is excluded. These estimates overlap with 10Be-based paleoerosion rates of $\sim 10-40 \mathrm{~m} / \mathrm{Myr}$ determined for the early Pliocene Colorado River by Matmon et al. (2012). Despite uncertainties in the calculations, this exercise shows that early Pliocene sediment discharge was much slower than the long term geologic average. 


\subsection{Stratigraphic synthesis, western Salton Trough}

Data presented above confirm the first appearance of Colorado River sand near the base of the Wind Caves member at ca. 5.3 Ma (Figs. 15, 16). Thick-bedded sandstones of the Wind Caves member record deposition by sand-rich turbidity currents in a submarine canyon that was fed by early Pliocene input from the Colorado River (Winker, 1987; Dorsey et al., 2007, 2011; Kimbrough et al., 2015; Cloos, 2014). Colorado River-derived turbidites of the Wind Caves member are restricted to an $\sim 10-\mathrm{km}$ wide paleocanyon, and pinch out over b10- $15 \mathrm{~km}$ in the down-transport direction to the Coyote Mountains where the Wind Caves member is absent and the Coyote Clay rests directly on older deposits (Winker, 1987; Bykerk-Kauffman, 2017). The location of the Wind Caves paleocanyon coincides with an anomalously thick, expanded section of latest Miocene to early Pliocene coarse- Fig. 17. Field photos of sedimentary rocks in the Fish Creek - Vallectio basin. A. Channelized sand-rich turbidites in the Wind Caves member of the Latrania Formation. B. Gently dipping interval from upper part of Wind Caves member through Coyote Clay unit of Mud Hills member, to lower part of Yuha member marine deltaic succession. C. Large-scale cross-bedded Colorado River channel sandstones and overbank mudstones of the Arroyo Diablo Formation. 22 R.J. Dorsey et al. / Sedimentary Geology 363 (2018) 1-33 grained deposits that formed in a fault-bounded sub-basin in the Split Mountain Gorge area (Winker, 1987; Winker and Kidwell, 1996; Shirvell, 2006). Thick deposits in this area are thus the consequence of localized late Miocene subsidence and rapid basin filling that started $\sim 8.0 \pm 0.4 \mathrm{Ma}$ (Shirvell, 2006; Dorsey et al., 2011).

In contrast to the restricted distribution of the Wind Caves member, the Coyote Clay unit records deposition of marine clays over a large area during regional shut-down of sand input to the basin. One study proposed that Coyote Clay accumulated on the marine slope of the Colorado River delta as it prograded steadily southward over base-of-slope submarine fans of the Wind Caves member, with no interruption of sediment input or delta progradation (Cloos, 2014). This hypothesis predicts that Coyote Clay should be limited to the area of the delta slope, and that turbidites of the Wind Caves member extend farther into the basin than the Coyote Clay. These predictions are contradicted by map and stratigraphic data that show the opposite relationship: Coyote Clay is a widespread marine claystone that accumulated over a large region of the Salton Trough, whereas sandy turbidites of the Wind Caves member are restricted to a relatively narrow paleocanyon in the Split Mountain Gorge area (Winker, 1987; Shirvell, 2006; Bykerk-Kauffman, 2017). We therefore conclude that Coyote Clay records shut-down of sand delivery from the Colorado River to the northern Gulf of California for a short time between $\sim 5.1$ and 4.8Ma (Fig. 15). The inferred shallowing of paleo-water depth from the Wind Caves member to Coyote Clay may record subtle uplift in this part of the basin during termination of slip on faults that controlled localized deposition of theWind Caves member.

Starting $\sim 4.8 \mathrm{Ma}$, resumption of sand input from the Colorado River resulted in upward shallowing and coarsening of the upper Mud Hills, Yuha, and Camels Head members of the Deguynos Formation (Fig. 15). Progradation of the Colorado River delta took place during an abrupt increase in basin subsidence rate and culminated in arrival of fluvial deposits of the Arroyo Diablo Formation at $\sim 4.25 \mathrm{Ma}$ (Dorsey et al., 2011). The strongly progradational behavior of the Colorado River delta during a period of accelerated and sustained rapid subsidence, which otherwise would be expected to cause delta retreat and backstepping, provides evidence for a supply-driven delta system that overwhelmed the effects of basin subsidence with very high sediment flux from the river (e.g., Goodbred and Kuehl, 2000; Carvajal and Steel, 2006). This conclusion is consistent with sediment mass-balance calculations that document a large sustained flux of sediment from the Colorado River to actively subsiding plate-boundary basins over the past ca. 5-6 Myr (Dorsey, 2010; Dorsey and Lazear, 2013). 


\section{Regional Synthesis}

Based on results presented above, we correlate late Miocene to early Pliocene deposits in the Fish Creek - Vallecito basin to deposits of the lower Colorado River valley, Whitewater Canyon, and Fortuna Basin in the Yuma area (Figs. 1, 18). Deposition of the southern Bouse Formation spanned about $1.5 \mathrm{Myr}$, from $\sim 6.3$ to $4.8 \mathrm{Ma}$. This chronology differs from previous interpretations that the Bouse Formation accumulated in b50,000 years (Spencer et al., 2013) during the time window defined by analytical uncertainty of plagioclase 40Ar-39Ar ages in the Lawlor Tuff of northern California (4.834 $\pm 0.011 \mathrm{Ma}$; Sarna-Wojcicki et al., 2011). Our data do not support such a short duration for Bouse deposition. We instead document a depositional history that includes a protracted rise in relative sea level starting $\sim 6.3 \mathrm{Ma}$, arrival of the earliest through-flowing Colorado River at $\sim 5.4-5.3 \mathrm{Ma}$, a regional unconformity that produced karstdissolution features on the Bouse basal carbonate member, and a temporary hiatus in river sediment output during deposition of the upper bioclastic member ( 5.1 to $4.8 \mathrm{Ma}$ ).

Fig. 19 shows four paleogeographic reconstructions of the lower Colorado River valley and Salton Trough region during initiation and early evolution of the Colorado River from 6.3 to 4.0Ma. The reconstructions include incremental adjustments for latest Miocene to early Pliocene translation of the Pacific plate relative to North America (S.E. Bennett et al., 2016). Our data show that the basal carbonate member of the southern Bouse Formation formed in a marine embayment at the north end of the Gulf of California during regional marine incursion that flooded the northern Gulf and Salton Trough to the Parker area starting 6.5-6.3 Ma (Fig. 19A; Oskin and Stock, 2003; Dorsey et al., 2011). The marine Imperial Formation accumulated in the Whitewater Canyon area (San Gorgonio Pass) near the northwest margin of the seaway between $\sim 6.3$ and 5.5 Ma (Fig. 18; McDougall et al., 1999; McDougall, 2008). Imperial Formation marine deposits in the northern Indio Hills (Dibblee, 1997) may have formed during initial marine incursion, and/or early Pliocene time (Winker, 1987). A rise in relative sea level caused deepening-up from intertidal to subtidal conditions over a large area from Parker, Ariz., south to Cibola and Milpitas Wash, possibly inundating areas a far west as Amboy in a tideswept shallow marine embayment or saline lakes (Miller et al., 2014). Areas north of Parker may have experienced carbonate deposition in one or more lakes during this period (House et al., 2008; Pearthree and House, 2014), though the timing of deposition in the northern lakes remains uncertain. The width and location of the marine connection from the Cibola-Milpitas area south to the Salton Trough is not well known due to lack of stratigraphic control in that area, but a passage through the Buzzards Peak area is plausible based on evidence for broad post- Bouse uplift and erosion along the Chocolate Mountains anticlinorium (Beard et al., 2016).

The stratigraphic transition from marl of the Bouse basal carbonate member to green claystone of the siliciclastic member records earliest introduction of fine-grained clay from the Colorado River to the southern Bouse marine embayment at ca. 5.4-5.3 Ma (Figs. 8, 18). This was followed by rapid southward progradation of the Colorado River delta and establishment of a through-flowing Colorado River in the lower river valley, represented by trough cross-bedded sandstone of the Bouse siliciclastic member, starting 5.3 Ma (Fig. 19B). The river transported sediment south to the Salton Trough and initiated deposition of sand-rich marine turbidites in the Wind Caves paleocanyon in the northern Gulf of California. Routing of turbidity currents along the west margin of the Salton Trough likely resulted from fault-controlled subsidence and tilting of the basin floor toward the breakaway of the West Salton detachment fault.

Fig. 19C depicts regional shut-down of sand output from the Colorado River to the northern Gulf of California that lasted for $\sim 200-300 \mathrm{kyr}$ between $\sim 5.1$ and $4.8 \mathrm{Ma}$. Fluvial channel and floodplain environments were inundated by high-energy shallow marine waters that deposited a diverse suite of mixed carbonate-siliciclastic facies in the upper bioclastic member of the southern Bouse Formation, south of Blythe. The Colorado River delta retreated to the north as sediment supply decreased, possibly stalling in the Blythe to Parker area (Fig. 19C). In 
the northern Gulf of California (present-day Salton Trough), the Wind Caves paleocanyon became inactive as the supply of sand diminished, producing the transition from the upper Wind Caves member to Coyote Clay (Figs. 15, 16). Outside the area of the paleocanyon, Coyote Clay was deposited on older sedimentary, volcanic, and crystalline bedrock units over a large area of the western Salton Trough (Winker and Kidwell, 1996; Bykerk-Kauffman, 2017). The hiatus ended when sand output by the Colorado River resumed, depositing Bullhead Alluvium in the lower river valley and building the river delta southward into the northern Gulf of California (Fig. 19D; Dorsey et al., 2011; Howard et al., 2015).

\section{Discussion}

\subsection{Depositional paleoenvironments of the southern Bouse Formation}

We conclude from data presented above that the southern Bouse Formation accumulated in a large late Miocene marine embayment R.J. Dorsey et al. / Sedimentary Geology 363 (2018) 1-33 23 that was linked to the Gulf of California oblique rift in the south, and possibly to a chain of lakes in the north (Fig. 20A). Other studies have proposed that the southern Bouse formed in a large inland lake isolated from the sea by a paleodam in the southern Chocolate Mountains (Fig. 20B; e.g., Spencer and Patchett, 1997). The inland-lake hypothesis has gained support fromstudies of carbonate geochemistry, $\mathrm{Sr}$ isotopes, $\mathrm{C}$ and $\mathrm{O}$ isotopes, stratigraphy, and hydrologicmodels (e.g., Poulson and John, 2003; House et al., 2008; Roskowski et al., 2010; Spencer et al., 2008, 2013; Pearthree and House, 2014; Bright et al., 2016).We suggest that some of these datasets should be reevaluated in light of new constraints presented in this paper. The marine-embayment hypothesis (this study) is supported by multiple lines of evidence including micro- and macro-paleontology, $\mathrm{Sr}, \mathrm{O}$, and $\mathrm{C}$ isotopes, chemical mixing models, process sedimentology, and Fourier transform analysis of tidal rhythmites (Table 3 ). While it is beyond the scope of this paper to fully analyze or reconcile all existing datasets, below we explore several topics that are central to this debate.

The inland-lake hypothesis for the Bouse Formation was originally based on a finding that $87 \mathrm{Sr} / 86 \mathrm{Sr}$ ratios in Bouse limestone $(0.7102$ to 0.7114$)$ are higher than the expected ratio for marine carbonate $(0.7090)$ and indistinguishable from the modern Colorado River (0.7108) (Spencer and Patchett, 1997). However, subsequent studies have shown that $87 \mathrm{Sr} / 86 \mathrm{Sr}$ ratios of Bouse carbonates are actually higher and more variable $(0.7101-0.7123)$ than modern water of the lower Colorado River (0.7100-0.7101) (Roskowski et al., 2010; Crossey et al., 2015). Sr isotopes in Bouse carbonates thus record complex mixing of multiple poorly understood inputs. Crossey et al. (2015) found that the maximum Bouse Sr-isotope ratios in each sub-basin (Fig. 1) decrease southward by $\sim 0.0003$ per basin, suggesting a southward increase in low-87Sr/86Sr waters consistent with a seawater contribution in the south. They documented an inverse correlation between $87 \mathrm{Sr} / 86 \mathrm{Sr}$ ratio and [Sr] concentration, and showed that southern Bouse carbonates occupy an intermediate field along a mixing trend between high-87Sr/86Sr, low-[Sr] carbonate of the Hualapai Limestone in the north, and low-87Sr/86Sr, high-[Sr] carbonate of the marine Imperial Formation in the south. The range and variability of Bouse Sr isotopes can be reproduced by mixing river and marine waters with only $1-8 \%$ radiogenic groundwater, which means Sr values slightly more radiogenic than seawater do not preclude a marine influence in the southern Bouse Formation (Crossey et al., 2015). In addition, trace-metal systems such as $\mathrm{Sr}$ in carbonates are highly susceptible to alteration by diagenesis and other post-depositional processes (Brand and Veizer, 1980), but the potential for post-depositional changes in Bouse Sr isotopes has not been fully evaluated. Recent U/Th analysis reveals evidence for open-system isotopic behavior in Bouse carbonates (Crow et al., 2016), suggesting a need for caution when using $\mathrm{Sr}$ isotopes to interpret original water chemistry and paleoenvironments of the Bouse Formation. The inland-lake hypothesis explains the presence of abundant marine and brackishwater faunas in the southern Bouse Formation by avian transport (introduction by birds), a 
process that is known to occur globally (e.g., Spencer and Patchett, 1997; and references therein). Many of the marine species in the Bouse Formation have been documented from coastal lagoons and salt lakes located at or near sea level, with or without a direct connection to the ocean (e.g., Bandy, 1961; Horton, 1999; Javaux and Scott, 2003; Issa, 2010). However, we are not aware of any modern or ancient analogue in which an abundant, moderately diverse assemblage of planktic and benthic marine organisms similar to that of the Bouse Formation was introduced to a large inland saline lake by birds, and reproduced in large numbers to successfully colonize the lake. This poses a significant challenge to the inland-lake hypothesis for the southern Bouse Formation.

A recent study of stable isotopes and ostracodes from the Bouse Formation in Hart Mine Wash (Fig. 8A; Bright et al., 2016) concluded that marl of the basal carbonate was deposited in a stratified saline lake, and that lake waters became less saline and well mixed after deposition of the distinctive clay layer (DCL). This interpretation was based on: (1) strongly negative $\mathbf{\delta} 180$ values and a wide range of $\delta 13 \mathrm{C}$; (2) offset of stable-isotope values between carbonate matrix and ostracodes in the marl unit, and a change to uniform values above the DCL; (3) cooccurrence of fresh-water, brackish, and marine organisms; and (4) similarity of isotopic values in fresh- and brackish-water ostracodes. These results are at odds with other studies that document co-variation of southern Bouse stable isotopes in mollusk shells and marl along a mixing trend from isotopically light $(\delta 13 \mathrm{C}=-4 ; \delta 18 \mathrm{O}=-8)$ to seawater values $(\delta 13 \mathrm{C}=+1$; $\delta 180=0$ ) (Roskowski et al., 2010; Crossey et al., 2015). Inconsistent results from different studies suggest a need to standardize sample preparation methods, which may influence interpretation of water chemistry and recognition of primary carbonate versus secondary cements and clay contamination. Our data show that fresh-water, brackish, and marine organisms occur together only in the $\sim 1-m$ thick interval above the DCL, coinciding with an abrupt onetime change from clear-water carbonate deposition to arrival of rive-derived green clays at the base of the siliciclastic member.

The presence of planktic marine species Globorotalia lenguaensis (LOD $\geq 6.0 \mathrm{Ma}$ ) near the base of the upper marl unit indicates that the travertine and bioclastic units of the southern Bouse Formation are $\geq 6.0 \mathrm{Ma}$. Age constraints in the Hualapai Limestone show that water and sediment of the Colorado River first arrived in the Lake Mead area sometime after $5.97 \pm 0.07$ Ma (Spencer et al., 2001; Crossey et al., 2015). Thus it appears that travertine and bioclastic facies of the southern Bouse basal carbonate member pre-date arrival of the Colorado River in the lower river corridor, and likely did not accumulate in a lake filled with Colorado River water. Based on sediment composition and stratigraphic relations, we infer that the upper marl unit of the basal carbonate member also predates arrival of river water and sediment. The transition from marl to green claystone is thus interpreted to record rapid initial influx of Colorado River water and its clay wash load into a pre-existing marine embayment at $~ 5.4-5.3 \mathrm{Ma}$, which effectively shut off the carbonate factory at that time.

Our interpretation of a marine environment for the southern Bouse basal carbonate member is corroborated by process sedimentology (O'Connell et al., 2017). Observations that support deposition in a tidal setting include: (1) abundant tidal sedimentary structures such as flaser and wavy bedding, lateral relationships, and vertically stacked tidal facies assemblages; (2) distinctive sigmoidal bundle sequences and nonrandom bundle patterns; (3) remarkable continuity, sorting, and lithological segregation of thin-thick couplets; and (4) Fourier analysis of rhythmite successions that record daily and neap-spring tidal cyclicity (O'Connell et al., 2017). While some of the observed structures are rarely found in lacustrine environments, deposition by lake currents produces non-cyclic layering due to random variations in flow velocity and direction (Ainsworth et al., 2012). The strongly cyclic thickness variations and regular lithologic alternations observed in the southern Bouse Formation cannot not be produced by non-tidal processes such as river floods, wind-generated lake currents, storms, or biochemical varve deposition (De Boer et al., 1989; Dalrymple and Choi, 2007; Ainsworth et al., 2012). 
In summary, we conclude that multiple lines of evidence support the marine-embayment hypothesis for the southern Bouse Formation. A marine origin for the southern Bouse Formation requires up to $\sim 330$ muplift of the lower Colorado River corridor in the past $\sim 5 \mathrm{Myr}$, suggesting slow long-term uplift rates of b0.1 mm/yr.

\subsection{Southern Bouse upper bioclastic member}

Sedimentologic data presented above show that the upper bioclastic member of the southern Bouse Formation was formed by subaqueous depositional processes in a large, carbonate-producing shallow body of water. Observations that support this conclusion (Figs. 6 , 7 ) include: (1) high carbonate content $\gg 50 \%$ and $>50 \%$ in lime mud, sandy calcarenite, and calcarenitic-matrix conglomerate facies; (2) first appearance and common occurrence of the distinctive branching green algae Halimeda, which we have not observed in the basal carbonate member; (3) abundant water-lain sedimentary structures such as symmetrical wave-ripple cross-lamination in sandy calcarenite; (4) common occurrence of long wave-length gravelly wave-formed ripple cross-bedding, a common product of storm waves on high energy coarsegrained shelves (e.g. Clifton, 1986;DeCelles, 1987); (5) preservation of articulated thin-shelled mollusks that could not survive erosional reworking and abrasion; and (6) desiccation cracks in fine-grained lime mudstone that record intermittent flooding and drying in low-energy carbonate mud flats. An alternative hypothesis postulates that the upper bioclastic member formed by subaerial reworking and redeposition of older carbonate material eroded from the basal carbonate member in alluvial fans around the margins of a draining, falling lake, during deposition of the Bouse siliciclastic member (Gootee et al., 2016). We disagree with this interpretation because an alluvial-fan setting cannot explain the observations and data listed above.

The alternative hypothesis includes lateral interfingering and age equivalence of the Bouse upper bioclastic member and the middle siliciclastic member, with the basal contact described as conformable at higher elevations and unconformable at lower elevations (Gootee et al., 2016). Our data do not support this prediction. We have documented evidence for a regional unconformity at the base of the upper bioclastic member that everywhere truncates and postdates all older units of the Bouse Formation. These contrasting interpretations reflect, in part, different ideas about the origin of thin red mudstone interbeds in the lower $\sim 1.0$ mof the upper bioclastic member southeast of Cibola, where it rests on an unconformable contact with deep karst fissures formed on subtidal marl facies of the Bouse basal carbonate member (e.g., Fig. $8 \mathrm{C})$. As noted above, the red mudstone interbeds are best interpreted as palimpsest deposits reworked from older floodplain muds of the earliest through-flowing Colorado River, and do not indicate a conformable relationship at this or other locations where the contact is well exposed. The unconformity at the base of the upper bioclastic member records a period of nondeposition, erosion, and exposure of older Bouse deposits that likely formed during the final stages of a large fall in eustatic sea level that drove initial flushing of Colorado River sand down the valley to the Gulf of California between $\sim 5.3-5.2 \mathrm{Ma}$ (Fig. 21). For reasons summarized above, we therefore conclude that the upper bioclastic member records re-flooding of the southern Colorado River valley by a shallow standing body of water after the river first ran through it (Fig. 19C).

\subsection{Age of the Colorado River and southern Bouse Formation}

Previous studies inferred that the Colorado River post-dates the 4.83-Ma Lawlor Tuff, because the tuff is overlain by limestone that was assumed to correlate to Bouse basal carbonate (e.g., Spencer et al., 2013; Harvey, 2014). Until recently there was no reason to question this assumption because the known Bouse Formation included only a thin basal carbonate, an interbedded siliciclastic unit, and age-equivalent travertine (e.g., Metzger, 1968; Buising, 1990). Recognition of the Bouse upper bioclastic member above an unconformity in the 
lower Colorado River valley places an important new constraint on the regional chronology and age of the Colorado River. Our proposed correlation of carbonate near Buzzards Peak to the upper bioclastic member is equally as plausible as the traditional model, it is supported by an important lateral facies change to fine-grained lime mud and calcarenite in western Milpitas Wash sections (Figs. 10-12), and it reconciles the stratigraphic records of the southern Bouse Formation and western Salton Trough. New biostratigraphy and recognition of a regional unconformity at the base of the upper bioclastic member (this study) require much more time for deposition than was assumed in previous studies. The presence of at least two magnetic polarity reversals in the southern Bouse Formation (Howard et al., 2016) indicates that Bouse deposition lasted for at least $100 \mathrm{kyr}$ and likely much longer. Our proposed regional chronology (Fig. 18) is consistent with a biostratigraphically derived age estimate of $\sim 5.4-5.3 \mathrm{Ma}$ for the base of green claystone in the Cibola area (Fig. 21) and well constrained age of earliest Colorado River-derived sandstones in the western Salton Trough (Fig. 15A).

Depositional ages in the Fish Creek - Vallecito basin, Salton Trough, are known from integrated biostratigraphy, paleomagnetism, and $\mathrm{U}-\mathrm{Pb}$ dating of two tuffs high in the section (Fig. 15A; Dorsey et al., 2007, 2011; this study). Our preferred correlation to the GPTS is the only one that yields a reasonable chronology in which sediment accumulation rates vary gradually through thick stratigraphic intervals and are constant across multiple magnetic reversals of irregular duration (Dorsey et al., 2011). Other correlations were considered and rejected because they introduce extremely large, geologically unreasonable excursions in sedimentation rate that correspond to magnetic reversals (Dorsey et al., 2011, their Fig. 11). Cloos (2014) suggested a younger depositional age based on U-Pb (laser ablation ICP-MS) ages of single detrital zircon grains in four samples from the Wind Caves and Mud Hills members. Although youngest single-grain detrital zircon ages provide potential insight into depositional ages, this approach is limited because: (1) the inherent lack of reproducibility limits reliability because individual ages may be spurious due to lead loss (Dickinson and Gehrels, 2009; Gehrels, 2012); (2) the first problem is exacerbated in this setting because the accuracy of U-Pb ICPMS ages in young (Pliocene) zircon is highly sensitive to the correction for common lead (e.g., Horstwood et al., 2003); and (3) magnetic reversals are closely spaced in time for this part of the geomagnetic polarity timescale (Fig. 15A), and therefore high-precision dating (TIMS) of detrital zircon grains would be required to perform a meaningful test of depositional ages in this section.

The regional correlations in Fig. 18 establish for the first time a fully consistent chronology that integrates depositional histories and existing age constraints for the lower Colorado River and Salton Trough region. While these results confirm a ca. 5.3 Ma age for integration of the Colorado River to the ocean, they raise new questions about regional processes that controlled punctuated sediment discharge during initiation and early evolution of this river system.

\subsection{Controls on punctuated sediment discharge}

A discontinuous, start-stop history of sand output during initiation of the Colorado River contradicts expectations that a large river should maintain an active channel, even where it flows across bedrock obstacles, because of the erosional effects of a large sediment load (e.g., Sklar and Dietrich, 2004; Turowski et al., 2007). However, competing processes such as sealevel rise, basin subsidence, and related sediment storage are capable of shutting down river sand discharge and driving regional retreat, or backstepping of large delta systems at geologic timescales (Swenson et al., 2000; Cattaneo and Steel, 2003; Catuneanu et al., 2009; Romans et al., 2016). Data presented above provide abundant evidence for punctuated sediment discharge during river initiation, so the question becomes: how and why did sand output from the Colorado River turn on, off, and on again in a $\sim 1$ million-year interval between $\sim 5.4$ and 4.4 Ma? 
We address this question by comparing our depositional chronology to the history of global sea-level change between 7 and 4 Ma (Fig. 21; Miller et al., 2005; Lisiecki and Raymo, 2005; Raymo et al., 2009; Miller et al., 2011). The lower Colorado River valley and Salton Trough region were flooded by a marine transgression and rise of relative sea level during an overall fall in global sea level between 6.3 and $5.5 \mathrm{Ma}$ (Fig. 21). The apparent contradiction of rising relative sea-level during a fall in global sea level, prior to input of sediment from the Colorado River, can be explained by fault-controlled subsidence in transtensional basins along and adjacent to the Pacific-North America plate boundary that started ca. 7-8 Ma (Dorsey et al., 2011; Bennett et al., 2015; S.E.K. Bennett et al., 2016). A global sea-level lowstand at $5.75 \mathrm{Ma}$ may have contributed to the hiatus below the upper megabreccia (UMB) in the FCVB section, though deposits of the same age elsewhere in the Salton Trough do not display the same hiatus (McDougall, 2008), suggesting that this unconformity had a local structural control. The rise of global sea level at $\sim 5.5 \mathrm{Ma}$ may have accentuated deepening trends in the lower Colorado River valley (upper marl unit of the Bouse basal carbonate member).

We therefore conclude that tectonic subsidence along the Pacific- North America plate boundary was the main driver of relative sea-level rise in the lower Colorado River valley and Salton Trough region from $\sim 6.5$ to $5.4 \mathrm{Ma}$ (Fig. 19A). Subsidence was accommodated by basinward tilting and sagging along the future trace of the Colorado River (Homan, 2014; Dorsey et al., 2017), and was related to diffuse transtensional strain in a zone of late Miocene dextral and oblique-normal faults that connected the Eastern California Shear Zone in SE California to the Gulf of California shear zone in the northern Gulf of California (Fig. 1; Bennett et al., 2013; S.E.K. Bennett et al., 2016). Like S.E. Bennett et al. (2016), we postulate that late Miocene subsidence inboard of the evolving plate boundary drove lowering of the landscape and exerted an important tectonic control on the path of the first-arriving Colorado River when it emerged by lake spillover from the Colorado Plateau (House et al., 2008; Pearthree and House, 2014).

Comparison to the global sea-level curve shows that initial delta progradation and earliest delivery of Colorado River sand to the Salton Trough took place during a major fall in eustatic sea level from 5.3 to $5.2 \mathrm{Ma}$ (Fig. 21). The identical timing of these two events suggests that global sea-level fall drove earliest flushing of river sediment to the deep marine basin in the northern Gulf of California. This interpretation has to be reconciled with the absence of an unconformity at the base of river channel sandstone in the Bouse siliciclastic member (Figs. 12, 13), which suggests the earliest Colorado River delta prograded during a rise or highstand of relative sea level. We infer Fig. 21. Comparison of chronostratigraphy from 7 to $4 \mathrm{Ma}$ in the Salton Trough and lower Colorado River valley to the global eustatic sea-level curve (Miller et al., 2011). The comparison provides powerful insights into controls on base-level change and sediment discharge during initiation and early evolution of the Colorado River. See text for discussion. 28 R.J. Dorsey et al. / Sedimentary Geology 363 (2018) 1-33 that an initial large pulse of river sediment input forced aggradation in the lower river valley, even as global sealevel lowering drove progradation of the delta into the Salton Trough at $\sim 5.3 \mathrm{Ma}$ (Fig. 21 ; c.f., Catuneanu et al., 2011). The unconformity at the base of the upper bioclastic member is interpreted as the record of continued base-level lowering that was driven by the same eustatic fall. We conclude that an early strong pulse of Colorado River sediment flux was sufficient to cause river aggradation during initial stages of eustatic fall, and that the unconformity at the base of the upper bioclastic member formed as the ultimate consequence of a major global sealevel lowstand at $\sim 5.2 \mathrm{Ma}$ (Fig. 21).

Initial flushing of river sand into the offshore marine basin was followed by shutdown of sand output from the Colorado River to the northern Gulf of California for 200-300 kyr, between $\sim 5.1$ and 4.8 Ma. This resulted in deposition of Coyote Clay in the sand-starved Salton Trough, and upper bioclastic member of the Bouse Formation in the lower Colorado River valley, during regional retreat and backstepping of the delta (Figs. 18, 19C). Comparison to the eustatic curve 
shows that re-flooding of the lower Colorado River valley occurred during continued but slower fall in global sea level (Fig. 21), and requires a mechanism to stop delivery of sand to the lower river valley for $\sim 200-300 \mathrm{kyr}$.We suggest that transtensional strain along the lower Colorado River corridor between Lake Mead and Parker (Fig. 1) and/or in the Parker-Blythe region (Fig. 19C) drove subsidence in one or more pull-apart basins, trapping sediment and temporarily stopping the supply of sand to the southernmost river valley and northern Gulf of California. A 3-kmdeep sedimentary basin beneath the Mohave Valley (Fig. 1; Saltus and Jachens, 1995) could have stored Colorado River sand during a period of rapid local subsidence and accumulation, though the age of subsurface deposits in this area is not well known. Thick subsurface deposits of Bouse Formation siliciclastic sediments in the Parker-Blythe region (Metzger et al., 1973) represent other potential areas of sediment storage during the short-lived hiatus in river sand discharge.

Sediment output resumed at $\sim 4.8-4.5 \mathrm{Ma}$, as recorded in the transition from prodelta Coyote Clay to marine sand-silt rhythmites in the Fish Creek - Vallecito basin (Figs. 15A, 18, 20). This was followed by aggradation of Bullhead Alluvium in the lower Colorado River valley (Howard et al., 2015) and progradation of the delta into the Salton Trough that culminated in arrival of fluvial deposits in the western Salton Trough by $\sim 4.25 \mathrm{Ma}$ (Figs. 15A, 19D). Strong progradation of the Colorado River delta took place during a rise in global sea level (Fig. 21) and accelerated subsidence in the Salton Trough basin, which requires a large and sustained increase in river sediment output starting $\sim 4.8-4.5 \mathrm{Ma}$ (Dorsey et al., 2011). Sediment discharge from the Colorado River has averaged $\sim 156 \pm 60 \mathrm{Mt} . / \mathrm{yr}$ since $5.3 \mathrm{Ma}$, or $172 \pm 66$ Mt./yr assuming all sediment flux is post-4.8 Ma (Dorsey and Lazear, 2013). This rate is indistinguishable from pre-dam modern sediment discharge in Yuma during the early 1900's $(172 \pm 64 \mathrm{Mt} . / \mathrm{yr})$, and is much greater than the early Pliocene river sediment flux estimated above (4-20 Mt./yr).

We therefore conclude that river sediment output to the ocean was initially weak and slow, it was then significantly reduced for a short time, and it later increased dramatically to modern pre-dam levels when delta progradation resumed at $\sim 4.8-4.5 \mathrm{Ma}$. The reasons for fluctuations in sediment discharge remain uncertain, but likely included a combination of erosion on the Colorado Plateau, possible tributary capture events, subsidence and sediment trapping in structurally controlled sub-basins along the lower river corridor, and changes in global sea level through time. Massive progradation of the fluvial-deltaic system back down the river valley into the Salton Trough at $\sim 4.8-4.5 \mathrm{Ma}$ coincides with a huge increase of river sediment discharge to modern pre-dam values. The timing of these events suggests that sediment flux from the upper river catchment (Colorado Plateau) increased by several orders of magnitude at that time, possibly due to capture of the Green River (Darling, 2016), and overwhelmed the storage capacity of sub-basins along the lower Colorado River transfer subsystem.

\section{Conclusions}

This study provides new insights into depositional processes, environments, and age of the Miocene-Pliocene southern Bouse Formation and similar-aged deposits in the western Salton Trough. Our data provide evidence for a punctuated start-stop-start history of sediment discharge during initiation and early evolution of the Colorado River. The unsteady birth of the river was modulated by a complex interplay among erosion, sediment flux, basin subsidence, and global sea-level change, many details of which remain poorly understood. The reconstructed sequence of events prior to and during river integration is summarized below.

1. In latest Miocene time ( 6.3-5.4 Ma), marine waters flooded the lower Colorado River valley, Salton Trough, and northern Gulf of California in a zone of transtensional basins that formed along and adjacent to the evolving Pacific - North America plate boundary. 
Deposition took place during a fall in global sea level, implicating tectonic subsidence as the primary control on marine transgression in the lower Colorado River valley.

2. The transition from southern Bouse subtidal carbonate to green claystone at $\sim 5.4-5.3 \mathrm{Ma}$ records sudden arrival of clay carried by first-arriving waters of the Colorado River. Mixing of marine and freshwater faunas in this interval resulted from a new influx of river water and sediment, analogous to mixing of microfaunas that took place at the end of the Younger Dryas period when catastrophic floods from glacial Lake Agassiz rapidly flushed large volumes of fresh water into the St. Lawrence estuary.

3. Starting $\sim 5.4-5.3 \mathrm{Ma}$, the Colorado River delta prograded rapidly down the lower river valley and exported river sand into the offshore Gulf of California, depositing sand-rich turbidites in the Wind Caves submarine paleocanyon (Salton Trough). Delta progradation and formation of a regional unconformity at the base of the Bouse upper bioclastic member took place during a large rapid fall in global sea level, suggesting a direct eustatic control on earliest integration of the Colorado River to the ocean.

4. Delta progradation was followed by shut-down of river sand output from $\sim 5.1$ to $4.8 \mathrm{Ma}$, deposition of widespread marine clay in the Salton Trough, regional backstepping of the delta, and re-flooding of the southernmost river valley by shallow marine waters that formed the upper bioclastic member of the southern Bouse Formation. Delta retreat may have been caused by temporary trapping of sand due to subsidence in basins along the river corridor; other controls are also possible and cannot be ruled out at this time. 5. Resumption of sediment discharge drove massive progradation of fluvial-deltaic deposits back down the river into the northern Gulf of California starting $\sim 4.8-4.5 \mathrm{Ma}$, possibly in response to a large increase in sediment output from the upper river catchment at that time.

Our results highlight the importance of integrating stratigraphic data with process sedimentology, paleontology and geochronology for reconstructing paleo-river dynamics in tectonically active regions. It is difficult to distinguish the influence of global sea-level change from vertical crustal motions on changes in accommodation space, because the vertical scale and rates of these processes are similar and their relative importance are subject to changes in space and time (e.g. Gawthorpe et al., 1994). Comparison of the stratigraphic record to an established chronology of global eustatic sea-level change thus provides a powerful tool for interpreting controls on changes in paleogeography, grain-size partitioning, and sediment discharge during the birth and early evolution of the Colorado River system.

\section{Acknowledgments}

Research for this study was supported by grants from the National Science Foundation (grant EAR-1546006), Society for Sedimentary Geology, and Geological Society of America. We appreciate the invitation from Timothy Horscroft to share these data and results with an international audience. Brian Romans, Sue Beard, and an anonymous reviewer provided constructive reviews of an earlier draft of this paper. We thank Sue Beard, Scott Bennett, Jordon Bright, Andy Cohen, Laurie Crossey, Kyle House, Keith Howard, Karl Karlstrom, Phil Pearthree, and Jon Spencer for insightful discussions and diverse perspectives on the Bouse Formation and origins of the Colorado River. Adriana Miranda- Martínez is thanked for providing useful new microfossil identifications and interpretations. Austin Hendy and Greg Retallack are thanked for help with fossil identifications and discussions of Bouse paleogeography. Ken Miller kindly provided a Gaussian filter algorithm for smoothing the sea-level curve in Fig. 21. 


\section{REFERENCES CITED}

Abbott, P.L., Kerr, D.R., Borron, S.E., Washburn, J.L., and Rightmer, D.A., 2002. Neogene sturzstrom deposits, Split Mountain area, Anza-Borrego Desert State Park, California. In: Evans, S.G., and DeGraff, J.V. (Eds.), Catastrophic Landslides: Effects, Occurrence, and Mechanisms: Geological Society America, Reviews in Engineering Geology 15, 379-400.

Ahel, M., Barlow, R.G., and Mantoura, R.F.C., 1996. Effect of salinity gradients on the distribution of phytoplankton pigments in a stratified estuary. Marine Ecology Progress Series, v. 143, p. 289-295.

Ahmed, S., Bhattacharya, J.P., Garza, D.E. and Li, Y., 2014. Facies architecture and stratigraphic evolution of a river-dominated delta front, Turonian Ferron Sandstone, Utah, USA. Journal Sedimentary Research 84, 97-121.

Ainsworth, R.B., Hasiotis, S.T., Amos, K.J., Krapf, C.B.E., Payenberg, T.H.D., Sandstrom, M.L., Vakarelov, B.K., and Lang, S.C., 2012. Tidal signatures in an intracratonic playa lake. Geology 40, 607610.

Allen, P.A., 2008. From landscapes into geological history. Nature 451(7176), 274-276.

Almogi-Labin, A., Perelis-Grossovicz, L., and Raab, M., 1992. Living Ammonia from a 642 hypersaline inland Pool, Dead Sea Area, Israel. Journal Foraminiferal Research 22, 257-266.

Arnal, R.E., 1955. Some occurrences of abnormal foraminifera. Compass of Sigma Gamma Epsilon, 1915-84. 32(3), 185-194.

Arnal, R.E., 1961. Limnology, sedimentation, and microorganisms of the Salton Sea, California. Geological Society America Bulletin 72, 427-478.

Axen, G.J., and Fletcher, J.M., 1998. Late Miocene-Pleistocene extensional faulting, northern Gulf of California, Mexico and Salton Trough, California. International Geology Review 40, 217-244.

Bandy, O.L., 1961. Distribution of foraminifera, radiolaria and diatoms in sediments of the Gulf of California. Micropaleontology 7, 1-26.

Bartley, J.M. and Glazner, A.F., 1991. En echelon Miocene rifting in the southwestern United States and model for vertical-axis rotation in continental extension. Geology 19, 1165-1168.

Beard, L.S., Haxel, G.B., Dorsey, R.J., McDougall, K.A., and Jacobson, C.E., 2016. Late Neogene deformation of the Chocolate Mountains Anticlinorium: Implications for deposition of the Bouse Formation and early evolution of the Lower Colorado River. In: Reynolds, R.E. (Ed.), 2016 Desert Symposium Field Guide and Proceedings, California State University Desert Studies Center, Zzyzx, CA, p. 176-184.

Bennett, S.E.K., Oskin, M.E., and Iriondo, A., 2013. Transtensional ri_ing in the proto-Gulf of California, near Bahía Kino, Sonora, México: Geological Society America Bulletin 125, 1752-1782.

Bennett, S.E.K., Oskin, M.E., Dorsey, R.J., Iriondo, A., and Kunk, M.J., 2015. Stratigraphy and structural development of the southwest Isla Tiburón marine basin: Implications for latest Miocene tectonic opening and flooding of the northern Gulf of California. Geosphere 11, no. 4, doi:10.1130/GES01153.1.

Bennett, S.E., Oskin, M.E., Iriondo, A. and Kunk, M.J., 2016a. Slip history of the La Cruz fault: Development of a late Miocene transform in response to increased rift obliquity in the northern Gulf of California. Tectonophysics 693, 409-435.

Bennett, S.E.K., Darin, M.H., Dorsey, R.J., Skinner, L.A., Umhoefer, P.J., and Oskin, M.E., 2016b. Animated tectonic reconstruction of the Lower Colorado River region: implications for Late Miocene to Present deformation. In: Reynolds, R.E. (Ed.), 2016 Desert Symposium Field Guide and Proceedings, 
California State University Desert Studies Center, Zzyzx, CA, p. 73-86.

Blow, W.H., 1979. The Cainozoic Globigerinidae. A Study of the Morphology, Taxonomy, Evolutionary Relationship and the Stratigraphical Distribution of Some Globigerinidae (Mainly Globigerinacea). vol. 3 E.J. Brill Ed., Leiden, Netherlands, 1413 p.

Booler, J., \& Tucker, M. E., 2002. Distribution and geometry of facies and early diagenesis: the key to accommodation space variation and sequence stratigraphy: Upper Cretaceous Congost Carbonate platform, Spanish Pyrenees. Sedimentary Geology 146(3), 225-247.

Bradshaw, J.S., 1957. Laboratory Studies on the Rate of Growth of the Foraminifer, "Streblus beccarii (Linné) var. tepida (Cushman)". Journal Paleontology, 31, 1138-1147.

Brand, U., and Veizer, J., 1980. Chemical diagenesis of a multicomponent carbonate system: 1. Trace elements: Journal Sedimentary Research 50, 1219-1236.

Bridge, J.S., and Diemer, J.A., 1983. Quantitative interpretation of an evolving ancient river system. Sedimentology 30, 599-623.

Bright, J., Cohen, A.S., Dettman, D.L., Pearthree, P.A., Dorsey, R.J., and Homan, M.B., 2016. Did a catastrophic lake spillover integrate the late Miocene early Pliocene Colorado River and the Gulf of California?: Microfaunal and stable isotope evidence from Blythe Basin, California-Arizona, USA. Palaios 31, 81-91.

Buising, A.V., 1988. Depositional and Tectonic Evolution of the Northern Proto-Gulf of California and Lower Colorado River, as Documented in the Mio-Pliocene Bouse Formation and Bracketing Units, Southeastern California and Western Arizona [Ph.D. thesis]: Santa Barbara, University of California, 196 p.

Buising, A.V., 1990. The Bouse Formation and bracketing units, southeastern California and western Arizona: Implications for the evolution of the proto-Gulf of California and the lower Colorado River. Journal Geophysical Research 95, 20,111-20,132.

Burone , L., Ortega, L., Franco-Fraguas, P., Mahiques, M., Garcla-Rodriguez, F., Venturini, N., Marin, Y., Brugnoli, E., Nagai, R., Muniz, P., Bıcego, M., Figueira, R., and Salaroli, A., 2013. A multiproxy study between the Rı dela Plata and the adjacent Southwestern Atlantic inner shelf to assess the sediment footprint of river vs. marine influence. Continental Shelf Research 55, 141-154.

Bykerk-Kauffman, A., 2017. Neogene sedimentation, volcanism, and faulting in the eastern Coyote Mountains, Salton Trough, southern California. In: Kraatz, B., Lackey, J.S., and Fryxell, J.E. (Eds.) Field Excursions in Southern California: Field Guides to the 2016 GSA Cordilleran Section Meeting, Geological Society of America Field Guide 45, 49-79.

Cann, J.H., and de Dekker, P., 1981. Fossil Quaternary and living foraminifera from athalassic (nonmarine) saline lakes, southern Australia. Journal Paleontology 55, 660-670.

Castelltort, S. and Van Den Driessche, J., 2003. How plausible are high-frequency sediment supplydriven cycles in the stratigraphic record?. Sedimentary Geology 157, 3-13.

Cattaneo, A., and Steel, R.J., 2003. Transgressive deposits: a review of their variability. Earth-Science Reviews 62, 187-228.

Catuneanu, O., Abreu, V., Bhattacharya, J.P., and 25 others, 2009. Toward the standardization of sequence stratigraphy. Earth Science Reviews 92, 1-33.

Catuneanu, O., Galloway, W.E., Kendall, C.G.S.C., Miall, A.D., Posamentier, H.W., Strasser, A. and Tucker, M.E., 2011. Sequence stratigraphy: methodology and nomenclature. Newsletters on stratigraphy 44(3), 173-245. 
Chaisson, W.P., and Leckie, R.M., 1993. High-resolution Neogene planktonic foraminifer biostratigraphy of Site 806, Ontong Java Plateau (western equatorial Pacific). In: Berger, W.H., Kroenke, L.W., and Mayer, L.A. (Eds.), Proceeding of the Ocean Drilling Program, Scientific Results 130, 137-178.

Chapin, C.E. and Cather, S.M., 1994. Tectonic setting of the axial basins of the northern and central Rio Grande rift. Geological Society of America Special Paper 291, 5-26.

Clark, M.K., Schoenbohm, L.M., Royden, L.H., Whipple, K.X., Burchfiel, B.C., Zhang, X., Tang, W., Wang, E. and Chen, L., 2004. Surface uplift, tectonics, and erosion of eastern Tibet from large-scale drainage patterns. Tectonics 23, TC1006, doi:10.1029/2002TC001402.

Clift, P.D. and Blusztajn, J., 2005. Reorganization of the western Himalayan river system after five million years ago. Nature 438, 1001-1003.

Cloos, M.E., 2014. Detrital zircon U-Pb and (U-Th)/He geo-thermochronometry and submarine turbidite fan development in the Mio-Pliocene Gulf of California, Fish Creek-Vallecito Basin, southern California. Unpubl. M.S. thesis, University of Texas, Austin, Texas, 216 p.

Connell, S.D., Hawley, J.W. and Love, D.W., 2005. Late Cenozoic drainage development in the southeastern Basin and Range of New Mexico, southeasternmost Arizona, and western Texas. New Mexico's ice ages: New Mexico Museum of Natural History and Science, Bulletin 28, 125-150.

Cope, C.C. and Herrmann, A.D., 2004. Bioindicators of environmental change in the Chesapeake Bay. Geological Society America Abstracts with Programs 36(5), 235.

Cronin, T.M., Rayburn, J.A., Guilbault, J.-P., Thunell, R., Franzi, D.A., 2012. Stable isotope evidence for glacial lake drainage through the St. Lawrence Estuary, eastern Canada, 13.1-12.9 ka. Quaternary International 260, 55-65.

Crossey, L.C., Karlstrom K.E., Crow R.S., Ferguson, C., and Dorsey, R.J., 2017. Towards a depositional model for travertines of the Bouse Formation: examples from the southern Blythe Basin. In: Reynolds, R.E. (Ed.), 2017 Desert Symposium Field Guide and Proceedings, California State University Desert Studies Center, Zzyzx, CA, p. 174-179.

Crossey, L.C., Karlstrom, K.E., Dorsey, R., Pearce, J., Wan, E., Beard, L.S., Asmerom, Y., Polyak, V., Crow, R.S., Cohen, A. and Bright, J., 2015. Importance of groundwater in propagating downward integration of the 6-5 Ma Colorado River system: Geochemistry of springs, travertines, and lacustrine carbonates of the Grand Canyon region over the past $12 \mathrm{Ma}$. Geosphere 11(3), 660-682.

Crow, R.S., House, P.K., Howard, K.A., Karlstrom, K.E., Heizler, M.T., Polyak, V.J., Asmerom, Y., Pearthree, P.A., O'Connell, B., Crossey, L,J., Champion, D., Beard, L.S., Dorsey, R.J., McDougall, K., 2016. Deciphering lower Colorado River integration processes through geochronologic studies of the Bouse Formation; preliminary results and future directions. Geological Society America Abstracts with Programs 48(7), 301-5.

Cukrov, N., Barišic, D., and Juracic, M., 2007. Calculated sedimentation rate in the Krka River estuary using vertical distribution of ${ }^{137} \mathrm{Cs}$. Rapp. Comm. int. Mer Medit., p. 38.

Culver, S.J., and Buzas, M.A., 1986. Distribution of recent benthic foraminifera off the North American Pacific coast from California to Baja. Smithsonian Contributions to the Marine Sciences 28, 634 pp.

Cummings, D.I., Dumas, S. and Dalrymple, R.W., 2009. Fine-grained versus coarse-grained wave ripples generated experimentally under large-scale oscillatory flow. Journal Sedimentary Research 79, 83-93.

Dalrymple, R.W., and Choi, K., 2007. Morphologic and facies trends through the fluvial-marine transition in tide-dominated depositional systems: A schematic framework for environmental and sequence stratigraphic interpretation. Earth-Science Reviews 81, 135-174. 
Darling, A.L., 2016. The roles of erosion rate and rock strength in the evolution of canyons along the Colorado River. Unpubl. Ph.D. thesis, Arizona State University, Tempe, Arizona, 214 pp.

Davis, G.A. and Lister, G.S., 1988. Detachment faulting in continental extension; perspectives from the southwestern US Cordillera. Geological Society America Special Paper 218, 133-160.

De Boer, P.L., Oost, A.P., and Visser, M.J., 1989. The diurnal inequality of the tide as a parameter for recognizing tidal influences. Journal Sedimentary Research 59, 912-921.

DeCelles, P.G., 1987. Variable preservation of middle Tertiary, coarse-grained, nearshore to outer-shelf storm deposits in southern California. Journal Sedimentary Petrology 57, 250-264.

Delaca, T.E. and Lipps, J.H., 1972. The mechanism and adaptive significance of attachment and substrate pitting in the foraminiferan Rosalina globularis d'Orbigny. Journal Foraminiferal Research 2, 6872.

Dibblee, T.W., Jr., 1984. Stratigraphy and tectonics of the San Felipe Hills, Borrego Badlands, Superstition Hills, and vicinity, In: Rigsby, C.A. (Ed.), The Imperial Basin - Tectonics, Sedimentation, and Thermal Aspects: Los Angeles, California, Pacific Section, Society of Economic Paleontologists and Mineralogists, 31-44.

Dibblee, T.W., 1997. Geology of the southeastern San Andreas fault zone in the Coachella Valley area, southern California. In: Baldwin, et al. (Eds.), Southern San Andreas Fault -Whitewater to Bombay Beach, Salton Trough, California. South Coast Geological Society (Field Trip Guidebook No. 25, p. 35-56).

Dickinson, W.R., and Gehrels, G.E., 2009. Use of U-Pb ages of detrital zircons to infer maximum depositional ages of strata: a test against a Colorado Plateau Mesozoic database. Earth Planetary Science Letters 288, 115- 125.

Dobson, M. and Haynes, J., 1973. Association of foraminifera with hydroids on the deep shelf. Micropaleontology 19, 78-90.

Dokka, R.K. and Travis, C.J., 1990. Role of the eastern California shear zone in accommodating PacificNorth American plate motion. Geophysical Research Letters 17, 1323-1326.

Dorsey, R.J., and Becker, U., 1995. Evolution of a large Miocene growth structure in the upper plate of the Whipple detachment fault, northeastern Whipple Mountains, California. Basin Research 7, 151-163.

Dorsey, R.J., and Lazear, G., 2013. A Post 6-Ma Sediment Budget for the Colorado River. Geosphere 9, 781-791.

Dorsey, R.J., Axen, G.J., Peryam, T.C., and Kairouz, M.E., 2012. Initiation of the southern Elsinore fault at 1.2 Ma: Evidence from the Fish Creek - Vallecito Basin, southern California. Tectonics 31, TC2006, doi:10.1029/2011TC003009.

Dorsey, R.J., 2010. Sedimentation and crustal recycling along an active oblique-rift margin: Salton Trough and northern Gulf of California. Geology 38, 443-446.

Dorsey, R.J., Fluette, A.. McDougall, K., Housen, B.A., Janecke, S.U., Axen, G.J., and Shirvell, C.R., 2007. Chronology of Miocene-Pliocene deposits at Split Mountain Gorge, southern California: A record of regional tectonics and Colorado River evolution. Geology 35, 57-60.

Dorsey, R.J., Housen, B.A., Janecke, S.U., Fanning, C.M., and Spears, A.L.F., 2011. Stratigraphic record of basin development within the San Andreas fault system: Late Cenozoic Fish Creek-Vallecito basin, southern California. Geological Society America Bulletin 123, 771-793. 
Dorsey, R.J., O'Connell, B., Homan, M., and Howard, K.A., 2016. Upper limestone of the southern Bouse Formation: Evidence for unsteady origins of the Colorado River. In: Reynolds, R.E. (Ed.) 2016 Desert Symposium Proceedings, California State University Desert Studies Center, Zzyzx, CA, p. 145-153.

Dorsey, R.J., O'Connell, B., Homan, M., and Bennett, S.E.K., 2017. Influence of the Eastern California Shear Zone on deposition of the Mio-Pliocene Bouse Formation: Insights from the Cibola area, Arizona. In: Reynolds, R.E. (Ed.), 2017. Desert Symposium Field Guide and Proceedings, California State University Desert Studies Center, Zzyzx, CA, 150-157.

Eichler, P.P.B., Rodrigues, A.R., Eichler, B.B., Braga, E.S., and Campos, E.J.D., 2012. Tracing latitudinal gradient, river discharge and water masses along the Subtropical South American Coast using benthic Foraminifera assemblages. Brazilian Journal Biology 72(3) (suppl.), 723-759.

Ethridge, F. G., and Wescott, V.A., 1984. Tectonic setting, recognition and hydrocarbon reservoir potential of fan-delta deposits. In: Koster, E. H., and Steel, R. J. (Eds.), Sedimentology of gravels and conglomerates, Canadian Society of Petroleum Geologists Memoir 10, pp. 217-235.

Figueiredo, J., Hoorn, C., van der Ven, P., and Soares, E., 2009. Late Miocene onset of the Amazon River and the Amazon deep-sea fan: Evidence from the Foz do Amazonas Basin. Geology 37, 619-622.

Ford, T.D., and Pedley, H.M., 1996. A review of tufa and travertine deposits of the world. Earth-Science Reviews, 41, 117-175.

Foster, M.S., Riosmena-Rodriguez, R., Steller, D.L., and Woelkerling, W.J., 1997. Living rhodolith beds in the Gulf of California and their implications for paleoenvironmental interpretation. In: Johnson, M.E. and Ledesma-Vasquez, J. (Eds.), Pliocene Carbonates and Related Facies Flanking the Gulf of California, Baja California Sur, Mexico. Geological Society America Special Paper 318, pp. 127-139.

Fuis, G.S., Mooney, W.D., Healy, J.H., McMechan, G.A. and Lutter, W.J., 1984. A seismic refraction survey of the Imperial Valley region, California. Journal Geophysical Research: Solid Earth 89, 11651189.

Gaillardet, J., Dupré, B., Louvat, P., and Allegrè, C.J., 1999. Global silicate weathering and CO consumption rates deduced from the chemistry of large rivers. Chemical Geology 159 3-30.

Galloway, W.E., Whiteaker, T.L. and Ganey-Curry, P., 2011. History of Cenozoic North American drainage basin evolution, sediment yield, and accumulation in the Gulf of Mexico basin. Geosphere 7(4), 938-973.

Gawthorpe, R.L., Fraser, A.J., and Collier, R.E.L., 1994. Sequence stratigraphy in active extensional basins: implications for the interpretation of ancient basin-fills. Marine and Petroleum Geology 11, 642-658.

Gootee, B.F., Pearthree, P.A., House, P.K., Youberg, A., O'Connell, B., and Bright, J., 2016. A sequencestratigraphic interpretation of the upper bioclastic unit capping the Bouse Formation in the Cibola Area, Arizona and California. In: Reynolds, R.E. (Ed.) 2016 Desert Symposium Proceedings, California State University Desert Studies Center, Zzyzx, CA, p. 154-159.

Gradstein, F.M., Ogg, J.G., Schmitz, M.D., Ogg, G.M., 2012. A Geologic Time Scale 2012. Elsevier, Boston, $1176 \mathrm{pp}$.

Halfar, J., Ingle, J.C., and Godinez-Orta, L., 2004. Modern non-tropical mixed carbonate-siliciclastic sediments and environments of the southwestern Gulf of California, Mexico. Sedimentary Geology 165, 93-115.

Halfar, J., Strasser, M., Riegl, B., and Godinez-Orta, L., 2006. Oceanography, sedimentology and acoustic mapping of a bryomol carbonate factory in the northern Gulf of California, Mexico. In: Pedley, H.M., and Carannante, G. (Eds.), Cool-Water Carbonates: Depositional Systems and

Palaeoenvironmental Controls, Geological Society London Special Publication 255, pp. 197-215. 
Hanna, G.D., 1926. Paleontology of Coyote Mountain, Imperial County, California: Proceeding of the California Academy of Sciences, fourth series, 14, 427-503.

Harvey, 2014. Zircon age and oxygen isotopic correlations between Bouse Formation tephra and the Lawlor Tuff. Geosphere 10, 221-232.

Hemleben, C., Spindler, M., and Anderson, O.R., 1989. Modern Planktonic Foraminifera. Springer-Verlag, New York, 363 p.

Hirschaut, D.W. and Dingler, J.R., 1982. A field study of large-scale oscillation ripples in a very coarsegrained, high-energy marine environment. US Geological Survey Open File Report 82-733, 33 p.

Holbrook, J., 2001. Origin, genetic interrelationships, and stratigraphy over the continuum of fluvial channel-form bounding surfaces: an illustration from middle Cretaceous strata, southeastern Colorado. Sedimentary Geology 144, 179-222.

Homan, M.B., 2014. Sedimentology and stratigraphy of the Miocene-Pliocene Bouse Formation near Cibola, Arizona, and Milpitas Wash, California: Implications for the early evolution of the Colorado River. Unpub. M.S. thesis, University of Oregon, Eugene, Oregon, $116 \mathrm{p}$.

Horstwood, M.S.A., Foster, G.L., Parrish, R.R., Noble, S.R., and Nowell, G.M., 2003. Common-Pb corrected in situ U-Pb accessory mineral geochronology by LA-MC-ICPMS. Journal of Analytical Atomic Spectrometry 18, 837-846.

Horton, B.P., 1999. The distribution of contemporary intertidal foraminifera at Cowpen Marsh, Tees Estuary, UK: Implications for studies of Holocene sea level changes. Palaeogeography,

Palaeoclimatology, Palaeoecology 149, 127-149.

House, P.K., Pearthree, P.A., and Perkins, M.E., 2008. Stratigraphic evidence for the role of lake spillover in the inception of the lower Colorado River in southern Nevada and western Arizona, In: Reheis, M.C., Hershler, R., and Miller, D.M. (Eds.), Late Cenozoic Drainage History of the Southwestern Great Basin and Lower Colorado River Region: Geologic and Biotic Perspectives. Geological Society America Special Paper 439, 335-353.

Howard, K.A., House, P.K., Dorsey, R.J., and Pearthree, P.A., 2015. River-evolution and tectonic implications of a major Pliocene aggradation on the lower Colorado River, the Bullhead Alluvium. Geosphere 11, 1-30.

Howard, K.A., Malmon, D.V., Hillhouse, J.W., Dorsey, R.J., Crow, R.S., and House, P.K., 2016. Magnetostratigraphic constraints on the Bouse Formation in the Blythe Basin- existing evidence. In: Reynolds, R.E. (Ed.), 2016 Desert Symposium Field Guide and Proceedings, California State University Desert Studies Center, Zzyzx, CA, p. 97-100.

Ingle, J.C., 1974. Paleobathymetric history of Neogene marine sediments, northern Gulf of California in Geology of Peninsular California. In: Gastil, G., and Lillengraven, J. (Eds.), The Geology of Peninsular California. Guide Book Pacific Section, American Association of Petroleum Geologists, pp. 121-138.

Ingle, J.C., Jr., 1980. Cenozoic paleobathymetry and depositional history of selected sequences within the southern California continental borderland in Ingle, J.C., Jr., Kennett, J.P., Kolpack, T., and Vincent, E., eds., Studies in Marine Micropaleontology and Paleoecology: A Memorial Volume to Orville L. Bandy. Cushman Foundation for Foraminiferal Research Special Publication 19, 163-195.

Ingram, B.L., Ingle, J.C., and Conrad, M.E., 1996. A 2000 yr record of Sacramento-San Joaquin river inflow to San Francisco Bay estuary, California. Geology 24, 331-334.

Ingram, B.L., De Deckker, P., Chivas, A.R., Conrad, M.E. and Byrne, A.R., 1998. Stable isotopes, Sr/Ca, and $\mathrm{Mg} / \mathrm{Ca}$ in biogenic carbonates from Petaluma Marsh, northern California, USA. Geochimica et Cosmochimica Acta 62(19), 3229-3237. 
Issa, B.M., 2010. Depositional environments and biofacies of selected sediments, north Basrah. Journal Basrah Res. (Sciences) 36, 1-14.

James, N.P., 1997. The cool-water carbonate depositional realm, In: James, N.P., and Clarke, J.A.D. (Eds.), Cool-water carbonates: SEPM (Society for Sedimentary Geology) Special Publication 56, 1-22.

Janecke, S.U., Dorsey, R.J., Forand, D., Steely, A.N., Kirby, S.M., Lutz, A.T., Housen, B.A., Belgarde, B., Langenheim, V.E. and Rittenour, T.M., 2011. High geologic slip rates since early Pleistocene initiation of the San Jacinto and San Felipe fault zones in the San Andreas fault system: Southern California, USA. Geological Society of America Special Paper 475, 1-48.

Javaux, E.J., and Scott, D.B., 2003. Illustration of modern benthic foraminifera from Bermuda and remarks on distribution in other subtropical/tropical areas. Paleontologica Electronica 6, 29 pp.

Jefferson, G.T., and Lindsay, L.E. (Eds.), 2006. Fossil Treasures of Anza-Borrego Desert: San Diego, California, Sunbelt Publications, $394 \mathrm{p}$.

Johnson, N.M., Officer, C.B., Opdyke, N.D., Woodard, G.D., Zeitler, P.K., and Lindsay, E.H., 1983. Rates of late Cenozoic tectonism in the Vallecito-Fish Creek basin, western Imperial Valley, California. Geology 11 664-667.

Jones, B. and Renaut, R.W., 2010. Calcareous spring deposits in continental settings. Developments in Sedimentology 61, 177-224.

Kerr, D.R., and Abbott, P.L., 1996. Miocene subaerial sturzstrom deposits, Split Mountain, Anza-Borrego Desert State Park. In: Abbott, P.L., and Seymour, D.C. (Eds.), Sturzstroms and Detachment Faults, AnzaBorrego Desert State Park, California: Santa Ana, California, South Coast Geological Society, pp. 149163.

Kimbrough, D.L., Grove, M., Gehrels, G.E., Dorsey, R.J., Howard, K.A., Lovera, O., Aslan, A., House, P.K., and Pearthree, P.A., 2015. Detrital zircon U-Pb provenance record of the Colorado River: Implications for late Cenozoic drainage evolution of the American Southwest. Geosphere 11(6), 30 pages.

Langer, M.R., 1993. Epiphytic foraminifera. Marine Micropaleontology 20, 235-265.

Lankford, R.R. and Phleger, F.B., 1973. Foraminifera from the nearshore turbulent zone, western North America. Journal Foraminiferal Research 3, 101-132.

Leckie, D., 1988. Wave-formed, coarse-grained ripples and their relationship to hummocky crossstratification. Journal of Sedimentary Research 58, 607-622.

Leckie, D.A., and Walker, R.G., 1982. Storm-and tide-dominated shorelines in Cretaceous MoosebarLower Gates interval--outcrop equivalents of Deep Basin gas trap in western Canada. American Association Petroleum Geologists Bulletin 66, 138-157.

Leithold, E.L., and Bourgeois, J., 1984. Characteristics of coarse-grained sequences deposited in nearshore, wave-dominated environments-examples from the Miocene of south-west Oregon. Sedimentology 31, 749-775.

Lisiecki, L.E. and Raymo, M.E., 2005. A Pliocene-Pleistocene stack of 57 globally distributed benthic $\delta 180$ records. Paleoceanography 20, PA1003, doi:10.1029/2004PA001071.

Martinsen, O.J., Ryseth, A.L.F., Helland-Hansen, W., Flesche, H., Torkildsen, G., \& Idil, S., 1999. Stratigraphic base level and fluvial architecture: Ericson Sandstone (Campanian), Rock Springs Uplift, SW Wyoming, USA. Sedimentology 46, 235-263. 
Mason, C.C., Spotila, J.A., Axen, G.J., Dorsey, R.J., Luther, A., and Stockli, D., submitted. Two-phase exhumation of the Santa Rosa Mountains: low- and high-angle normal faulting during initiation and evolution of the southern San Andreas fault system. Submitted to Tectonics.

Matmon, A., Stock, G.M., Granger, D.E., and Howard, K.A., 2012. Dating of Pliocene Colorado River sediments; implications for cosmogenic burial dating and the evolution of the lower Colorado River. Geological Society America Bulletin 124, 626-640.

McDougall, K., 2008. Late Neogene marine incursions and the ancestral Gulf of California. In, Reheis, M., Herschler, R., and Miller, D. (Eds.), Late Cenozoic Drainage History of the Southwestern Great Basin and Lower Colorado River Region: Geologic and Biotic Perspectives. Geological Society of America Special Paper 439, pp. 355-373.

McDougall, K.A., Poore, R.Z., and Matti, J.C., 1999. Age and paleoenvironment of the Imperial Formation near San Gorgonio Pass, southern California: Journal of Foraminiferal Research 29, 4-25.

McDougall, K., and Miranda-Martínez, A.Y., 2014. Evidence for a marine incursion along the lower Colorado River corridor. Geosphere 10, 842-869.

Meng, X., Ge, M., Tucker, M. E., 1997. Sequence stratigraphy, sea-level changes and depositional systems in the Cambro-Ordovician of the North China carbonate platform. Sedimentary Geology 114, 189-223.

Metzger, D.G., 1968. The Bouse Formation (Pliocene) of the Parker-Blythe-Cibola Area, Arizona and California. U.S. Geological Survey Professional Paper 600-D, D126-D136.

Metzger, D.G., Loeltz, O.J., and Irelan, B., 1973. Geohydrology of the Parker-Blythe-Cibola area, Arizona and California. U.S. Geological Survey Professional Paper 486-G, 130 p.

Meybeck, M., 1987. Global chemical weathering of surficial rocks estimated from river dissolved loads. American Journal Science 287, 401-428.

Meyers, W.J., 1977. Chertification in the Mississippian Lake Valley Formation, Sacramento Mountains, New Mexico. Sedimentology 24, 75-105.

Miall, A.D., 1996. The Geology of Fluvial Deposits. Springer-Verlag. 582 pp.

Michael, N.A., Whittaker, A.C. and Allen, P.A., 2013. The functioning of sediment routing systems using a mass balance approach: example from the Eocene of the southern Pyrenees. Journal Geology 121, 581606.

Miller, K.G., Kominz, M.A., Browning, J.V., Wright, J.D., Mountain, G.S., Katz, M.E., Sugarman, P.J., Cramer, B.S., Christie-Blick, N. and Pekar, S.F., 2005. The Phanerozoic record of global sea-level change. Science 310, 1293-1298.

Miller, K.G., G.S. Mountain, J.D. Wright, and J.V. Browning. 2011. A 180-million-year record of sea level and ice volume variations from continental margin and deep-sea isotopic records. Oceanography 24(2), 40-53.

Miller, D.M., Reynolds, R.E., Bright, J.E. and Starratt, S.W., 2014. Bouse Formation in the Bristol basin near Amboy, California, USA. Geosphere 10(3), 462-475.

Milliman, J. D., and Meade, R. H., 1983. World-wide delivery of river sediment to the oceans. Journal Geology 91, 1-21.

Milliman, J.D., and Farnsworth, K.L., 2011. River discharge to the coastal ocean: A global synthesis. Oceanography, 24(4), 143-144. 
Miranda-Martínez, A.Y., Carreno, A.L., and McDougall, K., 2017. The Neogene genus Streptochilus (Brönnimann and Resig, 1971) from the Gulf of California. Marine Micropaleontology 132, 35-52.

Murray, A.B. and Thieler, E.R., 2004. A new hypothesis and exploratory model for the formation of largescale inner-shelf sediment sorting and "rippled scour depressions". Continental Shelf Research 24, 295315.

Nemec, W., 1990. Deltas - remarks on terminology and classification. In: Colella, A., and Prior, D.B. (Eds.), Coarse-grained Deltas, Special Publication International Association Sedimentologists 10, 3-12.

Nielson, J.E. and Beratan, K.K., 1990. Tertiary basin development and tectonic implications, Whipple detachment system, Colorado River extensional corridor, California and Arizona. Journal of Geophysical Research: Solid Earth 95, 599-614.

Nikolaev, S. D., Oskina, N. S., Bylum, N. S. and Bubenshchikova, N. V., 1998. Neogene-Quaternary variations in the 'Pole-Equator' temperature gradient of the surface oceanic waters in the North Atlantic and North Pacific. Global and Planetary Change 18, 85-111.

Noble, L.F., 1931. Nitrate deposits in southeastern California, with notes on deposits in southwestern Arizona and southwestern New Mexico. U.S. Geological Survey Bulletin 820, 108 pp.

O'Connell, B., 2016. Sedimentology and depositional history of the Miocene-Pliocene southern Bouse Formation, Arizona and California. Unpub. M.S. thesis, University of Oregon, Eugene, Oregon, 148 p.

O'Connell, B., Dorsey, R.J., and Humphreys, E.D., 2017. Tidal rhythmites in the southern Bouse Formation as evidence for post-Miocene uplift of the lower Colorado River corridor. Geology 45, 99-102.

Ohtsuka, S., Suzaki, T., Horiguchi, T., Suzuki, N. and Fabrice, N., editors, 2015. Marine Protists: Diversity and Dynamics. Springer, Tokyo, 648 pp.

Olariu, C., \& Bhattacharya, J. P., 2006. Terminal distributary channels and delta front architecture of riverdominated delta systems. Journal of Sedimentary Research 76, 212-233.

Olmsted, F.H., Loeltz, O.J., and Irelan, B., 1973. Geohydrology of the Yuma area, Arizona and California: Water resources of lower Colorado River-Salton Sea area. U.S. Geological Survey Professional Paper 486-H, $227 \mathrm{p}$.

Oskin, M., and Stock, J., 2003. Marine incursion synchronous with plate boundary localization in the Gulf of California: Geology 31, 23-26.

Paola, C., 2000. Quantitative models of sedimentary basin filling. Sedimentology 47(s1), 121-178.

Paola, C., Heller, P.L. and Angevine, C.L., 1992. The large-scale dynamics of grain-size variation in alluvial basins, 1: Theory. Basin Research 4(2), 73-90.

Paola, C., and Martin, J.M., 2012. Mass-balance effects in depositional systems. Journal of Sedimentary Research 82, 435-450.

Pearthree, P.A. and House, P.K., 2014. Paleogeomorphology and evolution of the early Colorado River inferred from relationships in Mohave and Cottonwood valleys, Arizona, California, and Nevada.

Geosphere 10, 1139-1160.

Pentecost, A., 2005. Travertine. Springer Verlag, Berlin, 445 p.

Phleger, F.B., 1964. Patterns of living benthonic Foraminifera, Gulf of California-Marine geology of the Gulf of California. American Association of Petroleum Geology, Memoir 3, 377-394.

Posamentier, H.W. and Allen, G.P., 1999. Siliciclastic sequence stratigraphy: concepts and applications, 
Vol. 7. Tulsa: SEPM (Society for Sedimentary Geology).

Posamentier, H.W., Allen, G. P., James, D. P., Tesson, M., 1992. Forced regressions in a sequence stratigraphic framework: concepts, examples, and exploration significance. American Association of Petroleum Geologists Bulletin 76, 1687-1709.

Potter, P.E., 1978. Significance and origin of big rivers. Journal Geology 86, 13-33.

Poulson, S.R. and John, B.E. 2003. Stable isotope and trace element geochemistry of the basal Bouse Formation carbonate, southwestern United States: Implications for the Pliocene uplift history of the Colorado Plateau: Geological Society America Bulletin 115, 434-444.

Prince, P.S., Spotila, J.A. and Henika, W.S., 2011. Stream capture as driver of transient landscape evolution in a tectonically quiescent setting. Geology 39, 823-826.

Raymo, M.E., Hearty, P., De Conto, R., O'Leary, M.J., Dowsett, H.J., Robinson, M.M. and Mitrovica, J.X., 2009. PLIOMAX: Pliocene maximum sea level project. Pages news 17(2).

Reading, H.G., 1986. Sedimentary Environments and Facies. Blackwell Scientific Publications, USA, $2^{\text {nd }}$ edition, $615 \mathrm{p}$.

Repasch, M., Karlstrom, K., Heizler, M. and Pecha, M., 2017. Birth and evolution of the Rio Grande fluvial system in the past $8 \mathrm{Ma}$ : Progressive downward integration and the influence of tectonics, volcanism, and climate. Earth-Science Reviews 168, 113-164.

Resig, J.M., 1974. Recent foraminifera from a landlocked Hawaiian lake. Journal Foraminiferal Research 4, 69-76.

Resig, J.M., 1989. Stratigraphic distribution of Late Neogene species of the planktonic foraminifer Streptochilus in the Indo-Pacific. Micropaleontology 35, 49-62.

Resig, J.M., 1993. Cenozoic stratigraphy and paleoceanography of biserial planktonic foraminifera, Ontong Java Plateau. In: Berger, W.H., editor, Proceedings of the Ocean Drilling Program, Scientific Results 130, 231-244.

Resig, J.M. and Kroopnick, P.M., 1983. Isotopic and distributional evidence of a planktonic habit for the foraminiferal genus Streptochilus Bronnimann and Resig, 1971. Marine Micropaleontology 8, 235-248.

Reynolds, R.E., 2016. Tracks around the Bouse: Where's the beef? In: Reynolds, R.E. (Ed.), 2016. Desert Symposium Field Guide and Proceedings, California State University Desert Studies Center, Zzyzx, CA, 185-188.

Richard, S.M., 1993. Palinspastic reconstruction of southeastern California and southwestern Arizona for the Middle Miocene. Tectonics 12, 830-854.

Romans, B.W., Castelltort, S., Covault, J.A., Fildani, A. and Walsh, J.P., 2016. Environmental signal propagation in sedimentary systems across timescales. Earth-Science Reviews 153, 7-29.

Roskowski, J.A., Patchett, P.J., Spencer, J.E., Pearthree, P.A., Dettman, D.L., Faulds, J.E., and Reynolds, A.C., 2010. A late Miocene-early Pliocene chain of lakes fed by the Colorado River: Evidence from $\mathrm{Sr}, \mathrm{C}$, and $\mathrm{O}$ isotopes of the Bouse Formation and related units between Grand Canyon and the Gulf of California: Geol. Soc. America Bulletin 122, 1625-1636.

Ross, C. P., 1923. The Lower Gila region, Arizona: U.S. Geol. Survey Water-Supply Paper 498, 237 p., 23 plates., 16 figures. 
Sampei, Y., Matsumoto, E., Dettman, D.L., Tokuoka, T., and Abe, O., 2005. Paleosalinity in a brackish lake during the Holocene based on stable oxygen and carbon isotopes of shell carbonate in Nakaumi Lagoon, southwest Japan. Palaeogeography, Palaeoclimatology, Palaeoecology 224, 352- 366.

Sandberg. P. A.. 1966. The modern ostracods Cyprideis bensoni, n. sp. Gulf of Mexico, and C. castus, Baja California. Journal Paleontology 40, 447-449.

Sarna-Wojcicki, A.M., Deino, A.L., Fleck, R.J., McLaughlin, R.J., Wagner, D., Wan, E., Wahl, D., Hillhouse, J.W., and Perkins, M., 2011. Age, composition, and areal distribution of the Pliocene Lawlor Tuff, and three younger Pliocene tuffs, California and Nevada. Geosphere 7, 599-628.

Schiebel, R. and Hemleben, C., 2005. Planktic Foraminifers in the Modern Ocean. Ecology, Biogeochemistry, and Application, Springer, Berlin, 333 p.

Schmitt, A.K., and Vazquez, J.A., 2006. Alteration and re-melting of nascent oceanic crust during continental rupture: Evidence from zircon geochemistry of rhyolites and xenoliths from the Salton Trough, California: Earth and Planetary Science Letters 252, 260-274.

Seiler, C., Fletcher, J.M., Kohn, B.P., Gleadow, A.J. and Raza, A., 2011. Low-temperature thermochronology of northern Baja California, Mexico: Decoupled slip-exhumation gradients and delayed onset of oblique rifting across the Gulf of California. Tectonics 30(3).

Seiler, C., Quigley, M.C., Fletcher, J.M., Phillips, D., Gleadow, A.J.W. and Kohn, B.P., 2013. Stratigraphy and 40Ar/39Ar geochronology of the Santa Rosa basin, Baja California: Dynamic evolution of a constrictional rift basin during oblique extension in the Gulf of California. Basin Research 25(4), 388-418.

Sen Gupta, B.K., Turner, R.E., and Rabalais, N.N., 1996. Seasonal oxygen depletion in continental-shelf waters of Louisiana: Historical record of benthic foraminifers. Geology 24, 227-230.

Sherrod, D.R., and Tosdal, R.M., 1991. Geologic setting and Tertiary structural evolution of southwestern Arizona and southeastern California. Journal Geophysical Research 96, 12,407-12,423.

Shirvell, C., 2006. Pliocene Exhumation along the West Salton Detachment System and Tectonic Evolution of the Fish Creek-Vallecito Supradetachment Basin, Salton Trough, Southern California. Unpubl. M.S. thesis, University of California, Los Angeles, 133 p.

Shirvell, C.R., Stockli, D.F., Axen, G.J., and Grove, M., 2009. Miocene-Pliocene exhumation along the west Salton detachment fault, southern California, from (UTh)/He thermochronometry of apatite and zircon: Tectonics, v. 28, p. TC2006, doi: 10.1029/2007TC002172

Sklar, L. S., and W. E. Dietrich, 2004. A mechanistic model for river incision into bedrock by saltating bed load, Water Resources Research 40, W06301, doi:10.1029/2003WR002496.

Smart, C.W., and Thomas, E., 2006. The enigma of early Miocene biserial planktic foraminifera. Geology 34, 1041-1044.

Smart, C.W., and Thomas, E., 2007. Resig 1971 (Foraminifera) and new species from the lower Miocene of the Atlantic and Indian Oceans. Micropaleontology 53(1-2), 73-103.

Smith, P.B., 1964. Ecology of benthonic species. U.S. Geological Survey Professional Paper 429-B, 55 p.

Smith, P.B., 1970. New evidence for Pliocene marine embayment along the lower Colorado River area, California and Arizona: Geological Society America Bulletin 81, 1411-1420.

Spencer, J.E., and Patchett, P.J., 1997. Sr isotope evidence for a lacustrine origin for the upper Miocene to Pliocene Bouse Formation, lower Colorado River trough, and implications for timing of Colorado Plateau uplift. Geological Society America Bulletin 109, 767-778. 
Spencer, J.E., Peters, L., McIntosh, W.C., and Patchett, P.J., 2001. ${ }^{40} \mathrm{Ar} /{ }^{39} \mathrm{Ar}$ geochronology of the Hualapai Limestone and Bouse Formation and implications for the age of the lower Colorado River, In: Young, R.A., and Spamer, E.E. (Eds.), The Colorado River: Origin and evolution: Grand Canyon, Arizona, Grand Canyon Association Monograph 12, pp. 89-91.

Spencer, J.E., Patchett, P.J., Pearthree, P.A., and House, P.K., Sarna-Wojcicki, A.M., Wan, E., Roskowski, J.A., and Faulds, J.E., 2013. Review and analysis of the age and origin of the Pliocene Bouse Formation, lower Colorado River Valley, southwestern USA. Geosphere 9(3), 444-459.

Spencer, J.E., Pearthree, P.A., and House, P.K., 2008. An evaluation of the evolution of the latest Miocene to earliest Pliocene Bouse lake system in the lower Colorado River valley, southwestern USA, In: Reheis, M.C., Hershler, R., and Miller, D.M. (Eds.), Late Cenozoic drainage history of the southwestern Great Basin and lower Colorado River region: Geologic and biotic perspectives. Geological Society America Special Paper 439, 375-390.

Stanzo, O., and Boer, P. L., 1995. Basin dimensions and morphology as controls on amplification of tidal motions (the Early Miocene North Hungarian Bay). Sedimentology 42, 665-682.

Steely, A.N., 2006. The evolution from late Miocene west Salton detachment faulting to cross-cutting Pleistocene oblique strike slip faults in the SW Salton Trough, Southern California. Unpubl. M.S. thesis, Utah State University, Logan, Utah, 3 plates, $238 \mathrm{p}$.

Stokes, M., Mather, A.E. and Harvey, A.M., 2002. Quantification of river-capture-induced base-level changes and landscape development, Sorbas Basin, SE Spain. Geological Society, London, Special Publications 191, 23-35.

Stouff, V., Geslin, E. Debenay, J.P., Lesourd, M., 1999. Origin of morphological abnormalities in Ammonia (Foraminifera); studies in laboratory and natural environments. Journal Foraminiferal Research 29, 152-170.

Swenson, J.B., Voller, V.R., Paola, C., Parker, G. and Marr, J.G., 2000. Fluvio-deltaic sedimentation: A generalized Stefan problem. European Journal of Applied Mathematics 11, 433-452.

Sinha, R., Bhattacharjee, P.S., Sangode, S.J., Gibling, M.R., Tandon, S.K., Jain, M. and Godfrey-Smith, D., 2007. Valley and interfluve sediments in the southern Ganga plains, India: exploring facies and magnetic signatures. Sedimentary Geology 201, 386-411.

Tandon, S.K. and Sinha, R., 2007. Geology of large river systems. In: Gupta, A. (Ed.), Large rivers: geomorphology and management, John Wiley \& Sons, pp.7-28.

Taylor, D.W., 1983. Late Tertiary mollusks from the Lower Colorado River valley. Ann Arbor, University of Michigan, Contributions from the Museum of Paleontology 26, 289-298.

Todd, T.N., 1976. Pliocene occurrence of the Recent atherinid fish Colpichthys regis in Arizona. Journal Paleontology 50, 462-466.

Turak, J., 2000. Re-evaluation of the Miocene/Pliocene depositional history of the Bouse Formation, Colorado River trough, southern Basin and Range (CA, NV, and AZ). Unpubl. M.S. thesis, University of Wyoming, Laramie, 96 p.

Turowski, J.M., Lague, D. and Hovius, N., 2007. Cover effect in bedrock abrasion: A new derivation and its implications for the modeling of bedrock channel morphology. Journal Geophysical Research: Earth Surface 112(F4).

Twidale, C.R., 2004. River patterns and their meaning. Earth-Science Reviews 67, 159-218.

Van Tassell, J., Ferns, M., McConnell, V., and Smith, G.R., 2001. The mid-Pliocene Imbler fish fossils, Grande Ronde Valley, Union County, Oregon, and the connection between Lake Idaho and the Columbia 
River. Oregon Geology 63, 77-96.

Wade, B.S., Pearson, P.N., Berggren, W.A., Pälike, H., 2011. Review and revision of Cenozoic tropical planktonic foraminiferal biostratigraphy and calibration to the geomagnetic polarity and astronomical time scale. Earth Science Reviews 104, 111-142.

Walton, W.R., 1955. Ecology of living benthonic foraminifera, Todos Santos Bay, Baja California. Journal Paleontology 29, 952-1018.

Winker, C.D., and Kidwell, S.M., 1996. Stratigraphy of a marine rift basin: Neogene of the western Salton Trough, California. In: Abbott, P.L., and Cooper, J.D. (Eds.), Field Conference Guidebook and Volume for the American Association of Petroleum Geologists Annual Convention: American Association of Petroleum Geologists, Bakersfield, California, p. 295-336.

Winker, C.D., 1987. Neogene stratigraphy of the Fish Creek-Vallecito section, southern California: Implications for early history of the northern Gulf of California and the Colorado Delta. Unpubl. Ph.D. thesis, University of Arizona, Tucson, Arizona, $494 \mathrm{p}$.

Winsor, K., Curran, H.A., Greer, L. and Glumac, B., 2012. Unusual Holocene serpulid-tufa bioherms, Enriquillo Valley, Dominican Republic: Morphologies and paleoenvironmental implications. Palaios 27, 693-706.

Winterer, J.I., 1975. Biostratigraphy of Bouse Formation: A Pliocene Gulf of California Deposit in California, Arizona, and Nevada. Unpubl. M.S. thesis, California State University, Long Beach, California, $132 \mathrm{p}$.

Wood, S. H. and Clemens, D.M., 2002. Geologic and tectonic history of the western Snake River Plain, Idaho and Oregon. In: eds. Bonnichsen, B., White, C.M., and McCurry, M., Tectonic and Magmatic Evolution of the Snake River Plain Volcanic Province. Idaho Geological Survey Bulletin 30, Moscow, ID: Idaho Geological Survey Press, pp. 69-103.

Young, H.R., Li, R. and Kuroda, M., 2012. Silicification in Mississippian Lodgepole Formation, northeastern flank of Williston basin, Manitoba, Canada. Journal Earth Science 23, 1-18.

\section{FIGURE CAPTIONS}

Figure 1. Map of the lower Colorado River region showing regional topography and major faults. Surface exposures of the Bouse are indicated in yellow; paleolake maximum elevations are from Spencer et al. (2008; 2013). "Paleo-lake Blythe" lies at the center of debate over lake versus marine-estuary environments of the southern Bouse Formation. Red dots show wells that encountered Bouse Formation in the subsurface (Metzger et al., 1973). White lines south of Yuma are subsurface structure contours showing elevation (in feet) of the top of the Bouse Formation; pink line is inferred margin of the Bouse Formation at depth (Olmsted et al., 1973). Places: BP, Buzzards Peak; C, Cibola; CM, Chocolate Mts.; CV, Chemehuevi Valley; DM, Dead Mts.; FB, Fortuna basin; FCVB, Fish Creek - Vallecito basin; FM, Frenchman Mt; LC, Lost Cabin Wash; MM, Mesquite Mt; MW, Milpitas Wash; NIH, northern Indio Hills; NM, Newberry Mts.; OW, Osborne Wash; P, Parker; PVM, Palo Verde Mts; SC, Silver Creek; SGP, San Gorgonio Pass; SP, Secret Pass; SM, Split Mountain Gorge; ST, Salton Trough; Y, Yuma; WW, Whitewater Canyon. Faults: AF, Altar fault; CPF, Cerro Prieto fault; ECSZ, eastern CA shear zone; EF, Elsinore fault; GF, Garlock fault; SAF, San Andreas fault; SJF, San Jacinto fault.

Figure 2. Schematic diagram showing the subsystems of erosion, transfer, and sedimentation as applied to the Colorado River. Modified from Castelltort and Van Den Driessche (2003).

Figure 3. Stratigraphy and geology of the southern Bouse Formation. A. Stratigraphic nomenclature of previous studies and this study ( ${ }^{*}$ refs: Metzger, 1968; Buising, 1988, 1990). B. Geologic map compiled from Sherrod and Tosdal (1991) and Richard (1993), showing map units and location of measured 
sections (Figs. 8-11). "Qal and Qt" is Quaternary alluvium and terrace deposits (undifferentiated). PVP is Palo Verde point. White line is line of stratigraphic panel in Fig. 12; dashed white lines show projection of sections into the panel. Location of map is shown in Fig. 1. C. Conceptual stratigraphic diagram for the southern Bouse Formation, schematically illustrating stratal wedge architecture and thickness variations from basin margins where Bouse Formation is exposed to equivalent thick subsurface deposits beneath the modern Colorado River floodplain (e.g., Homan, 2014; Dorsey et al., 2017).

Figure 4. Field photos of representative lithofacies in the basal carbonate member, southern Bouse Formation. A. Travertine with massive mounds and columnar structures typical of spring-fed carbonate deposits. B. Tabular cross-bedded conglomerate and calcareous pebbly sandstone of the bioclastic facies, illustrating well sorted and moderately rounded clasts in inversely graded pebble foresets bounded by white sandy calcarenite bottomsets and topsets. C. Flaser bedding in wave-ripple laminated sandy calcarenite (grainstone) of the bioclastic facies, indicative of tidal processes and environment. Recessive thin beds are carbonate mud drapes. D. Bedding-plane exposure of Thalassinoides burrows in sandy calcarenite. E. Bimodal bi-directional cross-bedding in coarse bioclastic grainstone of the bioclastic facies; arrows indicate reversing current directions. Inset shows rhodolites consisting of small bivalve shells heavily encrusted with coralline red algae. F. 1.3-m high cross-bed set in well sorted sandy bioclastic grainstone. Smaller-scale cross-bedding on right (circled) records reversing flow direction and migration of subsidiary ripples up the foresets of meter-scale tidal dune bedform. Dashed line highlights foresettopset contact. G. Example of thin- to very thin-bedded lime mudstone (marl) in upper marl unit of the basal carbonate member. Hammer is $32.5 \mathrm{~cm}$ long; pen is $13.7 \mathrm{~cm}$ long.

Figure 5. Typical exposures of the siliciclastic member, southern Bouse Formation. A. Base of green claystone resting on upper contact of fine-grained marl in eastern Milpitas Wash (Fig. 3B). Dark green thin bed (DCL) is "distinctive clay layer" (e.g., Bright et al., 2016). B. Thin-bedded red mudstone and siltstone with desiccation cracks and vertical rhizoliths (calcified root casts) indicating weak soil development. C. Thick-bedded, multistorey trough cross-bedded channel sandstone with vertically stacked and nested 1- to 2.5-m high cross-bed sets. D. Large-scale cross-bedded Colorado River sandstone in lower Hart Mine Wash, showing composite fluvial bedforms and channel geometries including a small mud-filled channel. Sandstone is cut on left by northeast-dipping normal or oblique fault (Dorsey et al., 2017). Hammer is $32.5 \mathrm{~cm}$ long.

Figure 6. Lithofacies of the Bouse upper bioclastic member. A. Micrite (lime mud) in western Milpitas Wash, with desiccation cracks. B. Sandy calcarenite with abundant mollusk, barnacle, and calcareous algae fragments. C-E. Coarse pebbly calcarenite with convex-up wave-formed ripple cross-bedding. In E, estimated ripple wavelengths are: (1) $0.25 \mathrm{~m}$, (2) $1.1 \mathrm{~m}$, (3) $1.5 \mathrm{~m}$, (4) $1.8 \mathrm{~m}$, (5) $2.6 \mathrm{~m}$. Up-section increase in wavelength, for similar grain size, records an increase in water depth through this interval. Hammer is $32.5 \mathrm{~cm}$ long. F. Calcareous-matrix pebble conglomerate with rounded and well rounded clasts interpreted as the deposits of a high-energy fan-delta front, overlain by less calcareous conglomerate with more angular clasts at the conformable transition from upper bioclastic member to overlying alluvial-fan conglomerate.

Figure 7. Fossils in the upper bioclastic member of the southern Bouse Formation. A. Bedding-plane slab of pebbly calcarenite with fossils labeled: $\mathrm{Ba}$, barnacles; $\mathrm{Bi}$, abraded bivalve shells; $\mathrm{Bi}(\mathrm{e})$, bivalve shells encrusted with barnacles and calcareous algae; $\mathrm{H}$, calcareous green algae Halimeda; R, rhodoliths (coralline red algae). Inset shows detail of intact small bivalve (likely Polymesoda or Macoma). B. Halimeda preserved as a clast in pebbly calcarenite. C. Halimeda specimen with distinctive branching segmented thallus and holdfast at base. D. Photomicrograph of Halimeda in C, oriented transverse to the thallus, showing diagnostic internal structures including loosely packed filaments in the interior medulla (filled with sparry calcite), densely packed cortex, and thin outer coating (utricles). E. Concentration of insitu bivalves (Macoma or Mulinia) on bedding plane surface in sandy calcarenite, western Milpitas Wash (Fig. 3B).

Figure 8. Measured sections and stratigraphic relations in the southern Bouse Formation southeast of Cibola, Ariz., modified from Homan (2014) (section locations shown in Fig. 3B). Sections are projected into an east-west panel, distances are approximate. Lateral thickness changes and correlations of stratal 
surfaces are representative of stratigraphic architecture in the southern Bouse Formation. A. Hart Mine Wash composite section, compiled from Homan (2014) (see also Bright et al., 2016, their Fig. 4). Stratigraphic range of samples studied by Bright et al. (2016) is indicated on left; DCL is "distinctive clay layer". B. Upper Marl Wash. C. Big Fault Wash. D. Microfossil data showing abundances (percent total foraminiferal fauna, tick marks indicate 10\% intervals) of the dominant species in each biofacies, plotted in composite section. Environmental constraints for each biofacies are given in Table 2. Bathymetric curve shown on right $(S=$ saline lake; $N$ = neritic, 0-150 m; UB = upper bathyal, $150-500 \mathrm{~m}$ ).

Figure 9. Palo Verde Mountains composite section (location shown in Fig. 3B). The upper marl unit of the basal carbonate member is absent here but is present beneath green claystone in nearby correlative sections located farther east, closer to the basin axis.

Figure 10. Two measured sections in western Milpitas Wash, modified from Homan (2014), where the siliciclastic member is missing and upper bioclastic member rests unconformably on marl of the basal carbonate member. Locations shown in Fig. 3B. A. Section C13 (MiW1). UBM is upper bioclastic member. B. Microfossil data for Section C13 showing abundances of the dominant species (percent total foraminiferal fauna) in each biofacies. Environmental constraints of biofacies are given in Table 2. C. Close-up view of unconformity at base of the upper bioclastic member, showing a karst fissure filled with sandy carbonate from the overlying karst breccia, and karst breccia which is seen to disrupt bedding in the marl. The base of UBM is a gently undulating erosional unconformity with rounded clasts of silicified carbonate reworked out of the underlying marl and entrained as a small-pebble lag along the contact. The basal $\sim 14 \mathrm{~cm}$ of UBM is well sorted, stratified and compositionally segregated sandy calcarenite and calcareous coarse-grained sandstone. Pen is $13.7 \mathrm{~cm}$ long. D. Section C27 (MiW2).

Figure 11. Two measured sections near Buzzards Peak (locations shown in Fig. 3B). Fine-grained carbonate overlying the 4.83-Ma Lawlor Tuff is inferred to correlate to fine-grained carbonate facies of the Bouse upper bioclastic member farther east. No foraminifers were observed in these samples. See text for discussion.

Figure 12. Stratigraphic panel for the southern Bouse Formation, with measured sections hung from base of the upper bioclastic member (see line of panel in Fig. 3B). Horizontal distances are approximate; vertical scale is expanded in sections BP1, BP2, and C27 to show very thin units. Panel does not attempt to display accurate structural geometries, which are too complex in 3-D to represent correctly at this scale (see Dorsey et al., 2017). The siliciclastic member thickens under the modern Colorado River channel as a result of syn-Bouse subsidence along the basin axis, prior to deposition of the upper bioclastic member. Siliciclastic member is missing west and east of the modern river due to subtle syn-Bouse uplift and erosion in those areas.

Figure 13. Sequence stratigraphic interpretation for the southern Bouse Formation.

Figure 14. Interpretation of depositional environments and structural controls on regional stratal architecture the southern Bouse Formation.

Figure 15. Stratigraphy, detrital zircons, and micropaleontology of the Fish Creek - Vallecito basin (FCVB), western Salton Trough. Location shown in Fig. 1. A. Lower 2,500 meters of the FCVB section, modified from Dorsey et al. (2011). First and last occurrences of key foraminiferal species shown. FOD is first occurrence datum, oldest age possible for the species indicated. LOD is last occurrence datum; youngest age possible for the species indicated. GPTS is geomagnetic polarity timescale (Gradstein et al., 2012). B. Detrital- zircon ages (cumulative probability) for Plio-Pleistocene sandstones in the FCVB section, modified from Kimbrough et al. (2015), showing contrast between locally-derived and ColoradoRiver derived populations. C. Biofacies analysis of foraminiferal assemblages and smoothed bathymetric curve, showing percent of species and upper depth limits in each biofacies. Bathymetric curve indicates probable water depth during deposition. Ages of Wind Caves and Mud Hills members based on planktic foraminifers (A.Y. Miranda-Martínez, personal communication, 2017) are consistent with independently determined ages based on correlation of magnetic reversals to the GPTS (Dorsey et al., 2011). Sample locations and metadata available in Dorsey et al. $(2007,2011)$. 
Figure 16. Measured section in the Wind Caves member of the Latrania Formation, lower part of FCVB section (Fig. 15), and photomicrographs showing contrast between locally-derived and Colorado Riverderived sandstones. Paleomagnetic sample sites (bold numbers) from Dorsey et al. (2011): closed circles are normal-polarity, open circles are reversed polarity. Abrupt change from locally-derived to Colorado River-derived sandstones with syntaxial quartz overgrowths coincides with abrupt change from locallyderived to Colorado River-derived detrital zircons (Fig. 15; Kimbrough et al., 2015).

Figure 17. Field photos of sedimentary rocks in the Fish Creek - Vallectio basin. A. Channelized sandrich turbidites in the Wind Caves member of the Latrania Formation. B. Gently dipping interval from upper part of Wind Caves member through Coyote Clay unit of Mud Hills member, to lower part of Yuha member marine deltaic succession. C. Large-scale cross-bedded Colorado River channel sandstones and overbank mudstones of the Arroyo Diablo Formation.

Figure 18. Chronostratigraphy highlighting correlations between the Salton Trough (Fish Creek - Vallecito Basin), San Luis-Fortuna basins (Yuma area), Whitewater Canyon (San Gorgonio Pass), and lower Colorado River valley. Locations shown in Figure 1 and 19. References for Lawlor Tuff (LT) age constraints: (1) Sarna-Wojcicki et al. (2011); (2) Harvey (2014).

Figure 19. Interpreted history of late Miocene to early Pliocene sedimentation in the lower Colorado River and Salton Trough region, drafted on tectonic reconstructions modified from Bennett et al. (2016b). A. Imperial marine basin and southern Bouse Formation from 6.3 to $5.4 \mathrm{Ma}$, during marine incursion and regional transgression. B. Earliest through-flowing Colorado River and delivery of river sand to the Imperial marine basin (Wind Caves member, western Salton Trough) between $\sim 5.3$ and 5.1 Ma. C. Shutdown of sand delivery to the basin and re-flooding of the lower Colorado River valley by a large shallow marine embayment at about 5.0 Ma. D. By 4.0 Ma the Colorado River delta prograded back down the river valley, filling the Salton Trough with fluvial deposits (Arroyo Diablo Formation) and pushing the shoreline southward into the northern Gulf of California. Abbreviations: FCVB, Fish Creek - Vallecito basin; N.I.H., northern Indio Hills; PVP, Palo Verde Point (Fig. 3B); SMG, Split Mountain Gorge; WW, Whitewater Canyon; WSDF, West Salton detachment fault; Y, Yuma, Ariz.; other abbreviations explained in Figure 1.

Figure 20. Comparison of depositional and age models for the southern Bouse Formation, modified from Fig. 19. A. Deposition of basal carbonate in a tide-dominated marine embayment at the north end of the Gulf of California from $\sim 6.3$ to $5.4 \mathrm{Ma}$ (O'Connell et al., 2017; this study), followed by rapid progradation of the Colorado River delta and earliest fluvial channel network by $\sim 5.3 \mathrm{Ma}$. B. Hypothesis for an inland saline lake isolated from the sea by a paleodam in the southern Chocolate Mountains (e.g., Spencer and Patchett, 1997). According to the inland-lake hypothesis, the southern Bouse Formation accumulated in less than 50,000 years during the time window bracketed by ${ }^{40} \mathrm{Ar}-{ }^{39} \mathrm{Ar}$ ages of plagioclase in the Lawlor Tuff in northern California $(4.834 \pm 0.011 \mathrm{Ma})$, and all marine faunas in the southern Bouse Formation were introduced to the large southern lake by birds.

Figure 21. Comparison of chronostratigraphy from 7 to $4 \mathrm{Ma}$ in the Salton Trough and lower Colorado River valley to the global eustatic sea-level curve (Miller et al., 2011). The comparison provides powerful insights into controls on base-level change and sediment discharge during initiation and early evolution of the Colorado River. See text for discussion. 


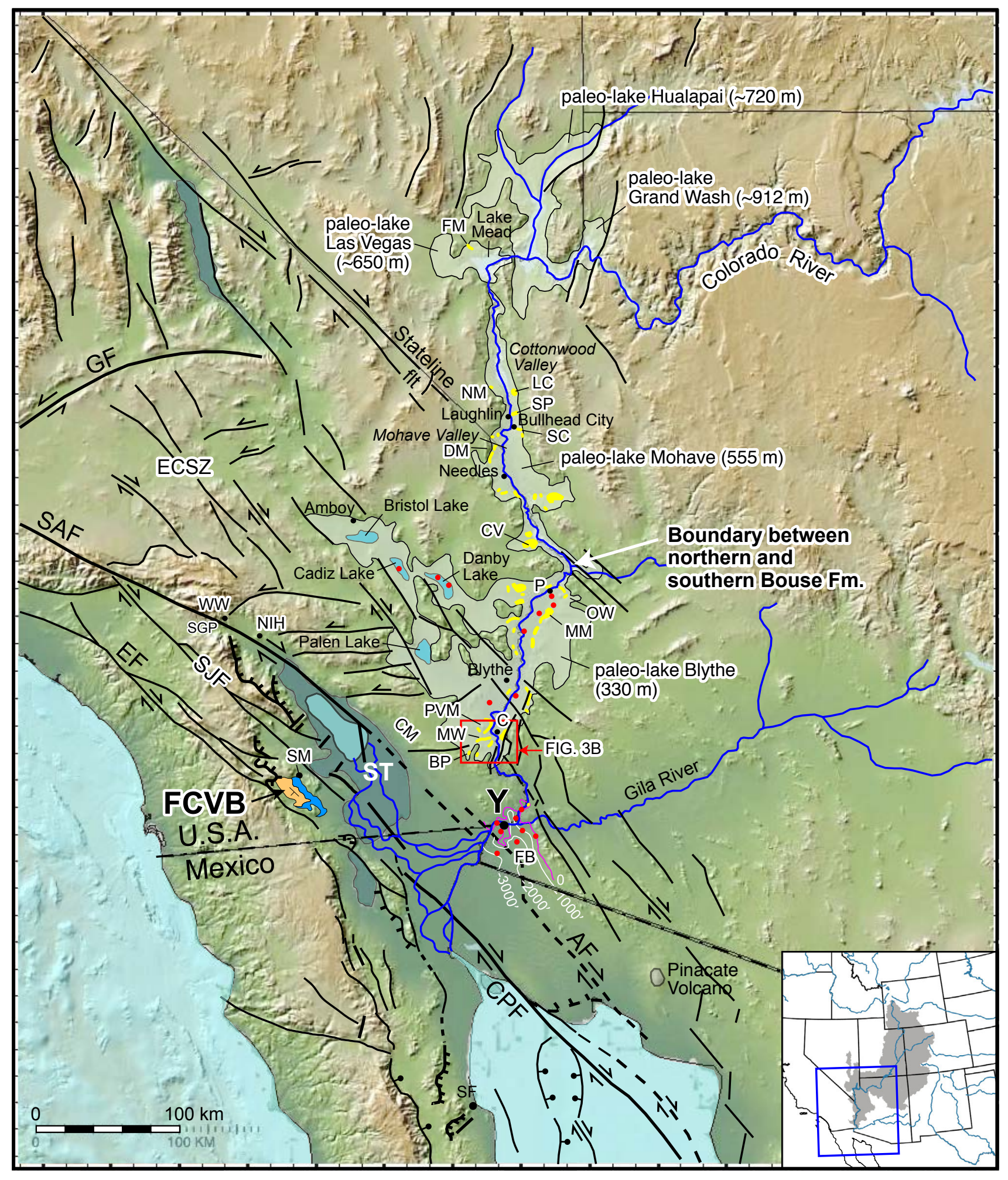

Figure 1 


\section{SUBSYSTEMS of the COLORADO RIVER}

\section{Erosion}

(Colorado Plateau \& Grand Canyon:

$=$ Sediment Source)
Transfer

(lower Colorado

River Valley,

$\sim 400 \mathrm{~km}$ )
Sedimentation

(Salton Trough:

Plate Boundary

Oblique-Rift Basin)

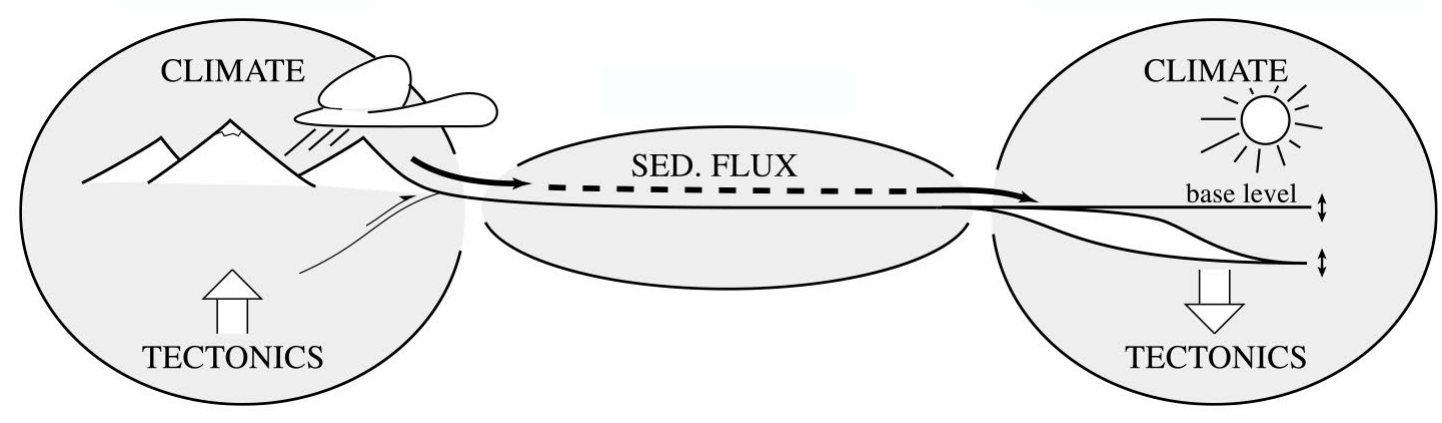

Figure 2 


\begin{tabular}{|c|c|c|c|}
\hline A $\begin{array}{l}\text { Previous } \\
\text { Studies * }\end{array}$ & \multicolumn{2}{|r|}{ THIS STUDY } & LITHOLOGY \\
\hline Bullhead Alluvium & \multicolumn{2}{|r|}{ Bullhead Alluvium } & \\
\hline Not Recognized & \multicolumn{2}{|c|}{ Upper Bioclastic Mbr } & \\
\hline \multirow{3}{*}{$\begin{array}{l}\text { Interbedded } \\
\text { Unit }\end{array}$} & \multirow{3}{*}{ 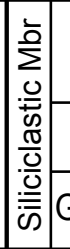 } & $\begin{array}{l}\text { Colorado River } \\
\text { Sandstone }\end{array}$ & \\
\hline & & Red Mudstone & \\
\hline & & Green Claystone & ๓ \\
\hline \multirow{2}{*}{$\begin{array}{c}\text { Basal } \\
\text { Carbonate }\end{array}$} & \multirow{2}{*}{ 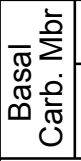 } & ב & \multirow{4}{*}{ 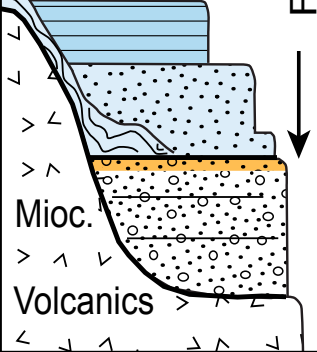 } \\
\hline & & $\begin{array}{ll}\dot{2} \\
\overline{0} \\
\dot{5}\end{array}$ & \\
\hline $\begin{array}{c}\text { Miocene } \\
\text { Fanglomerate }\end{array}$ & & $\begin{aligned} & \text { Miocene } \\
\text { Eanglomerate } & \end{aligned}$ & \\
\hline \multicolumn{3}{|c|}{ Miocene Volcanic Rocks } & \\
\hline
\end{tabular}
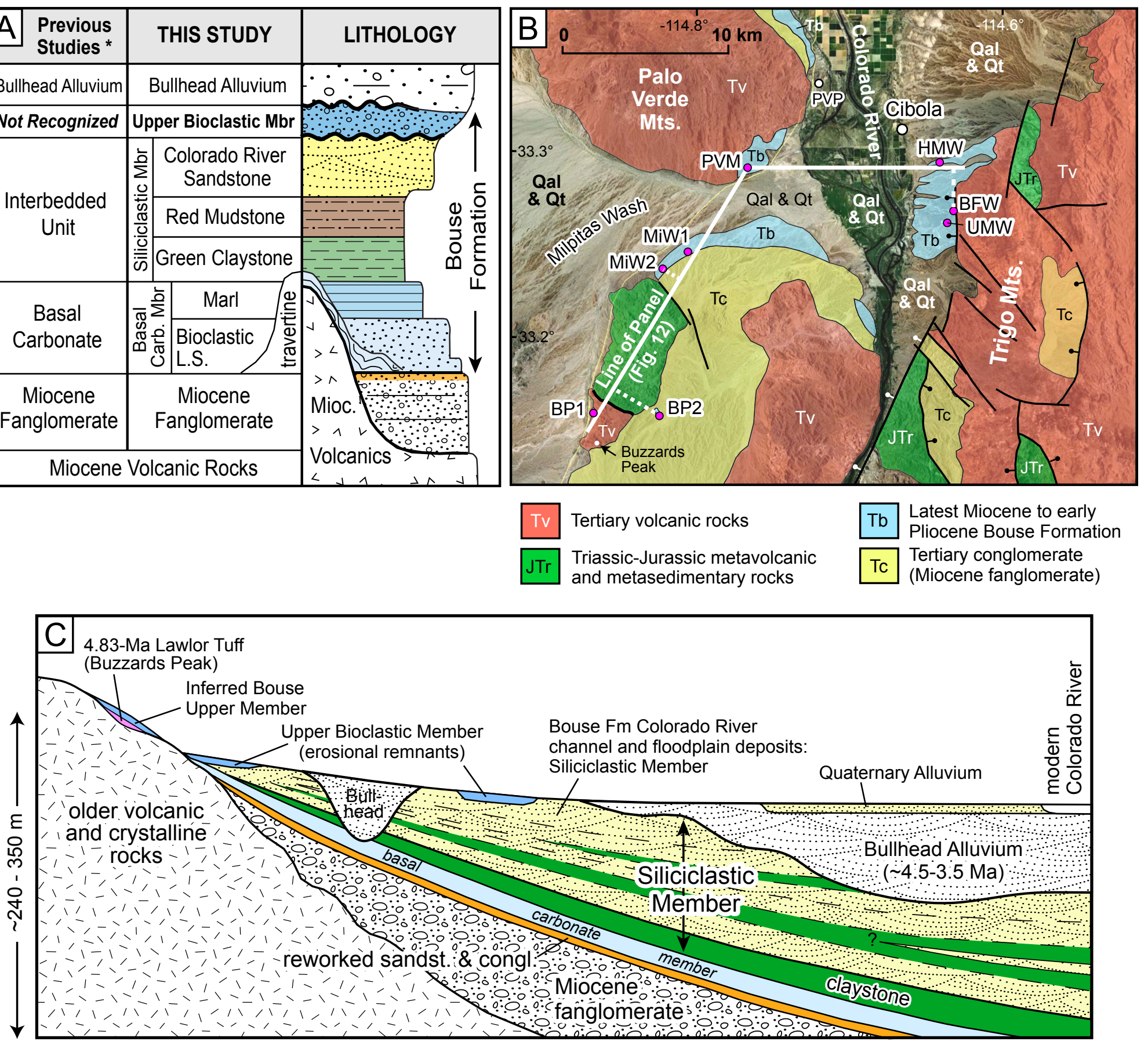

Figure 3 

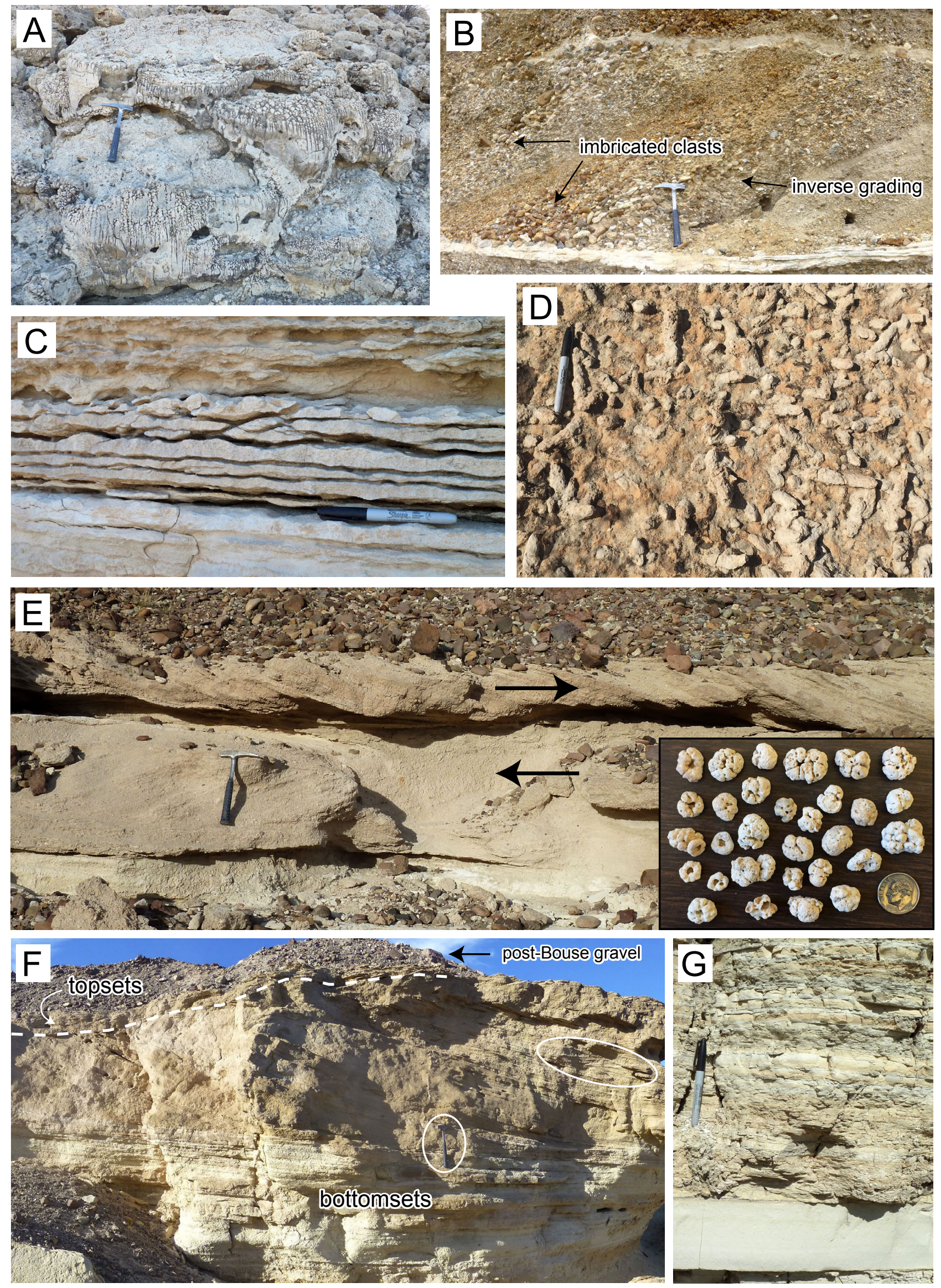

Figure 4 

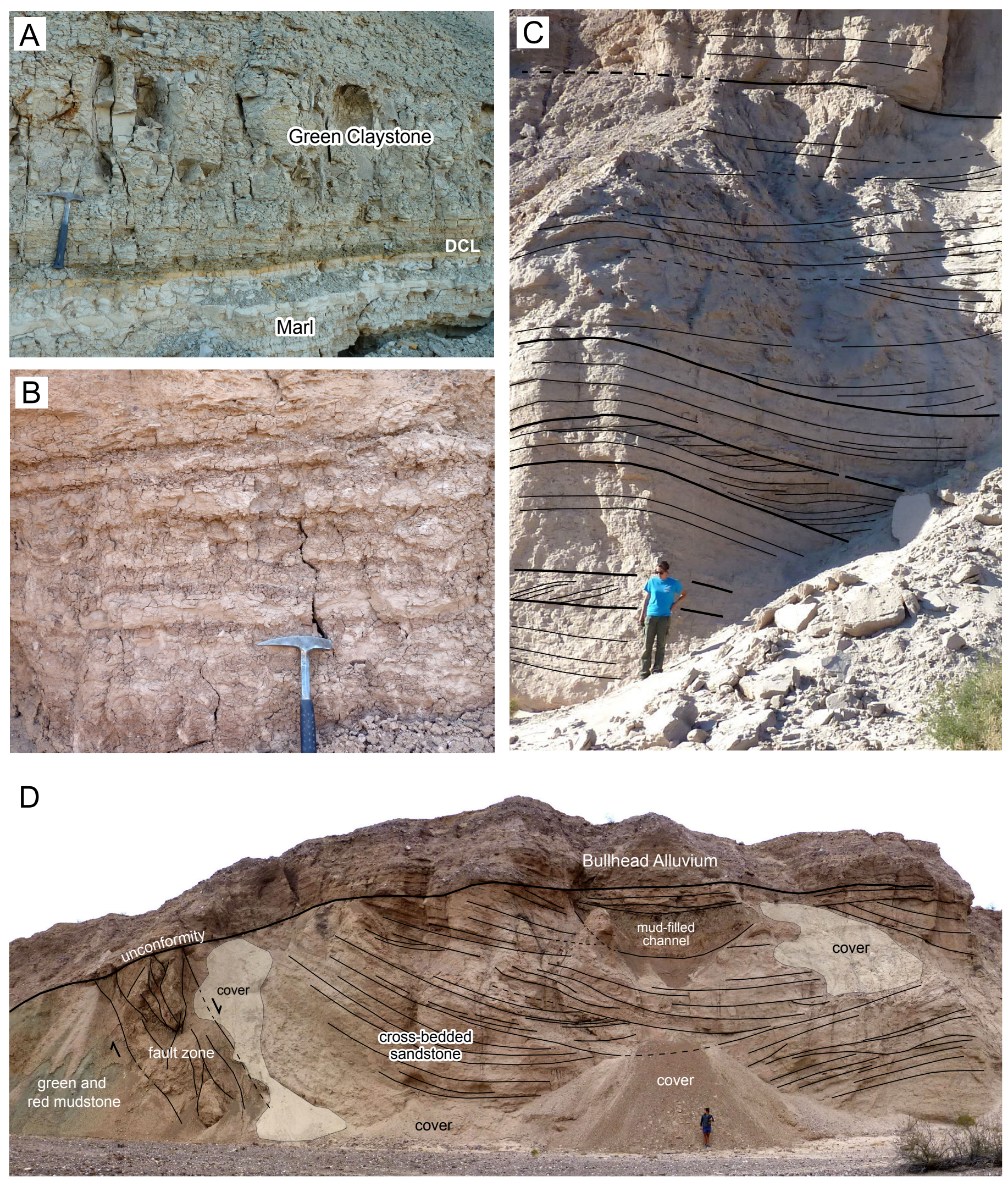

Figure 5 

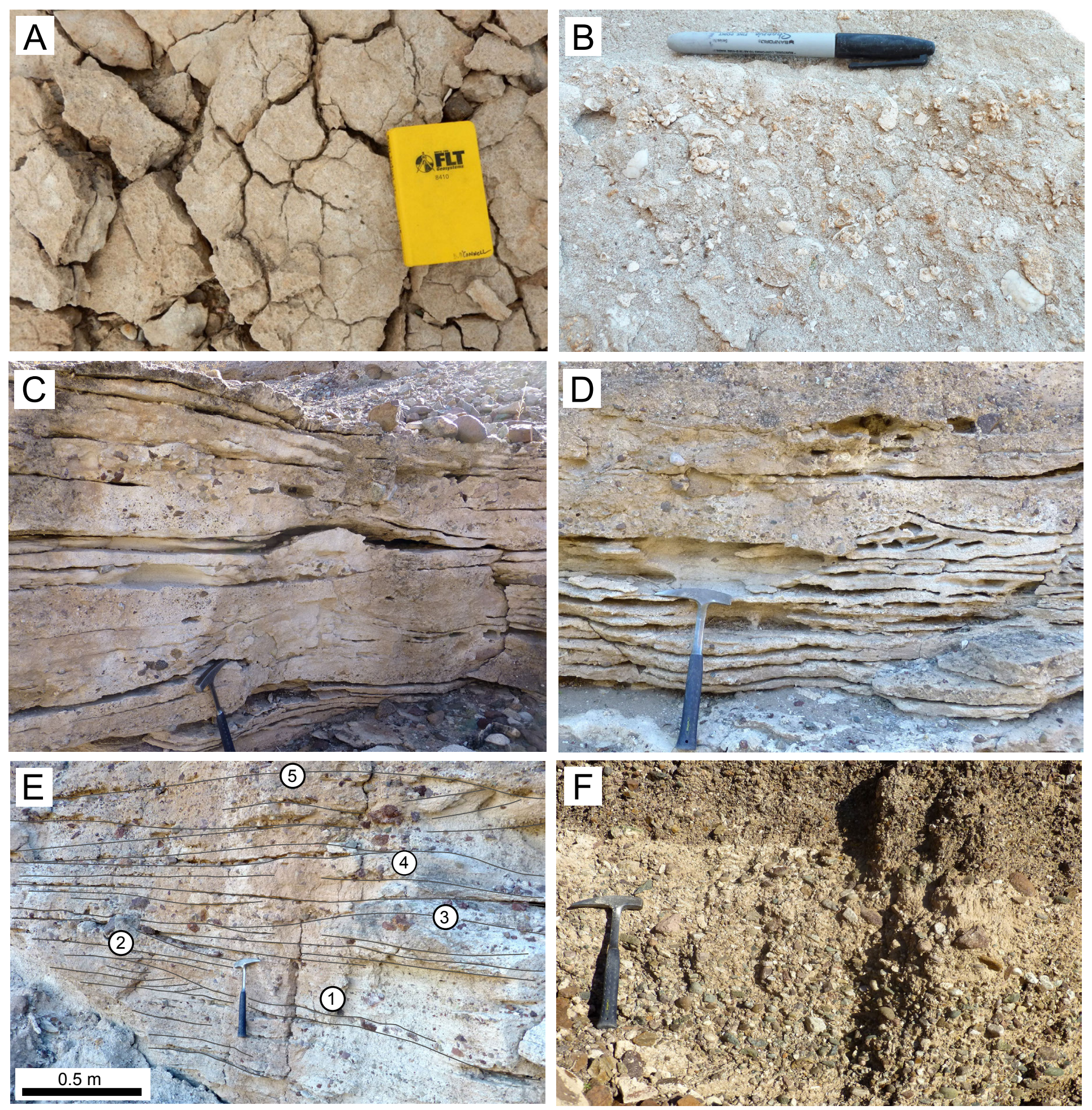

Figure 6. Lithofacies of the Bouse upper bioclastic member. A. Micrite (lime mud) with desiccation cracks. B. Sandy calcarenite with abundant mollusk, barnacle, and calcareous algae fragments. C-E. Coarse pebbly calcarenite with flat-based, convex-up wave-formed ripple cross-bedding. In E, estimated ripple wavelengths are: (1) $0.25 \mathrm{~m}$, (2) $1.1 \mathrm{~m}$, (3) $1.5 \mathrm{~m}$, (4) $1.8 \mathrm{~m}$, (5) $2.6 \mathrm{~m}$. Up-section increase in wavelength (for similar grain size) records increase in water depth through this interval. Hammer is $32.5 \mathrm{~cm}$ long. F. Calcareous-matrix pebble conglomerate with rounded and well rounded clasts interpreted as the deposits of a high-energy fan-delta front, overlain by less calcareous conglomerate with more angular clasts at conformable transition from upper bioclastic member to overlying alluvial-fan conglomerate. 

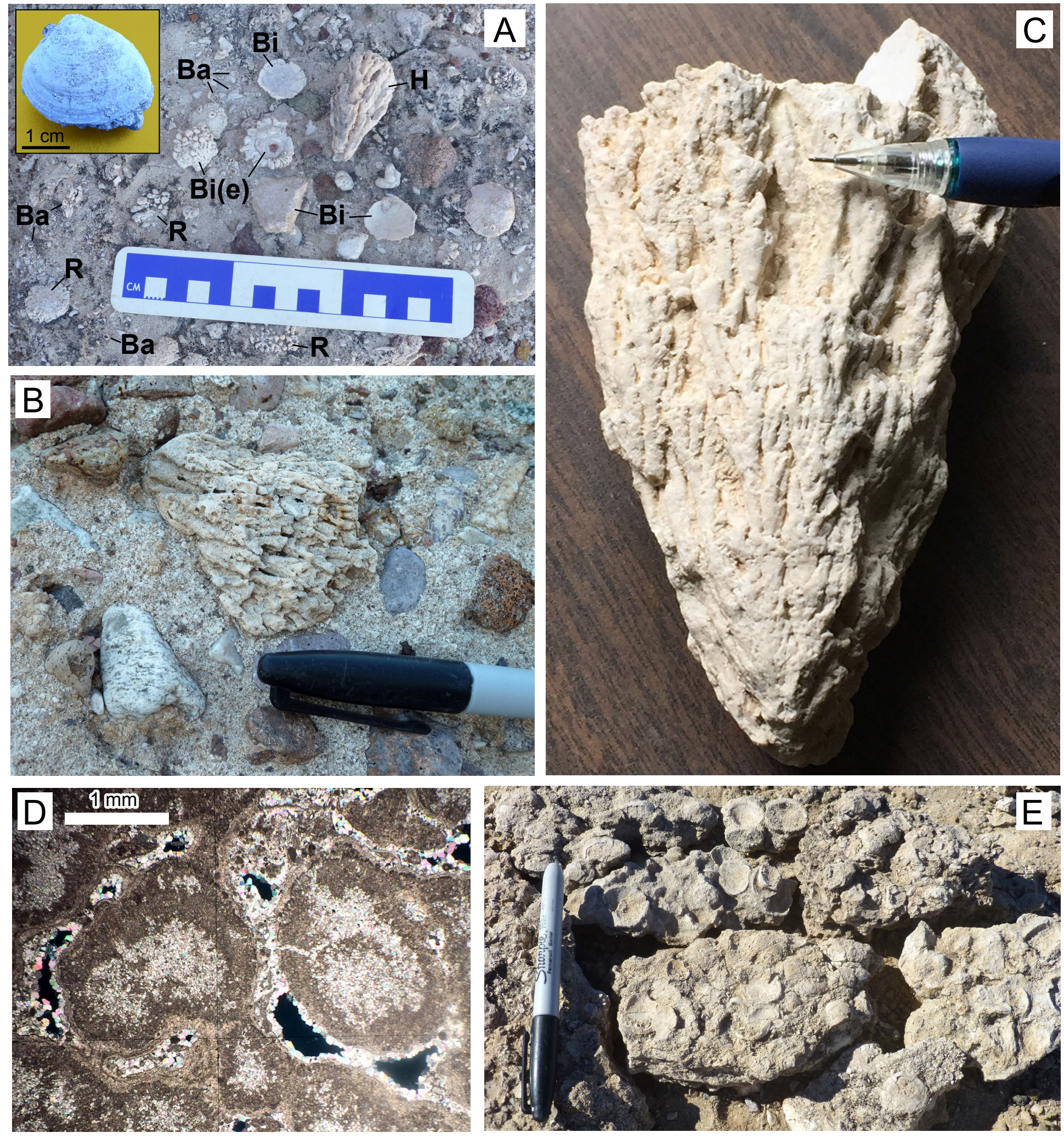

Figure 7. Fossils in the upper bioclastic member of the southern Bouse Formation. A. Bedding-plane slab of pebbly calcarenite with fossils labeled: $\mathrm{Ba}$, barnacles; $\mathrm{Bi}$, abraded bivalve shells; $\mathrm{Bi}(\mathrm{e})$, bivalve shells encrusted with barnacles and calcareous algae; $\mathrm{H}$, calcareous green algae Halimeda; $\mathrm{R}$, rhodoliths (coralline red algae). Inset shows detail of intact small bivalve (likely Polymesoda). B. Halimeda preserved as a clast in calcarenite-matix rich pebble conglomerate. C. Halimeda specimen with distinctive branching segmented thallus and holdfast at base. D. Photomicrograph of Halimeda oriented transverse to the thallus showing diagnostic internal structures, including loosely packed filaments in the interior medulla (filled with sparry calcite), densely packed cortex, and thin outer coating (utricles). E. Concentration of bivalves (Macoma or Mulinia) in sandy calcarenite. 


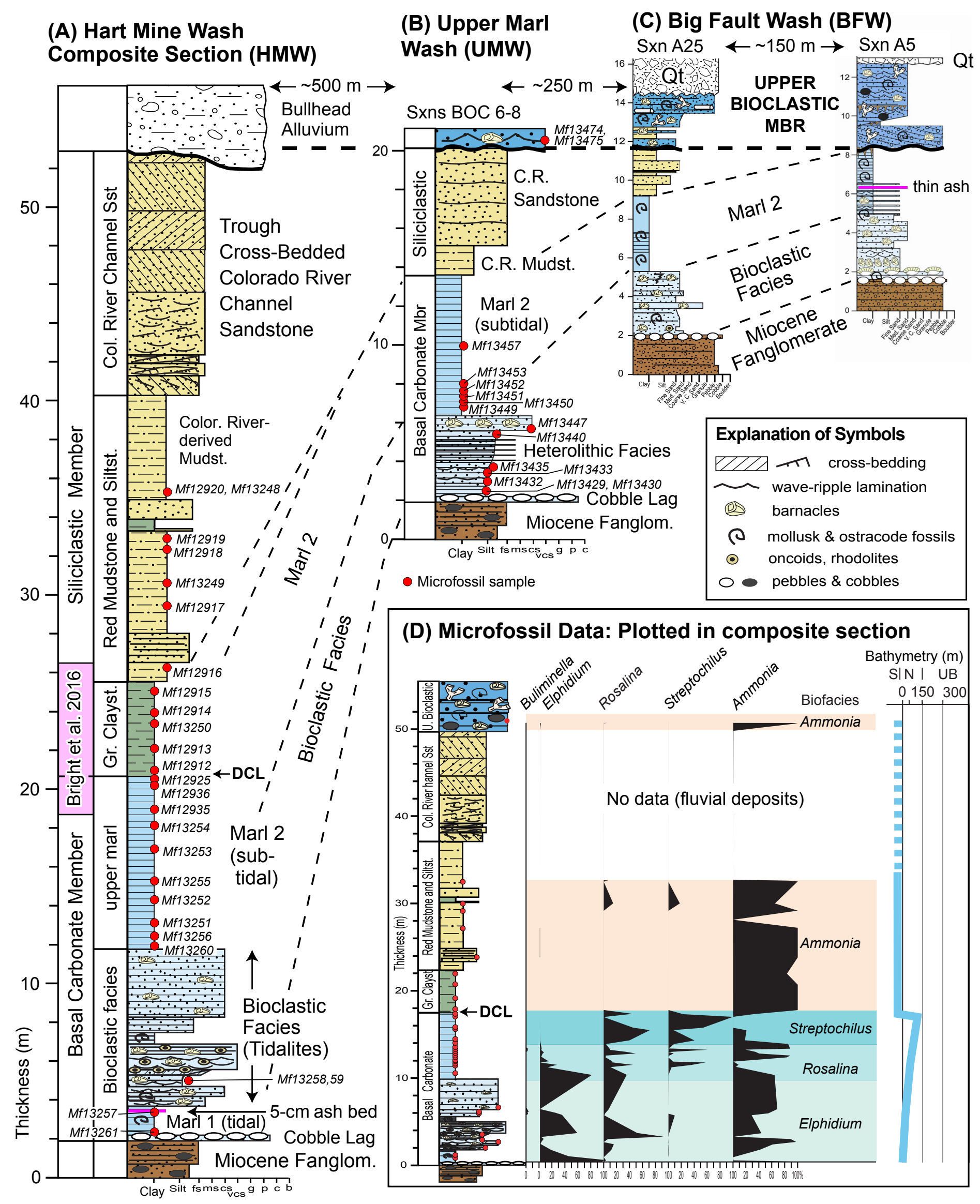

Figure 8 


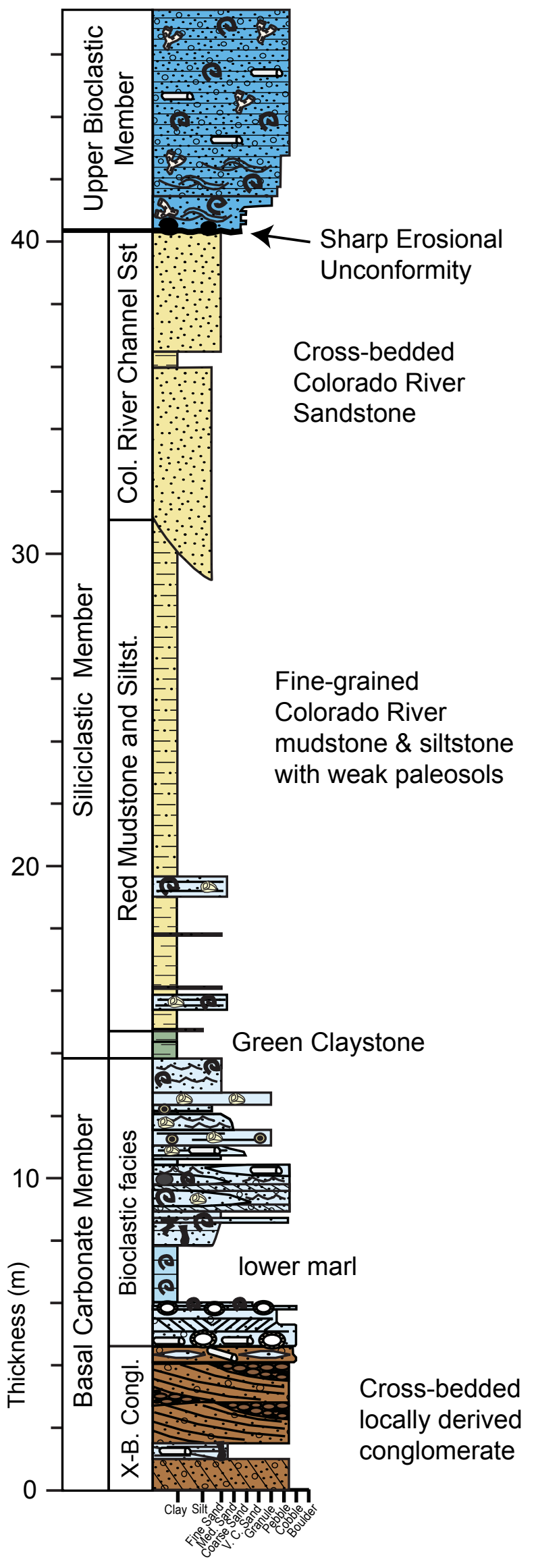

Figure 9 


\section{(A) Section C13 (MiW1)}

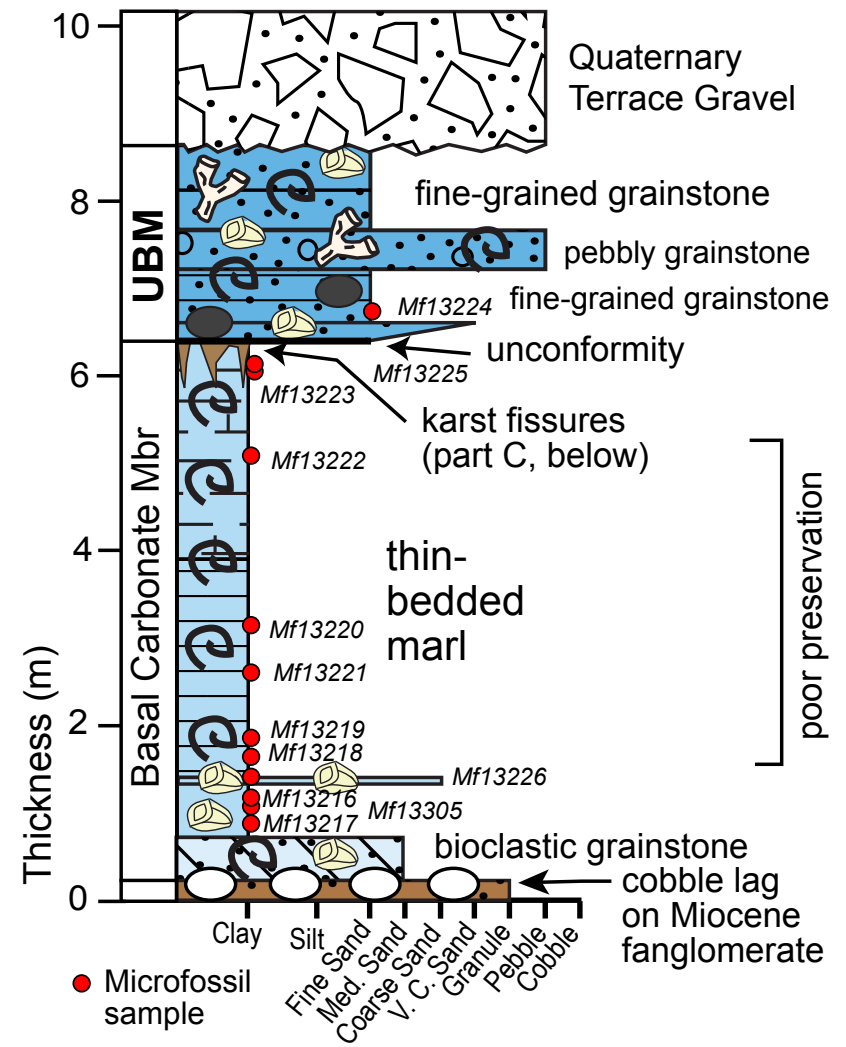

(C) Karst breccia and fissure, Section C13

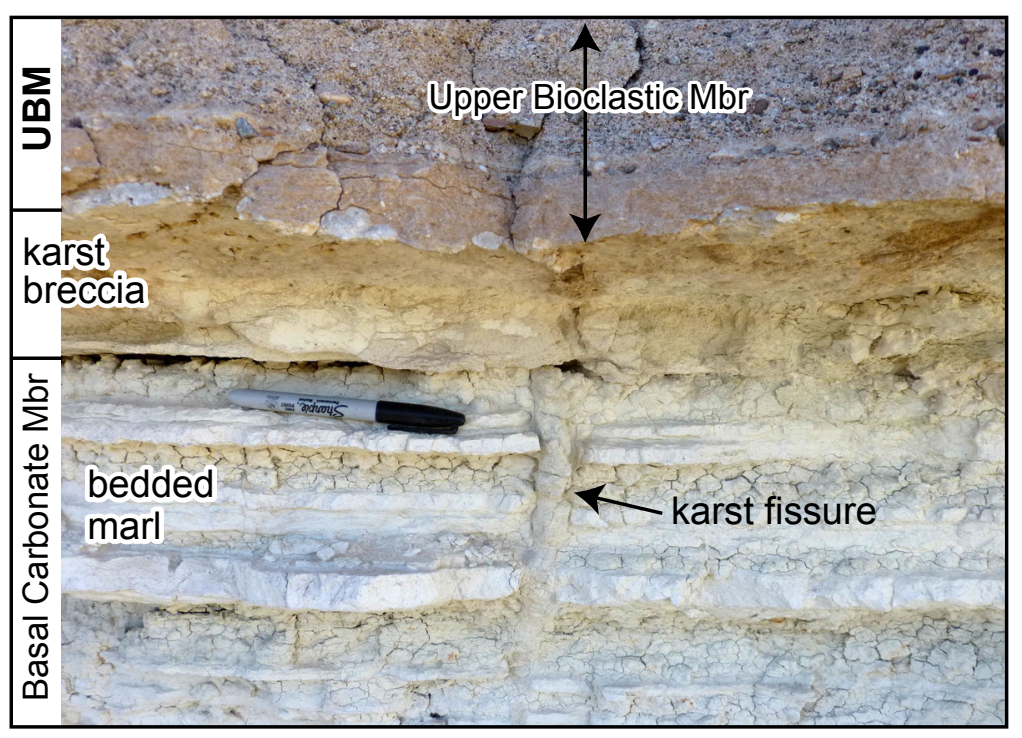

(B) Microfossil data, Section C13

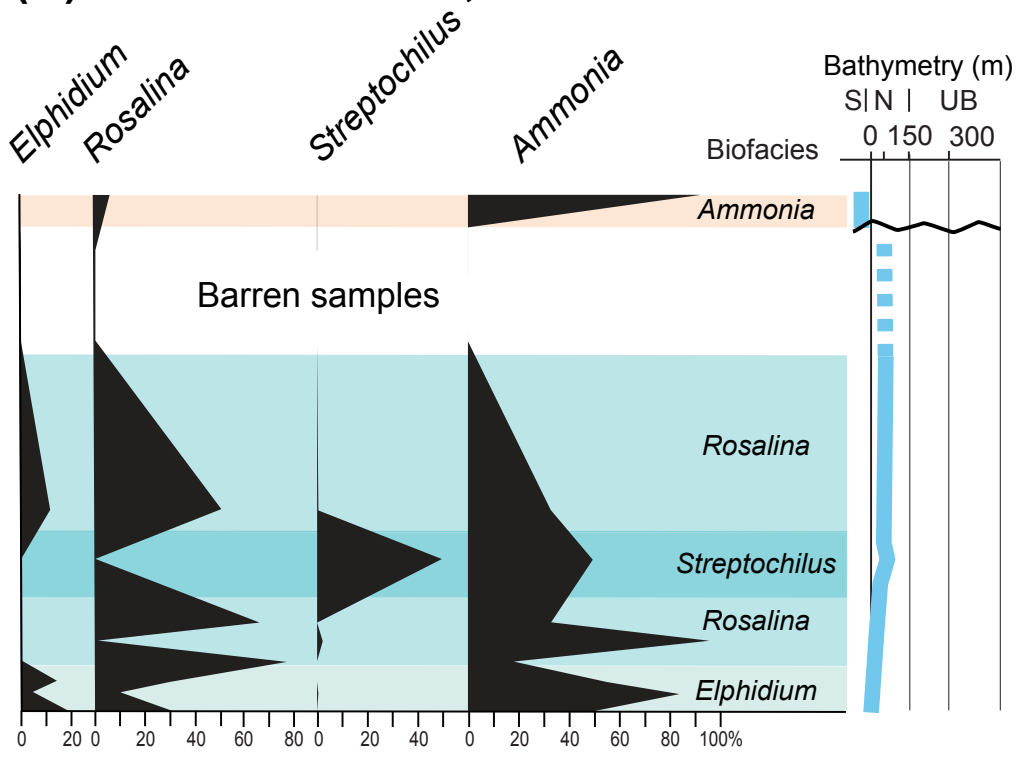

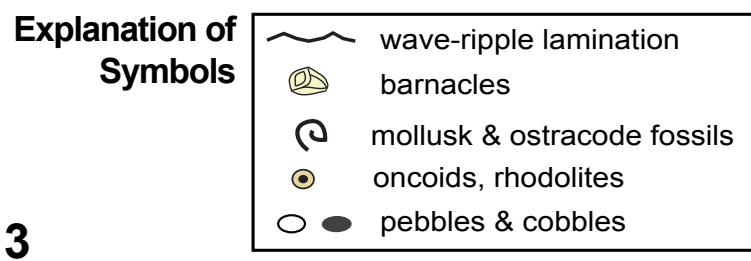

(D) Section C27 (MiW2)

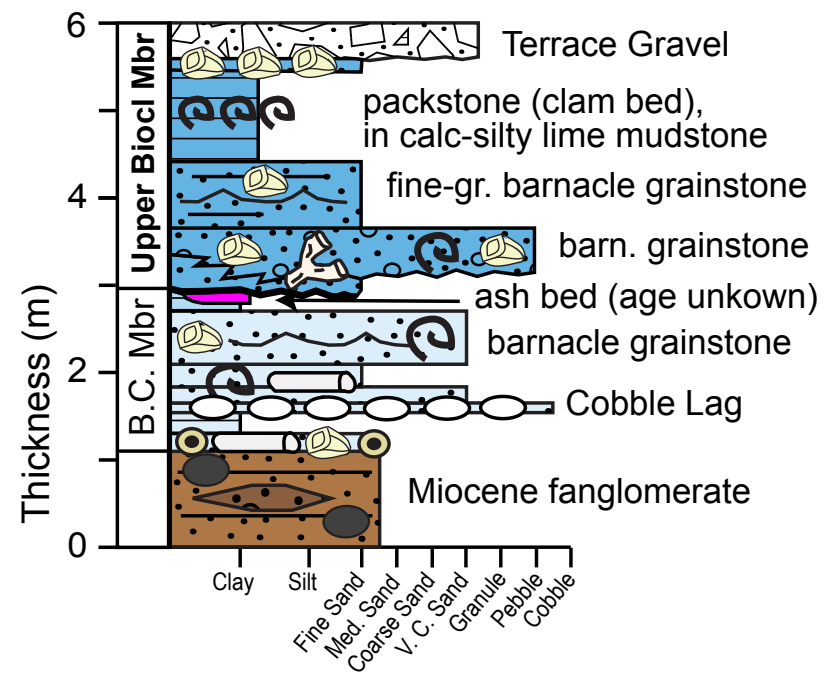

Figure 10 


\section{(A) Section BP1:}

\section{north of Buzzards Peak}

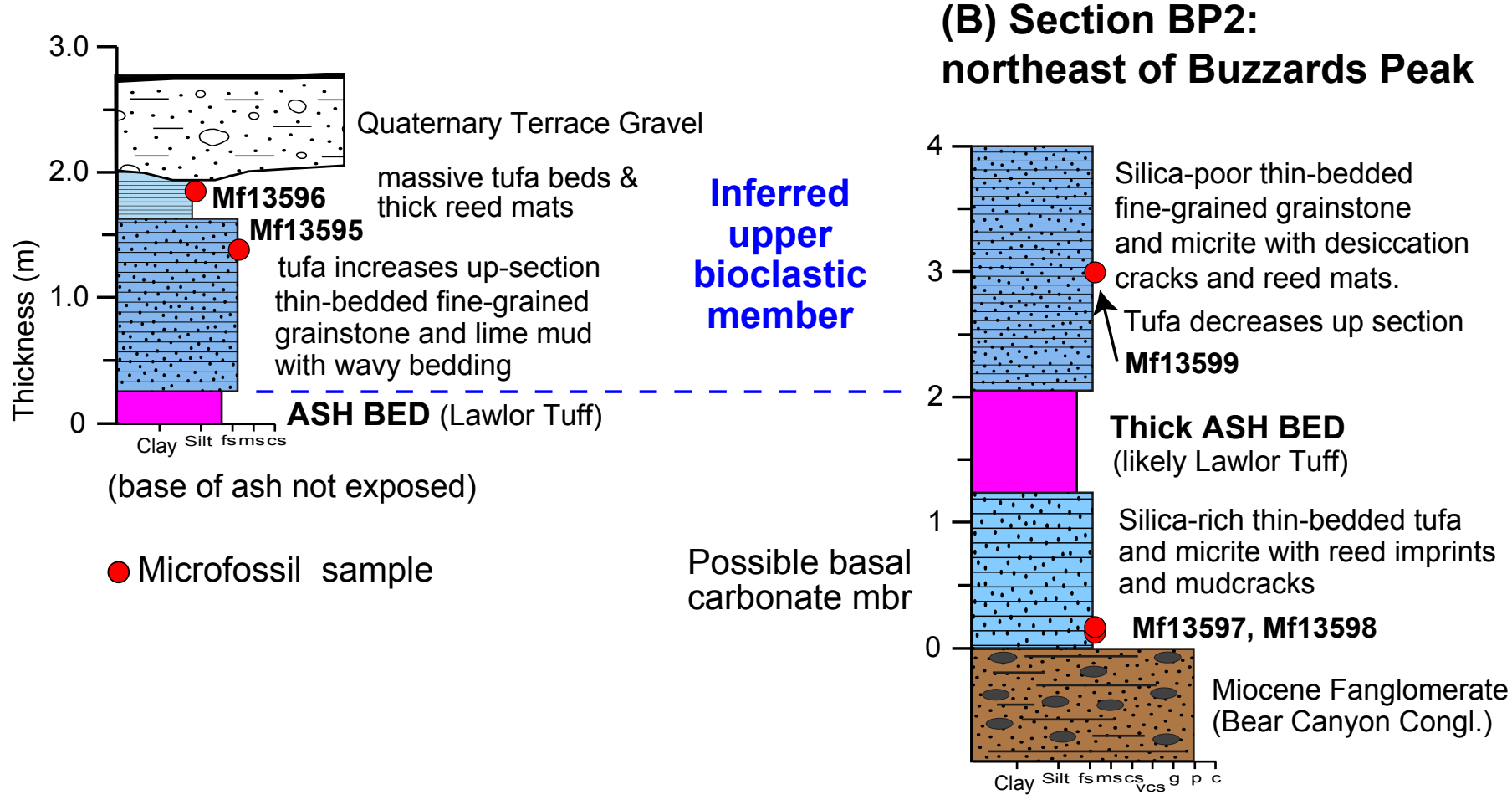

Figure 11 


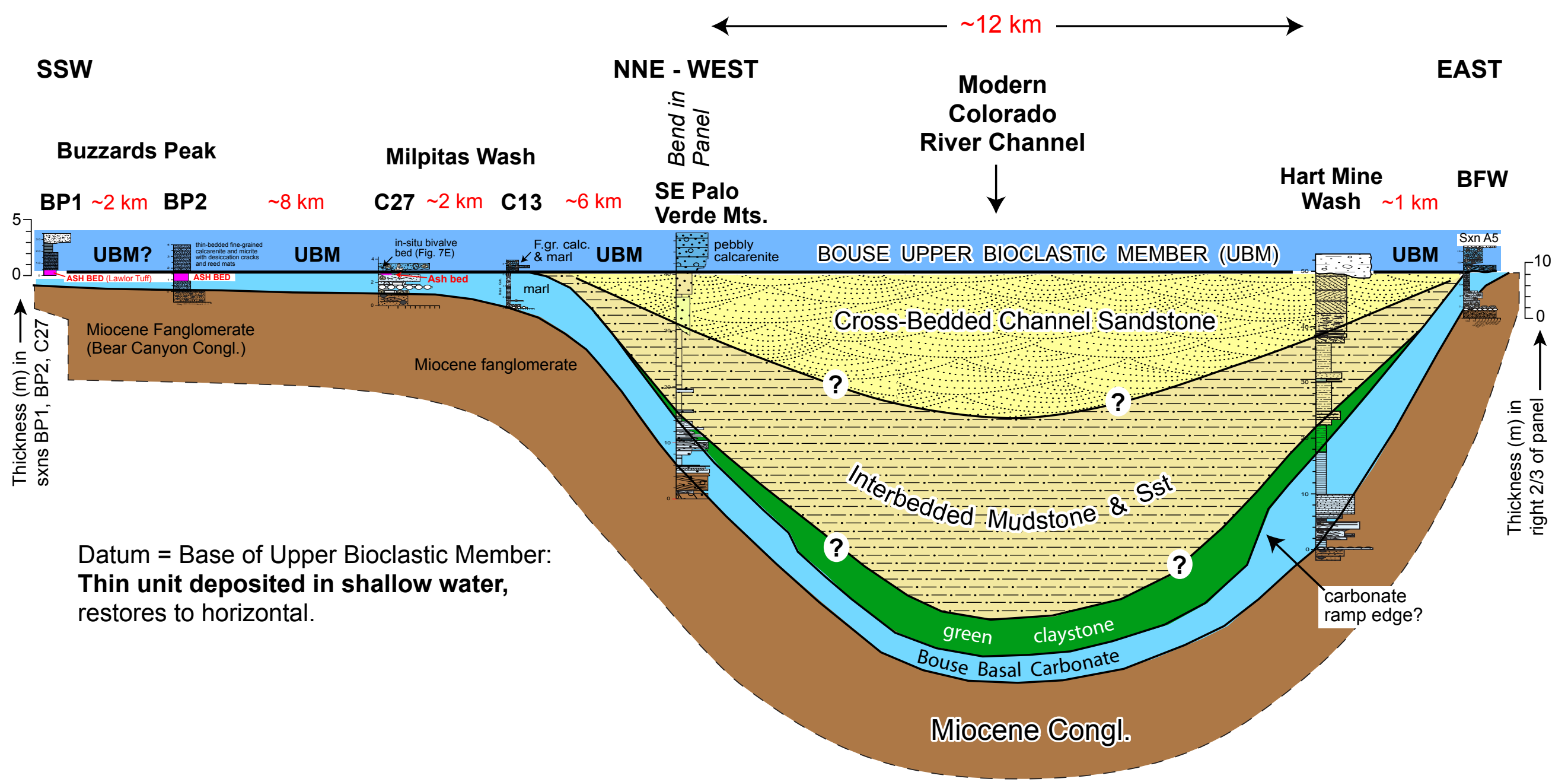

Figure 12 


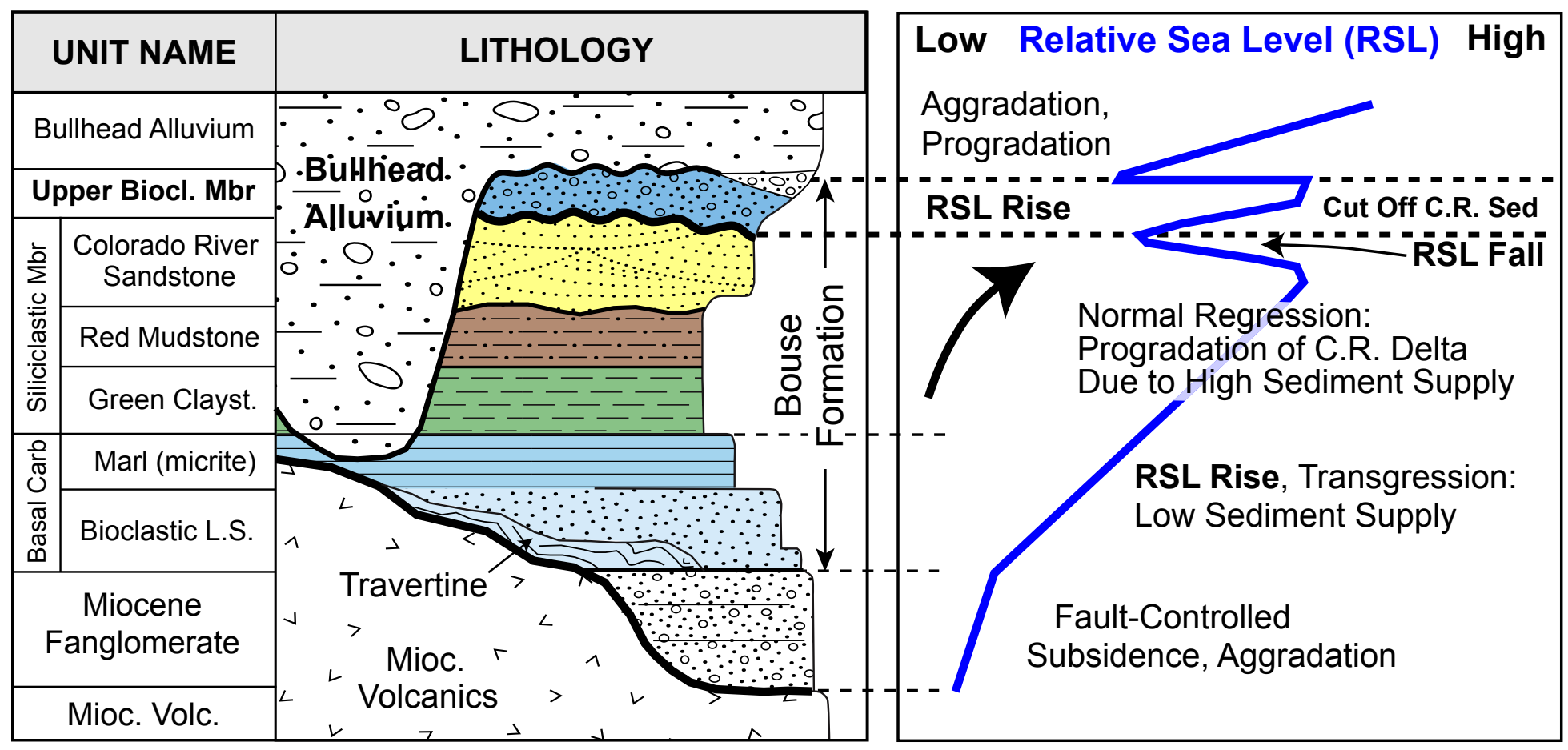

Figure 13 


\section{A. Bouse Basal Carbonate Member}

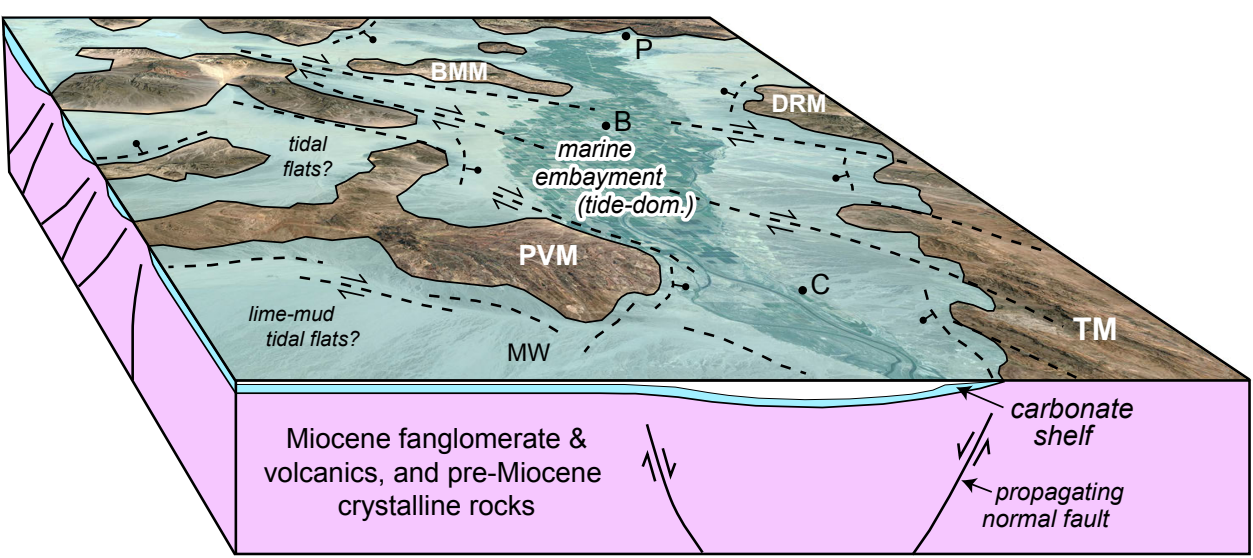

Tide-dominated marine embayment, pre-Colorado River

\section{Bouse Upper Bioclastic Member}

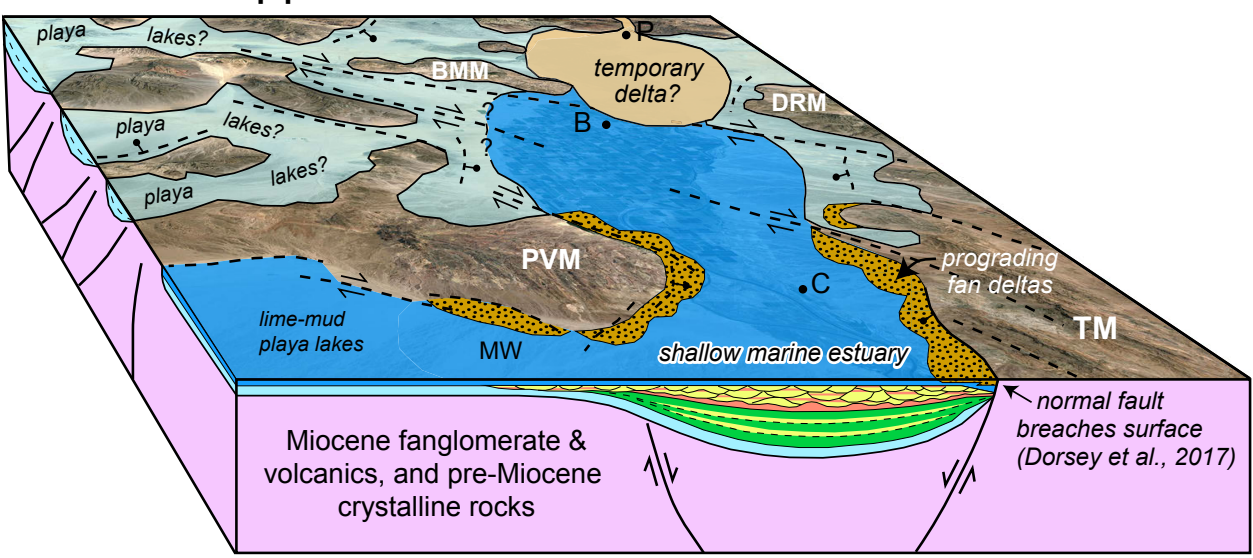

Re-flooding of lower C.R. valley by shallow marine waters

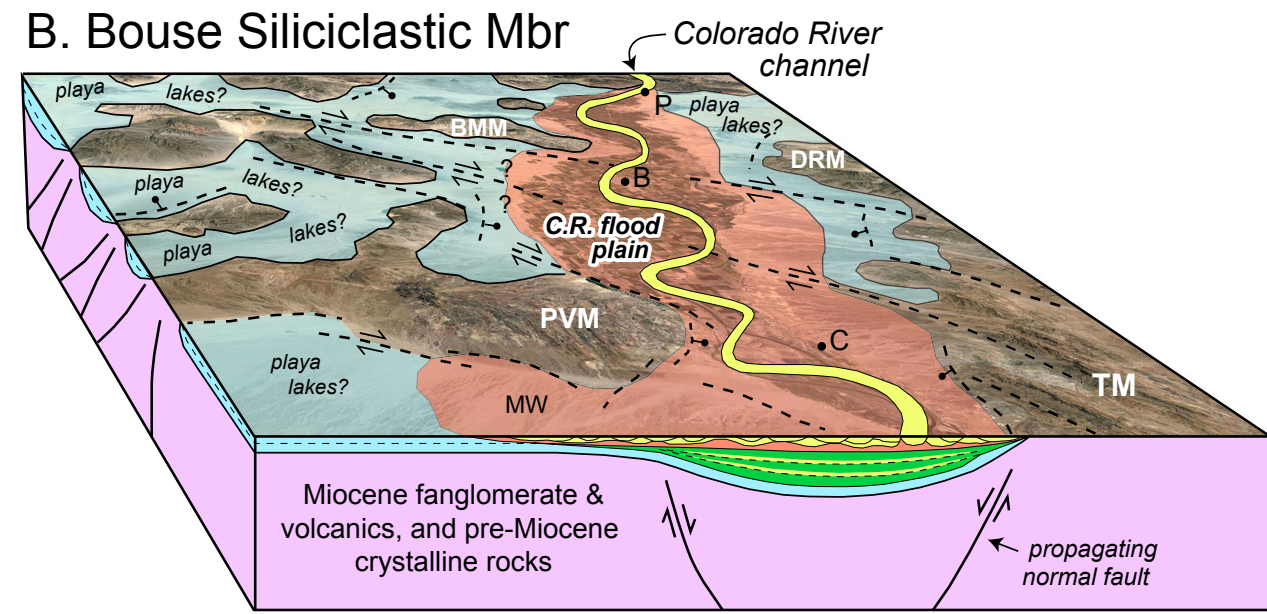

Arrival of Colorado River delta and through-flowing river

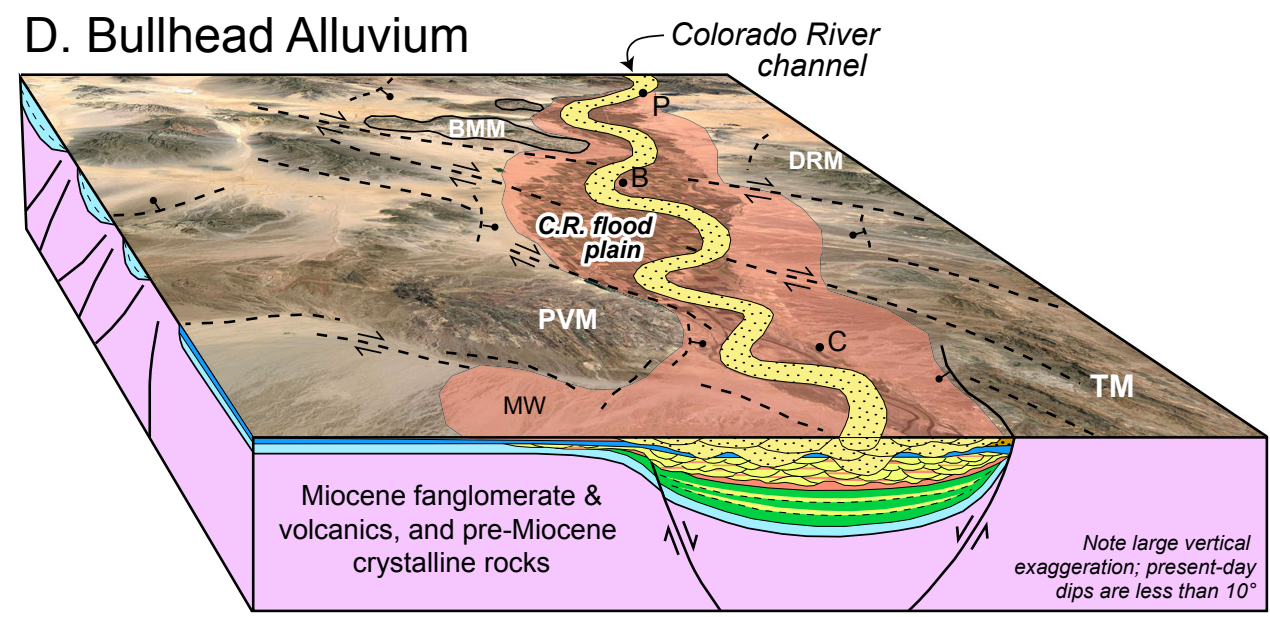

Resumption of through-flowing Colorado River

Figure 14. Interpretation of depositional environments and structural controls on the southern Bouse Formation. 

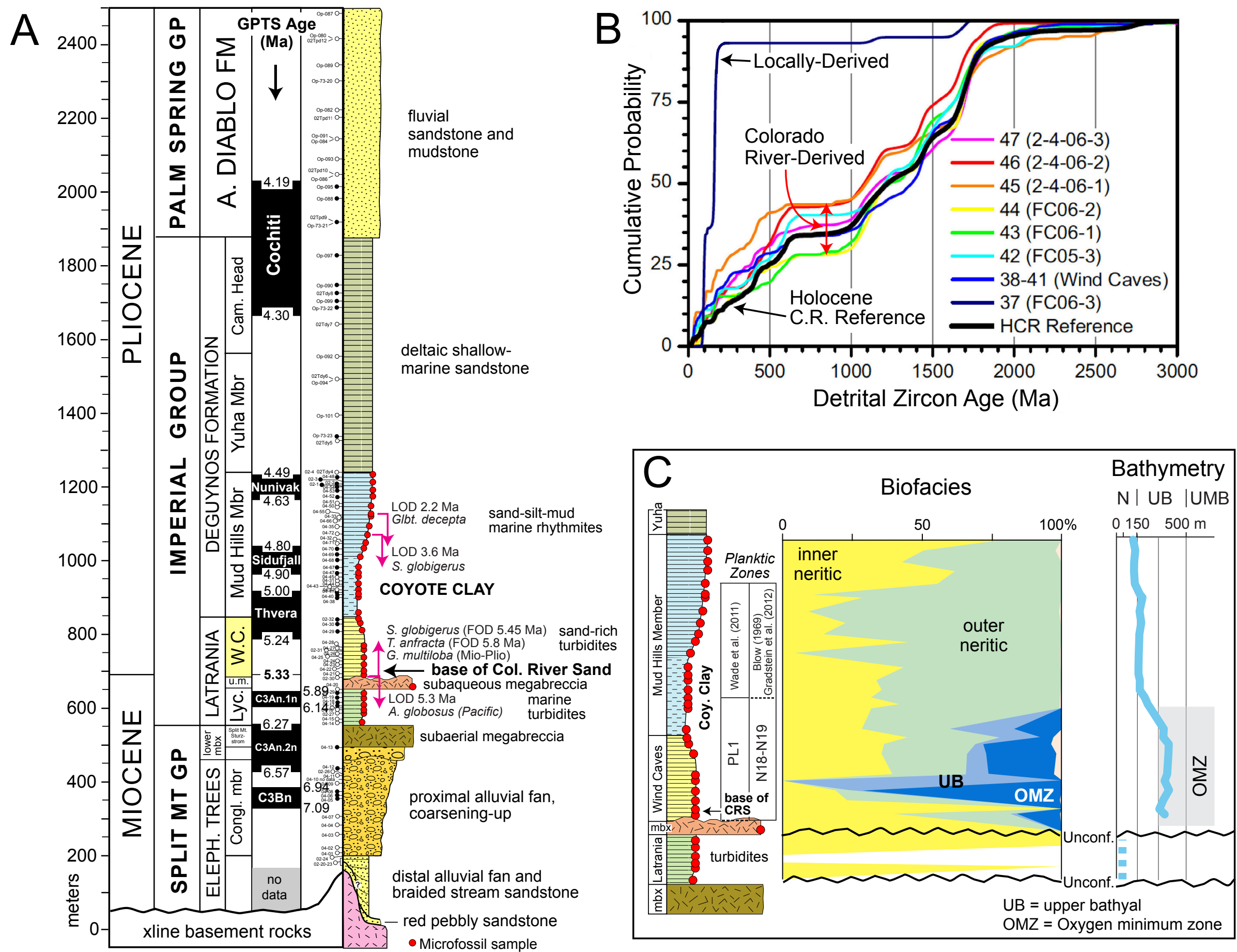

Figure 15 


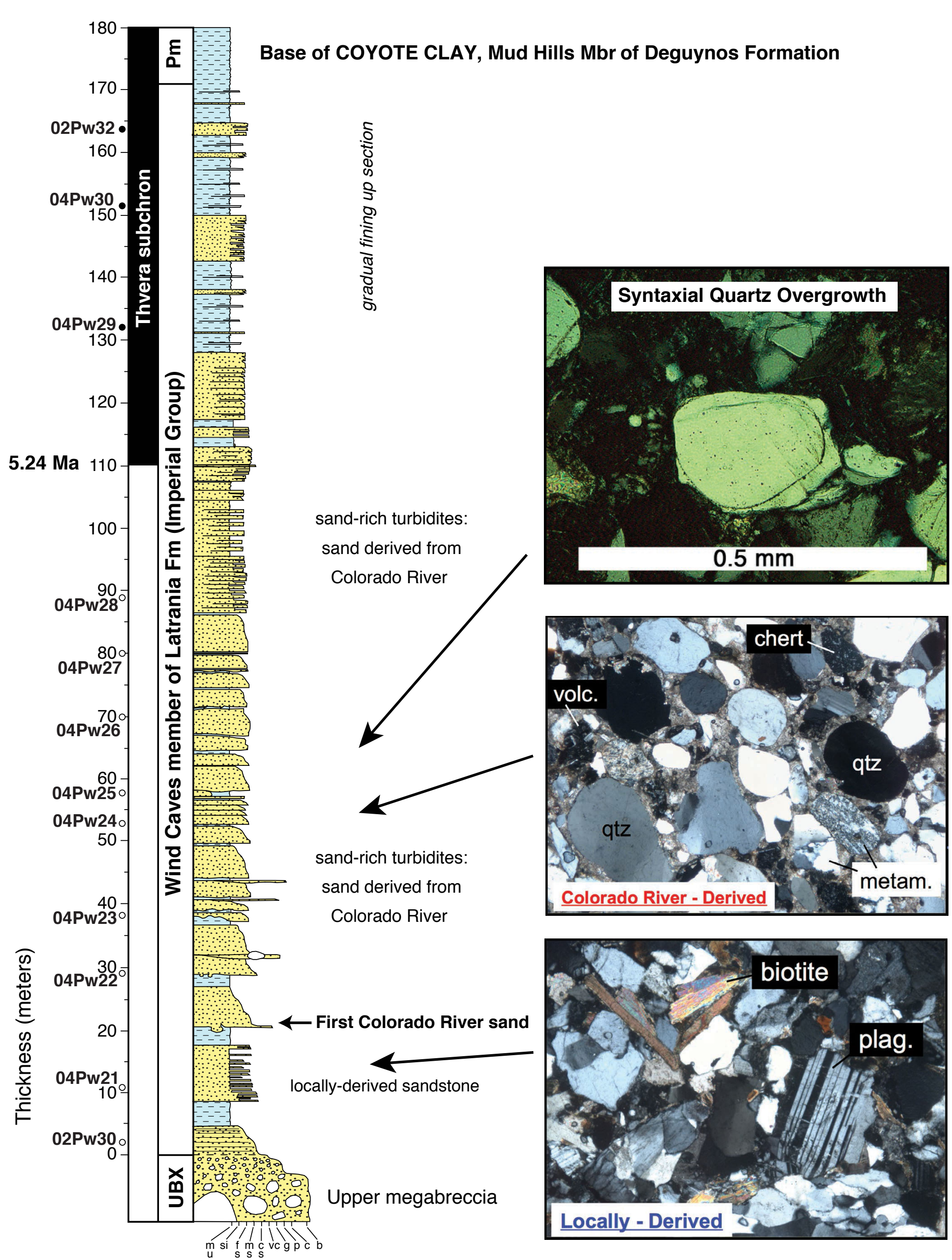

Figure 16 

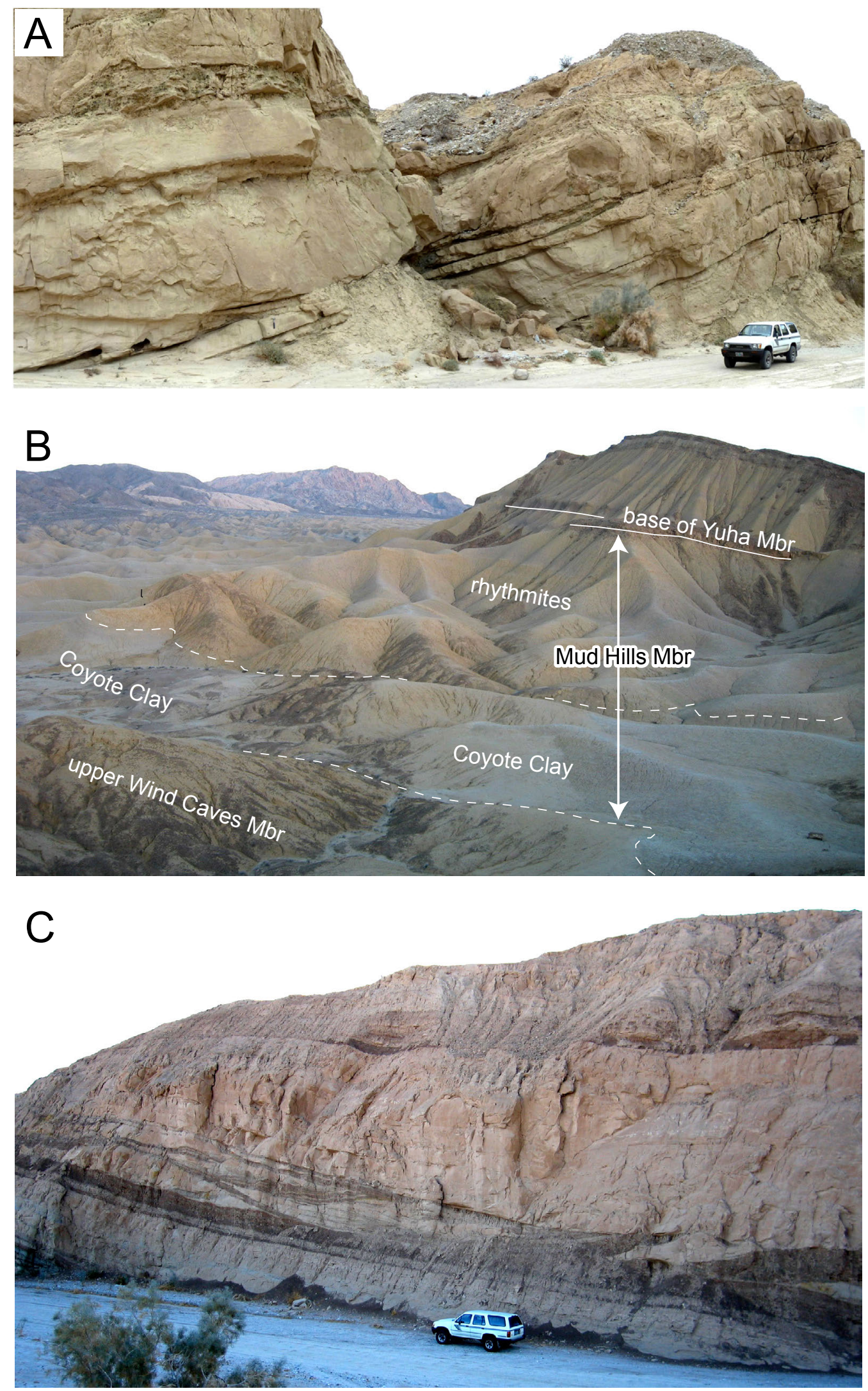

Figure 17. Field photos of sedimentary rocks in the Fish Creek - Vallectio basin. A. Channelized sand-rich turbidites in the Wind Caves member of the Latrania Formation. B. Gently dipping interval that includes the upper Wind Caves member, Coyote Clay unit of the Mud Hills member, and lower part of the Imperial Group marine deltaic succession. C. Large-scale cross-bedded Colorado River channel sandstones and overbank mudstones of the Arroyo Diablo Formation. 


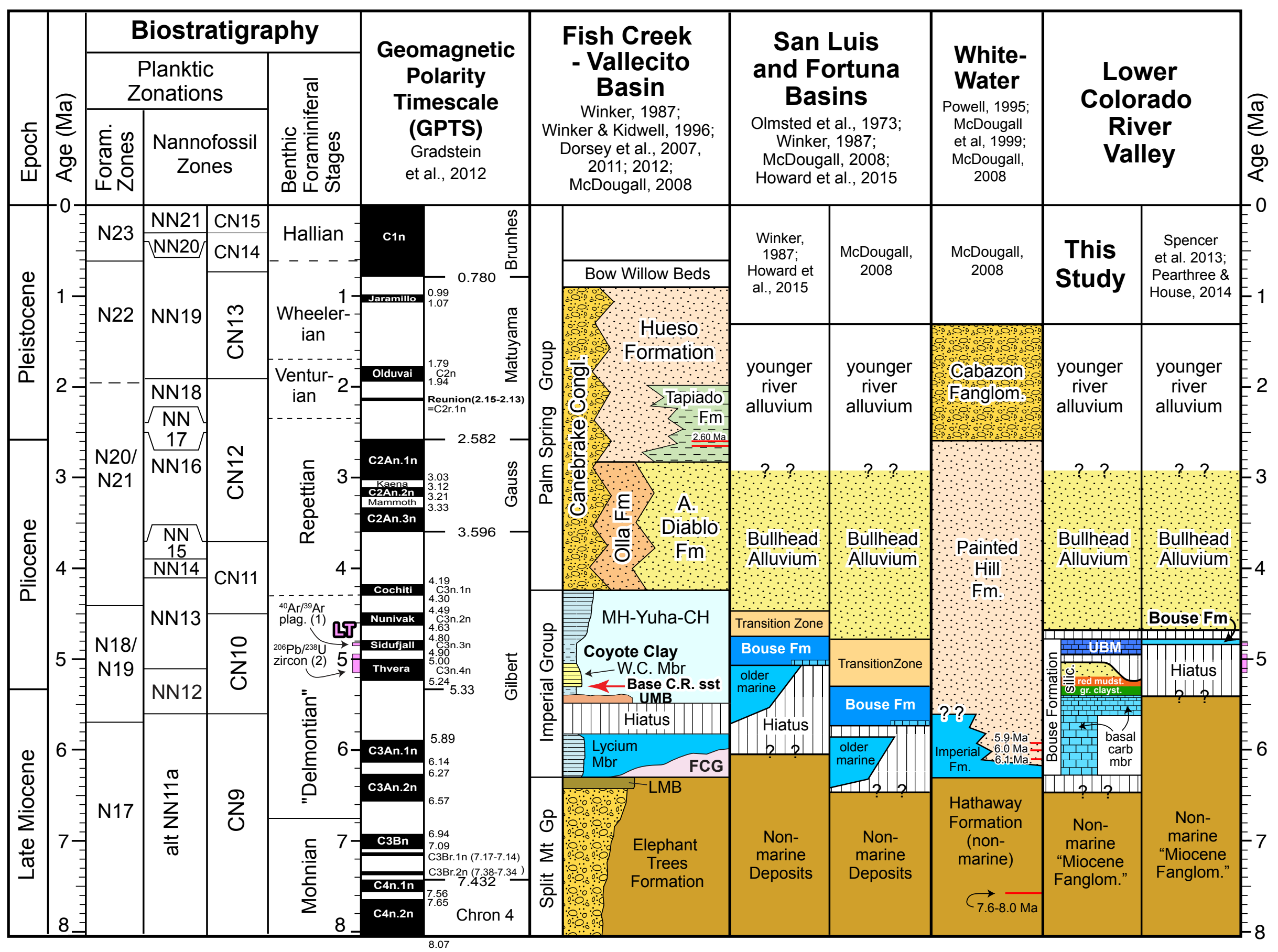

Figure 18 

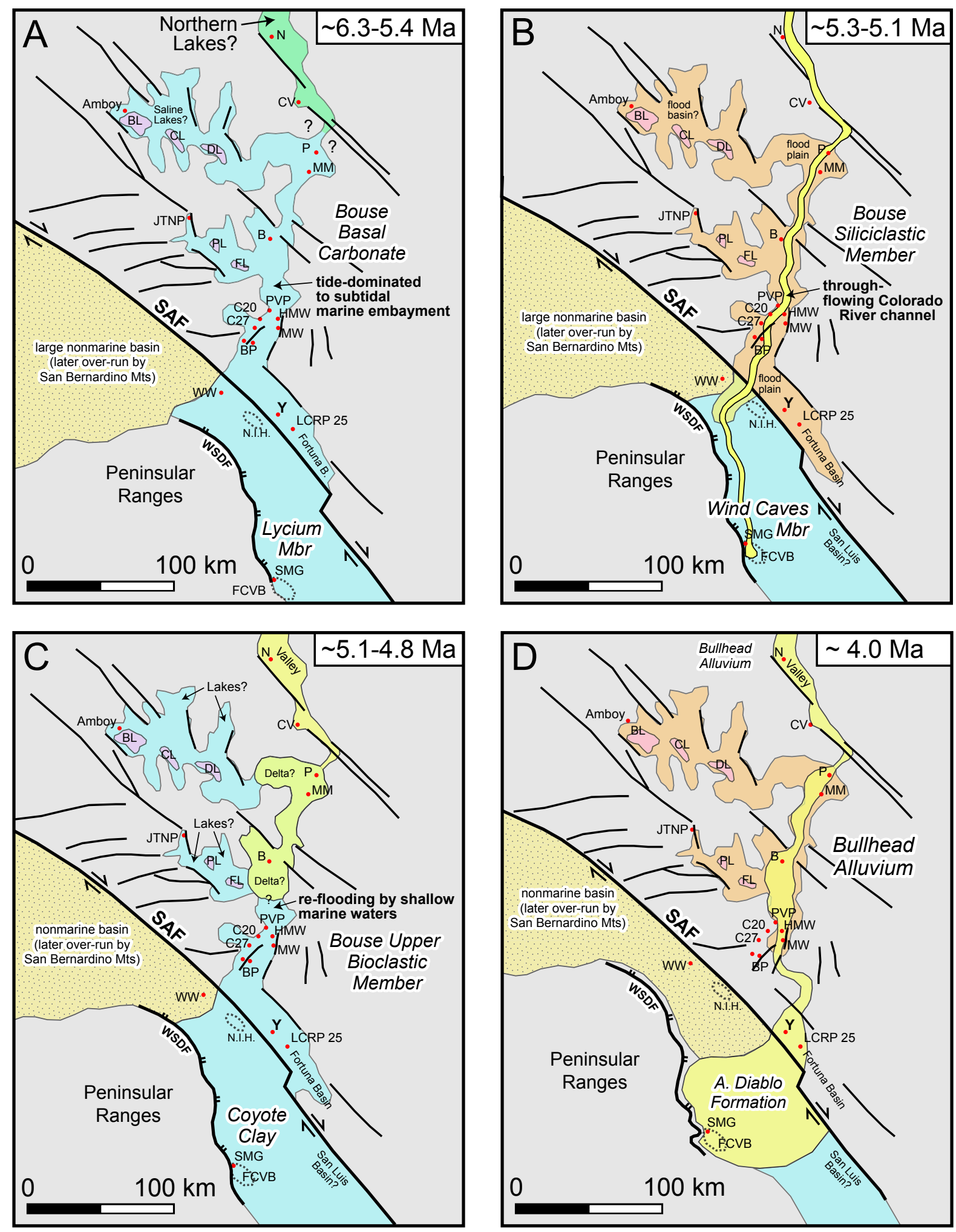

Figure 19 

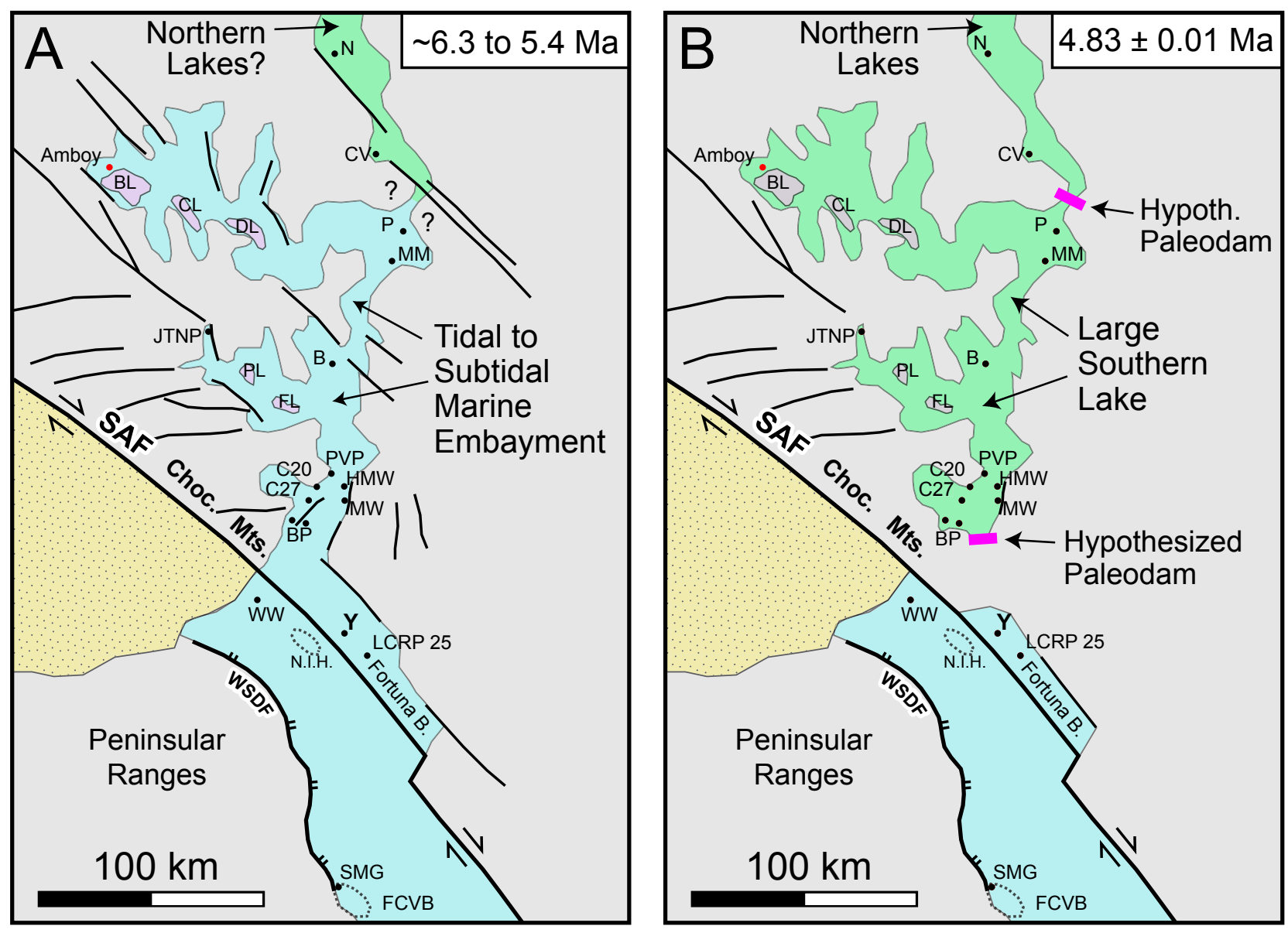

Figure 20 


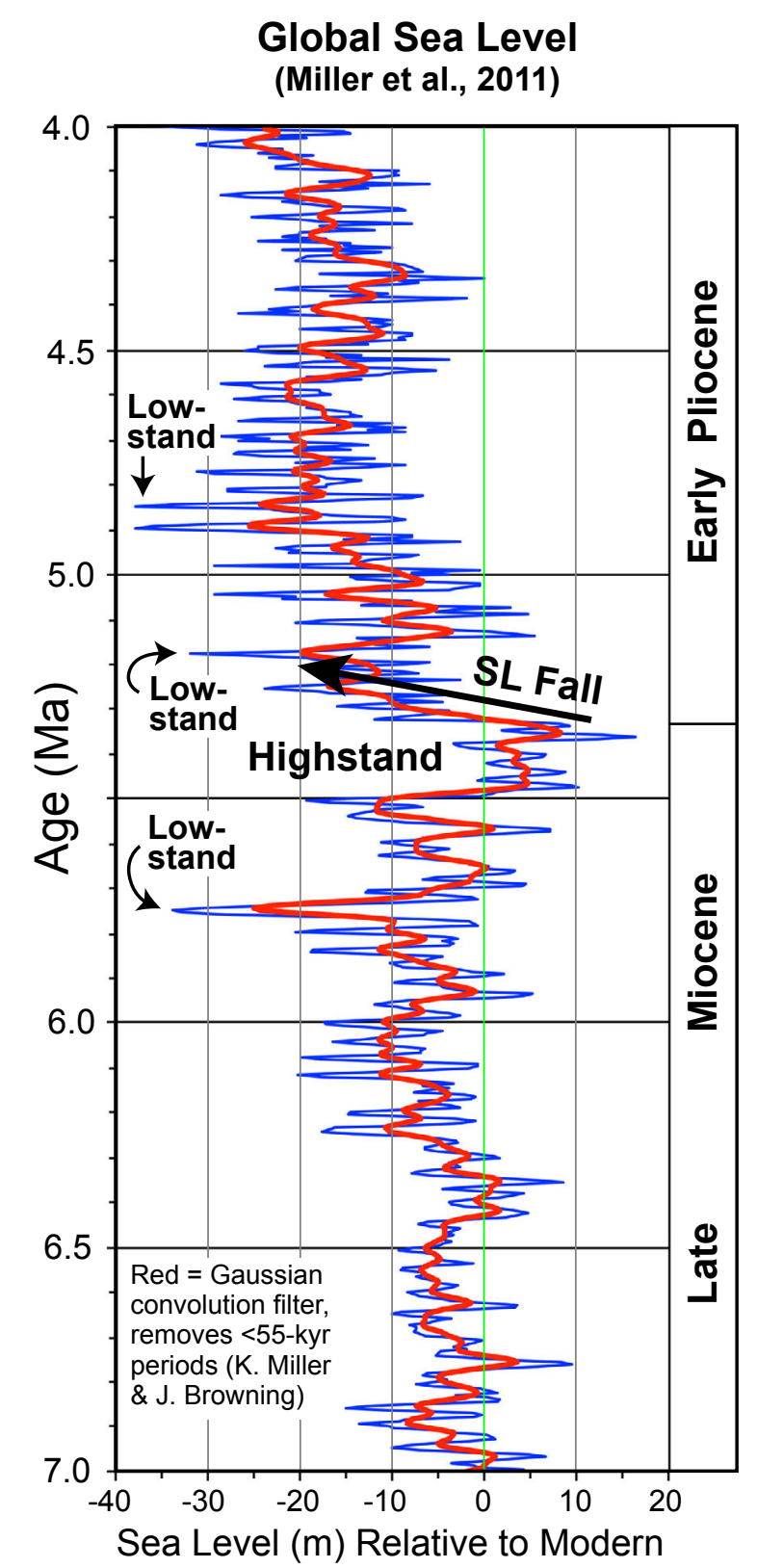

\section{Salton Trough \\ (Dorsey et al., 2011)}

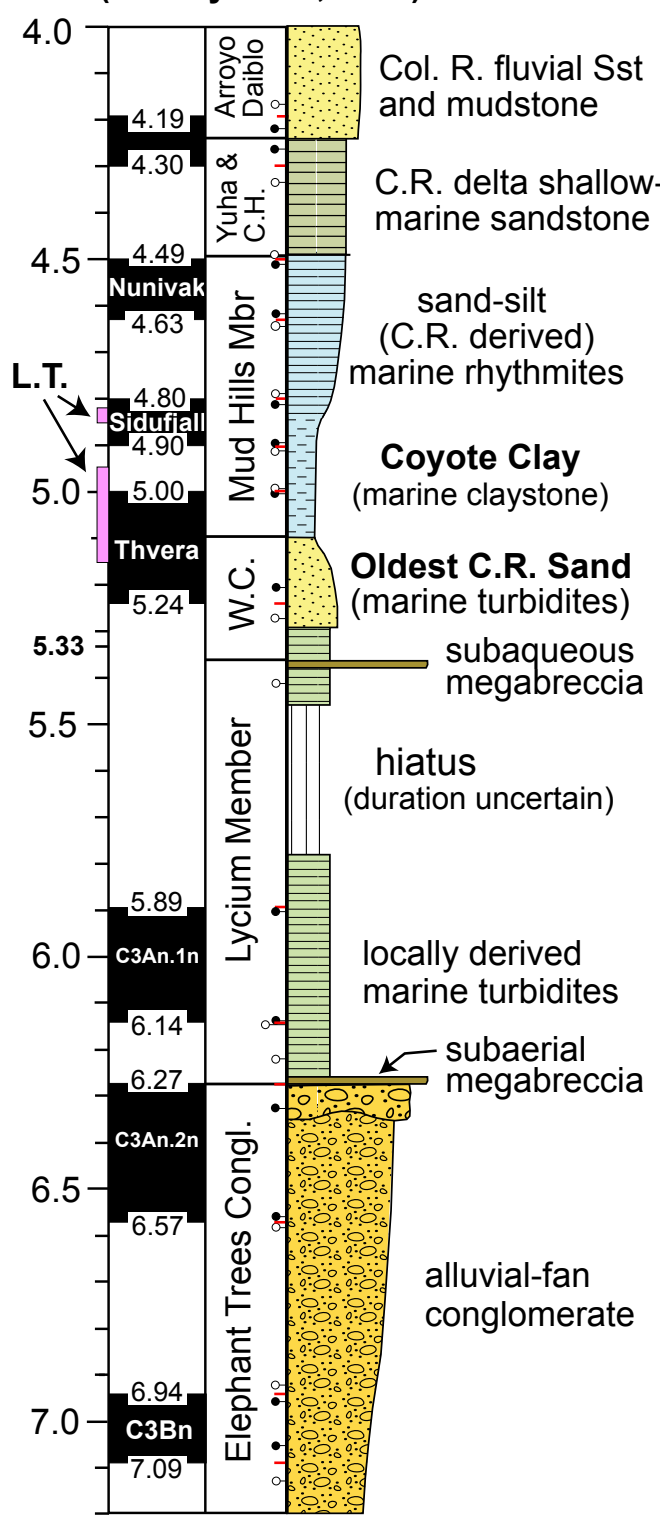

Lower Colorado River Valley (southern Bouse Fm; this study)

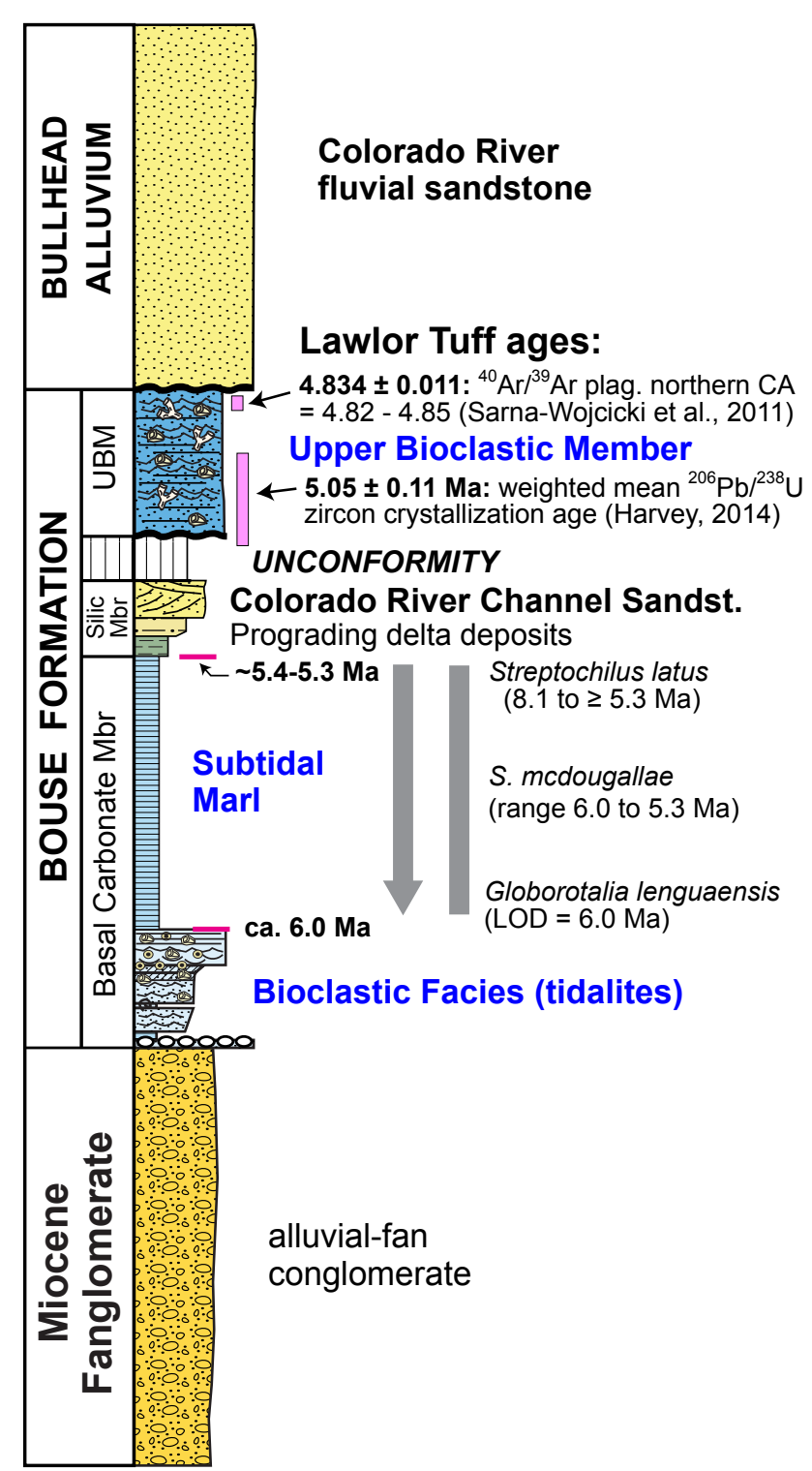

Figure 21 